\title{
Field Validation of Toxicity Tests to Evaluate the Potential for Beneficial Use of Produced Water
}

\author{
Final Scientific Report \\ Reporting Period Start Date: October 1, 2004 \\ Reporting Period End Date: June 30, 2008 \\ Principal Authors: Joseph R. Bidwell, Ph.D., Jonathan C. Fisher, \\ and Naomi L. Cooper \\ June 21, 2008 \\ Project \# DE-FC26-04NT15544
}

Submitting Organization: Department of Zoology, Oklahoma State University, 430

Life Sciences West, Stillwater, OK 74078, USA

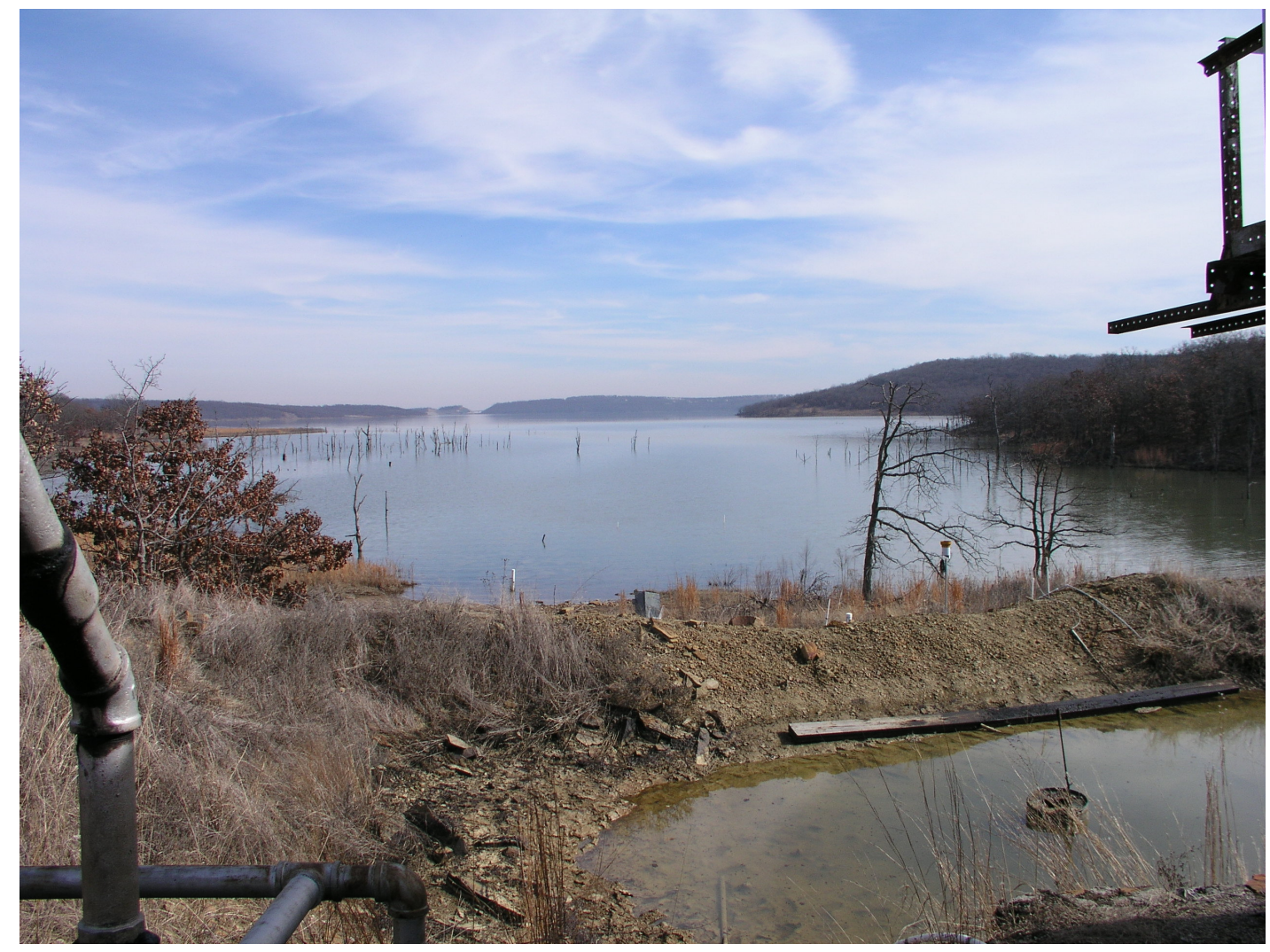




\section{Disclaimer}

The report was prepared as an account of work sponsored by an agency of the United States Government. Neither the United States Government nor any agency thereof, nor any of their employees, makes any warranty, express or implied, or assumes any legal liability or responsibility for the accuracy, completeness, or usefulness of any information, apparatus, product, or process disclosed, or represents, that its use would not infringe privately owned rights. Reference herein to any specific commercial product, process, or service by trade name, trademark, manufacturer, or otherwise does not necessarily constitute or imply its endorsement, recommendation, or favoring by the United States Government or any agency thereof. The views and opinions of authors expressed herein do not necessarily state or reflect those of the United States Government or any agency thereof. 


\section{Abstract}

This study investigated potential biological effects of produced water contamination derived from occasional surface overflow and possible subsurface intrusion at an oil production site along the shore of Skiatook Lake, Oklahoma. We monitored basic chemistry and acute toxicity to a suite of standard aquatic test species (fathead minnowPimephales promelas, Daphnia pulex, Daphnia magna, and Ceriodaphnia dubia) in produced water and in samples taken from shallow groundwater wells on the site. Toxicity identification evaluations and ion toxicity modeling were used to identify toxic constituents in the samples. Lake sediment at the oil production site and at a reference site were also analyzed for brine intrusion chemically and by testing sediment toxicity using the benthic invertebrates, Chironomus dilutus, and Hyallela azteca. Sediment quality was also assessed with in situ survival and growth studies with $\mathrm{H}$. azteca and the Asian clam, Corbicula fluminea, and by benthic macroinvertebrate community sampling.

The produced water was acutely toxic to the aquatic test organisms at concentrations ranging from $1 \%$ to $10 \%$ of the whole produced water sample. Toxicity identification evaluation and ion toxicity modeling indicated major ion salts and hydrocarbons were the primary mixture toxicants. The standardized test species used in the laboratory bioassays exhibited differences in sensitivity to these two general classes of contaminants, which underscores the importance of using multiple species when evaluating produced water toxicity. Toxicity of groundwater was greater in samples from wells near a produced water injection well and an evaporation pond. Principle component analyses (PCA) of chemical data derived from the groundwater wells indicated dilution by lake water and possible biogeochemical reactions as factors that ameliorated groundwater toxicity. Elevated concentrations of major ions were found in pore water from lake sediments, but toxicity from these ions was limited to sediment depths of $10 \mathrm{~cm}$ or greater, which is outside of the primary zone of biological activity. Further, exposure to site sediments did not have any effects on test organisms, and macroinvertebrate communities did not indicate impairment at the oil production site as compared to a reference site. In situ experiments with $\mathrm{H}$. azteca and $\mathrm{C}$. fluminea, indicated a sublethal site effect (on growth of both species), but these could not be definitively linked with produced water infiltration. Severe weather conditions (drought followed by flooding) negatively influenced the intensity of lake sampling aimed at delineating produced water infiltration.

Due to the lack of clear evidence of produced water infiltration into the sub-littoral zone of the lake, it was not possible to assess whether the laboratory bioassays of produced water effectively indicate risk in the receiving system. However, the acutely toxic nature of the produced water and general lack of biological effects in the lake at the oil production site suggest minimal to no produced water infiltration into surficial lake sediments and the near-shore water column. This study was able to demonstrate the utility of ion toxicity modeling to support data from toxicity identification evaluations aimed at identifying key toxic constituents in produced water. This information could be used to prioritize options for treating produced water in order to reduce toxic constituents and enhance options for reuse. The study also demonstrated how geographic information systems, toxicity modeling, and toxicity assessment could be used to facilitate future site assessments. 


\section{Table of Contents}

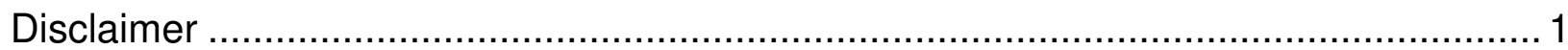

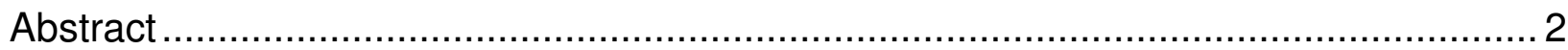

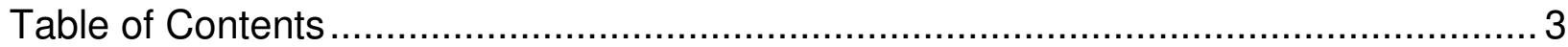

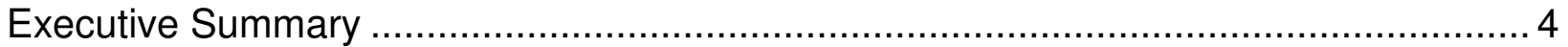

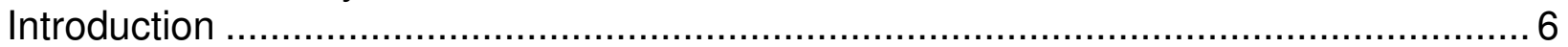

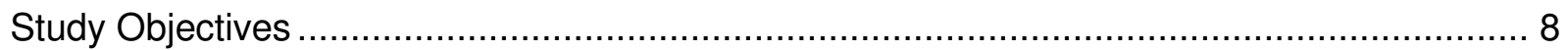

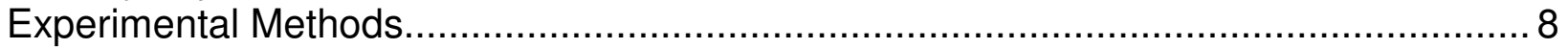

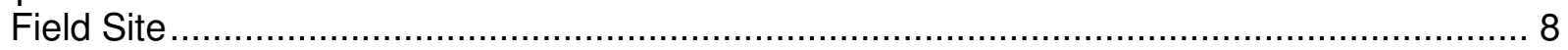

Phase 1 Research Activities...................................................................................... 9

Task 1.0-Definitive characterization of produced water infiltration into the receiving

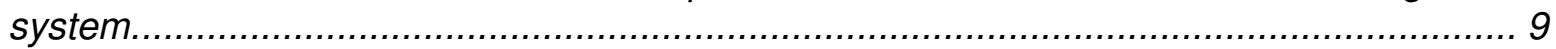

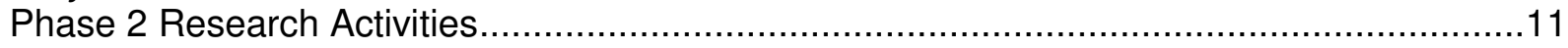

Task 1.0 - Routine laboratory toxicity testing of produced water and groundwater samples

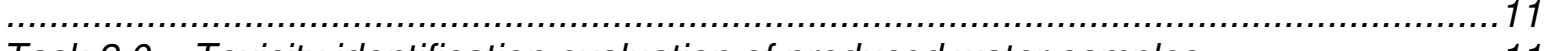

Task 2.0 - Toxicity identification evaluation of produced water samples ..........................11

Phase 3 Research Activities.................................................................................12

Task 1.0 - Assessment of benthic community condition...............................................12

Task 2.0 - In-situ bioassays ........................................................................ 12

Task 3.0 - Comparison of laboratory and field data................................................. 13

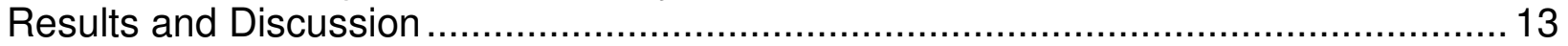

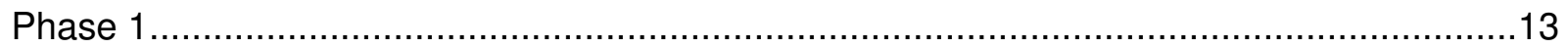

Task 1.0-Definitive characterization of produced water infiltration into the receiving system .......................................................................................................... 13

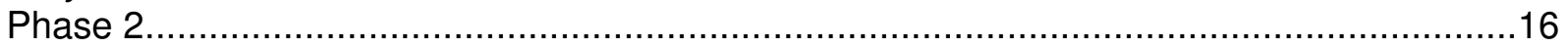

Task 1.0 - Routine laboratory toxicity testing of produced water and groundwater samples

Task 2.0 - Toxicity identification evaluation of produced water samples .........................18

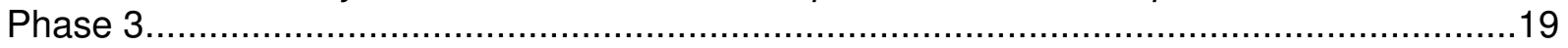

Task 1.0 - Assessment of benthic community condition.............................................19

Task 2.0 - Sediment bioassays and In-situ studies ......................................................20

Task 3.0 - Comparison of laboratory and field data................................................22

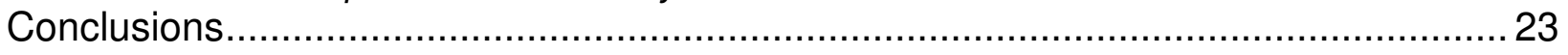

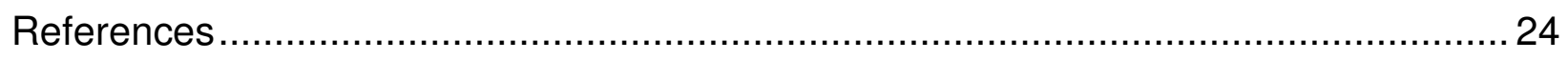

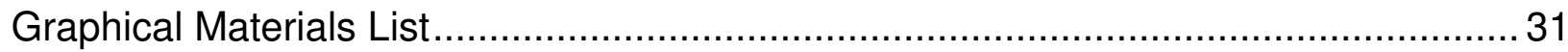

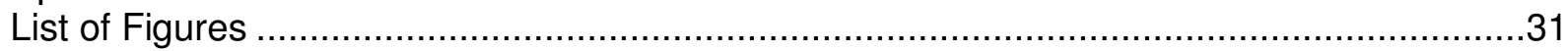

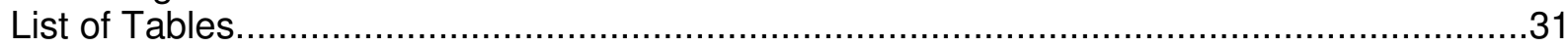

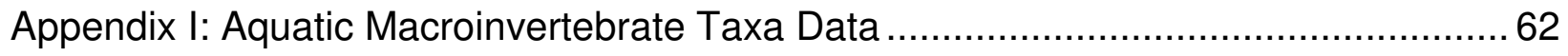

Project \# DE-FC26-04NT15544-Final Report 3 


\section{Executive Summary}

A major issue facing oil and gas producers at inland production sites is the disposal of produced water that co-occurs with the oil or gas deposit. In addition to high levels of dissolved salts, produced water may contain dissolved and free-phase hydrocarbons, trace metals, and radionuclides, all of which could have an impact on surface and groundwater quality if discharged directly into the environment. Disposal of produced water in inland areas is accomplished through re-injection, release into holding ponds, commercial hauling and treatment, or reuse. Of these, evaporation from holding ponds and/or re-injection are the more commonly-used methods of disposal, although "beneficial use" of produced water for applications such as aquifer recharge, and wetland remediation has been viewed as a promising alternative. Costs of beneficial use are usually associated with the degree of treatment required to remove potential contaminants from the produced water. In this regard, aquatic toxicity studies of produced water can assist in identifying key constituents that would need to be treated before beneficial use or release into the environment. In addition, comparison of results from laboratory bioassays with field assessments of aquatic systems that have been subject to produced water input can help validate how well laboratory data indicate the risk of impact associated with the release of produced water.

This study was conducted at Skiatook Lake, a 10,500-acre impoundment in Osage County, Oklahoma. Osage County ranks among the top oil and gas producing areas in the state, with some 38,000 oil wells. Of these, about 13,000 wells lie within the Skiatook Lake watershed (about $820 \mathrm{~km}^{2}$ ). In many instances, wells occur within a few tens of meters of the lake shoreline or the banks of streams that feed into the system. The produced waters derived from these wells are normally reinjected into underlying formations for disposal. However, inadvertent spills, leaks, and accidents, have lead to both historic and present release of produced water in the riparian zone and into the lake. The actual field site used in the study was one of the focal points of the U.S. Geological Survey's (USGS) Osage-Skiatook Petroleum Environmental Research (OSPER) Project. Active oil production has been ongoing at the site from the late 1930's to the present. Previous USGS studies at the site have indicated salt scarring from surface flow of produced water and subsurface transport of produced water salts and hydrocarbons from at least three locations; an old tank battery, an injection well, tank, and pit, and a large active tank battery and associated pit. The USGS data also indicate that highly saline produced water has been seeping from the active pit and flows toward the lake. As such, the field site provided a unique opportunity to evaluate the toxicity of produced water taken directly from on-site storage tanks and to conduct studies in the lake to determine what impacts produced water infiltration may have been having on the system. The specific objectives of the project were to characterize the zone of produced water infiltration in the lake, evaluate toxicity of the produced water using laboratory bioassays along with toxicity identification and evaluation (TIE) to indicate toxic constituents of produced water, and determine the effects of produced water intrusion on benthic macroinvertebrate communities using field sampling and in situ experiments. During the course of the study, the USGS had a tacit agreement with United States Environmental Protection Agency Region 6 to not take substantial enforcement action at this site while the research project was ongoing. 
Site produced water was acutely toxic to aquatic test organisms (fathead minnows- Pimephales promelas, Daphnia pulex, Daphnia magna, and Ceriodaphnia dubia) at concentrations ranging from $1 \%$ to $10 \%$ of the whole produced water sample. As determined by toxicity identification evaluation and associated ion toxicity modeling, major ion salts and hydrocarbons were the primary mixture toxicants, and the salts were found to contaminate groundwater across the entire site. The standardized test species used in the laboratory bioassays (fathead minnows and daphnids) exhibited differences in sensitivity to these two general classes of contaminants, which underscores the importance of using multiple species when evaluating produced water toxicity.

A series of sampling wells drilled by the USGS researchers were used to collect groundwater samples and groundwater toxicity varied greatly between these wells ( $\mathrm{LC}_{50}$ 's ranged from $2.12 \%$ to over $100 \%$ ). Samples from wells closest to the produced water injection site exhibited the greatest toxicity and water from wells located on a salt scar derived from the evaporation pond had toxicity greater than that from wells located in a vegetated area. These data suggest that contamination from both the injection well and evaporation pond contributed to measured groundwater effects. Toxicity modeling of groundwater ion profiles indicated the produced water injection well was probably the most significant contributor to groundwater toxicity. The use of geographic information system (GIS) model surfaces facilitated study of produced water plume and may have similar application at other contaminated oil production sites in which elevated ions are the primary source of effects. In addition, principle component analyses (PCA) of chemical data derived from the groundwater wells proved useful for indicating dilution by lake water and biogeochemical reactions as possible factors that ameliorated groundwater toxicity.

Elevated concentrations of major ions were found in pore water from lake sediments, but toxicity from these ions appears limited to sediment depths of $10 \mathrm{~cm}$ or greater, which is outside of the primary zone of biological activity. Further, exposure to site sediments did not have any effects on test organisms (Chironomus dilutus and Hyallela azteca) during laboratory toxicity testing and macroinvertebrate communities did not indicate impairment at the oil production site as compared to a reference site. In situ experiments with $\mathrm{H}$. azteca and the Asian clam, Corbicula fluminea, did indicate a sublethal site effect (on growth of both species), but these could not be definitively linked with produced water infiltration. Our ability to characterize produced water infiltration into the lake was also influenced by extreme weather conditions during the study (a severe drought in 2006 and record flooding in 2007) which significantly reduced the amount of field sampling that could be undertaken.

Due to the lack of clear evidence of produced water infiltration into the sub-littoral zone of the lake, it was not possible to assess whether the laboratory bioassays of produced water effectively indicate risk in the receiving system. However, the acutely toxic nature of the produced water and general lack of biological effects in the lake at the oil production site indicate the degree of produced water infiltration into surficial lake sediments and the near-shore water column is not very extensive. This study demonstrated the utility of ion toxicity modeling to help identify key toxic constituents in produced water and further illustrated how geographic information system (GIS), toxicity modeling, and toxicity assessment could be used to facilitate future site assessments. 


\section{Introduction}

A major issue facing oil and gas producers in both offshore and inland facilities is the disposal of produced water that is pumped to the surface along with the fossil fuels. In addition to high levels of dissolved salts, produced water may contain dissolved and free-phase hydrocarbons, trace metals, and radionuclides, all of which could have a significant impact on surface and groundwater quality (Boelter et al. 1992). Generally, the volume of produced water increases as a well ages and may be as great as $98 \%$ of the total volume of extracted fluids (Stephenson, 1992). On average, produced water accounts for approximately $80 \%$ of the residual waste associated with oil and gas production that requires some type of management or disposal, and concerns regarding the environmental effects and disposal of this waste have been reported from as early as the 1920's (Wiebe et al., 1924; Clemens and Jones, 1954). The volume of produced water that must be dealt with is far from trivial, with an estimated 18 billion barrels generated by U.S. onshore wells in 1995 alone (Veil, 2003).

Disposal of produced water in inland areas is accomplished through reinjection, release into holding ponds or surface waters, commercial hauling and treatment, or reuse. Cost estimates for deep well injection of produced water range from $\$ 0.50$ to $\$ 1.75 / \mathrm{barrel}$, while commercial hauling and treatment costs may exceed $\$ 5.00 / \mathrm{barrel}$ (Jackson and Meyers 2002). Beneficial reuse options include livestock and wildlife watering, aquaculture, aquifer recharge and wetland remediation (for selected reviews, see GWPC 2002). The costs of produced water reuse are largely associated with the degree of treatment required to remove potential contaminants, with the extent of treatment depending on the overall quality of the water (ALL Consulting 2003).

Numerous technologies exist either to prevent produced water production through downhole separation (separates oil and water at bottom of a production well before water is brought to the surface, Veil et al. 1999) or to remove organic contaminants via photodegradation (Moraes et al. 2004) or microorganism induced degradation (Woolard and Irvine 1995; Dalmacija et al. 1996). Even if hydrocarbons are removed at the surface, the brine can still negatively affect receiving water communities (Kefford 2000). Desalinization of brines is a viable, but potentially expensive solution for beneficial reuse of produced water. Evaporation allows reclamation of salts from produced water, which have been used by local highway departments in New York for deicing (Atkinson et al. 1992). Produced water was found to be unsuitable for irrigation in Wyoming due to a buildup of salts in the root zone (Ganjegunte et al. 2005). Beneficial reuse of produced waters is likely limited by the multiple contaminants present and the presence of certain contaminants (such as nonessential or heavy metals or radionucleotides) that would completely preclude most potential reuses.

For onshore locations, release of produced water for any beneficial purpose is largely regulated at the state level, and quality assessment is based on the degree to which the water meets single chemical water quality standards or passes prescribed toxicity assessments in accordance with the National Pollutant Discharge Elimination System (NPDES) permitting program (Mancini and Stilwell, 1992; ALL Consulting 2003, see also US Code of Federal Regulations, 40 CFR Part 435). Approaches that assess the quality of produced water therefore have important implications for the particular treatment regime, associated treatment costs, and ultimate potential for beneficial use. 
Toxicity assessments for both freshwater and marine systems involve the use of selected "standard" test species that are exposed to dilutions of the material being evaluated (e.g. produced water), with the response of the organisms determined through the use of either lethal (mortality) and/or sublethal (growth/reproduction) endpoints. While these standard laboratory tests represent the most common method currently used to evaluate the potential toxicity of aqueous wastes, the extent to which test results represent actual conditions in the field has been questioned, and the need for field validation of tests has been identified (Cairns et al. 1996).

In the case of toxicity evaluations of produced water, constituents that may negatively affect an organism in the relatively sterile environment of a laboratory test beaker may be effectively detoxified in a field setting. For example, dissolved solids may be diluted by water flow in receiving systems, while organic constituents may adsorb to suspended material in the water column and be rendered unavailable for uptake by aquatic organisms. To date, toxicity assessment of produced water and associated field validation of laboratory test results has largely focused on offshore production in marine systems (e.g. Mendelssohn et al. 1990; Henderson et al. 1999; Washburn et al. 1999). While laboratory evaluations of marine produced water toxicity have indicated the potential for detrimental effects of untreated water (Krause 1995), a number of field validations have suggested that effects are significantly minimized when the produced water is subject to the diluting effects of the environment. For example, Mendelsshon et al. (1990) observed no effects of produced water discharges on marsh vegetation in freshwater and brackish wetlands in Louisiana, an effect they attributed to dilution and the behavior of the more dense produced water in the receiving system. Reed et al. (1994) observed that in-field effects of produced water on giant kelp were limited to sites within $5 \mathrm{~m}$ of the outfall even though laboratory test results indicated likely effects at sites farther afield. Douglas and Veil (1996) stated that produced water toxicity tests that focus on marine environments must be interpreted in light of the potential modification of the waste once it is discharged to the receiving system.

Unfortunately, relatively few studies have evaluated how well toxicity tests predict produced water effects in freshwater environments. This is significant, since the majority of the 37 U.S. states that are engaged in oil and gas production are landlocked (Produced Waters Database, 2002), meaning that 1) the potential for beneficial reuse will be greatest in these inland areas and 2) operators who wish to release produced water for beneficial reuse would be subject to discharge permit requirements that may include toxicity assessments with freshwater species.

Of those studies that have assessed the effects of produced water on freshwater organisms, elevated ion concentrations, organics and ammonia have been identified as the primary constituents causing observed toxicity (Ho and Caudle 1997; Sauer et al. 1997), and each of these components could be significantly modified upon entering a receiving system. However, field studies that validate these laboratory-based effects are practically nonexistent. In one combined laboratory and field investigation of produced water generated from an oil and gas field in Wyoming, the majority of field sites that were influenced by produced water releases were able to support functional biological communities, indicating the beneficial use of the produced water was appropriate (Mancini and Stilwell, 1992; Ramirez, 1993). 
Given the growing interest in reuse of produced water and the associated increase in toxicity assessments that will accompany its release, it is imperative to generate field data that will evaluate how well laboratory bioassays of produced water represent the true potential for environmental effects and whether existing discharge standards are appropriate. The present study sought to first use standard laboratory bioassays to evaluate the aquatic toxicity of produced water from an oil field production site located along the shoreline of a freshwater reservoir in Oklahoma, including the identification of key constituents in the produced water that was associated with any observed toxicity. Since previous studies by the United States Geological Survey (USGS) indicated produced water was entering the reservoir littoral zone through both occasional surface flow and potential subsurface infiltration, the second major objective was to determine if there were any apparent effects on organisms in the field, and if these effects were consistent with the results of laboratory bioassays with the produced water itself.

\section{Study Objectives}

1. Characterize the zone of produced water infiltration through chemical analyses on the sediment from the littoral and sublittoral zone of the lake.

2. Evaluate the potential for effects and temporal changes in produced water quality using laboratory bioassays along with toxicity identification and evaluation (TIE) to indicate toxic constituents of produced water.

3. Determine the effects of produced water intrusion on benthic macroinvertebrate communities using field sampling and in situ experiments.

4. Evaluate how representative laboratory toxicity tests are of field conditions.

\section{Experimental Methods}

Field Site

The field site for this study was located at Skiatook Lake, a 10,500-acre impoundment in Osage County, Oklahoma. Osage County ranks among the top oil and gas producing areas in the state, with some 38,000 oil wells. Of these, about 13,000 wells lie within the Skiatook Lake watershed (about $820 \mathrm{~km}^{2}$ ). In many instances, wells occur within a few tens of meters of the lake shoreline or the banks of streams that feed into the system. The produced waters derived from these wells are normally reinjected into underlying formations for disposal. However, inadvertent spills, leaks, and accidents, have lead to both historic and present release of produced water in the riparian zone and into the lake.

The field site itself was one of the focal points of the U.S. Geological Survey's Osage-Skiatook Petroleum Environmental Research (OSPER) Project and was designated "OSPER Site B" (Figure 1, also see project summary as described on the USGS Toxics Hydrology Program Homepage, http://ok.water.usgs.gov/skiatook/).

For the purposes of this study, the OSPER site will be referred to as the "oil production site" or "production site". Both the oil production site and the associated field 
reference site were located along the southern side of the lake on land contained within the grounds of the Zink Ranch. Oil production at the production site began in 1938, which predates lake impoundment in 1984.

Previous USGS studies at the site have indicated salt scarring from surface flow of produced water and subsurface transport of produced water salts and hydrocarbons from at least three locations; an old tank battery, an injection well, tank, and pit, and a large active tank battery and associated pit (Figure 2). The USGS data also indicate that highly saline produced water has been seeping from the active pit and flows toward the lake in the 1.2-1.5 meter thick layer of subsurface colluvium and alluvium and penetrates less than $1 \mathrm{~m}$ into the underlying impermeable shale. Modeling suggests that the produced water takes about 2-4 years to reach the lake through the mixed colluvium and alluvium. During the course of the study, the USGS had a tacit agreement with United States Environmental Protection Agency Region 6 to not take substantial enforcement action at this site while the research project was ongoing.

The water chemistry of the lake as a whole suggests that the system is not substantially contaminated by produced water from oil production sites. However, a reconnaissance survey of a number of tributary streams in the watershed under lowflow conditions conducted by the Osage Nation Environmental and Natural Resources Department shows that several streams draining into the lake have elevated salinity derived from oil production activities (see http://www.osagetribe.com/, Programs, Community Services, Osage Nation Environmental \& Natural Resources Department). The OSPER Site B was considered an ideal site to undertake the field component of this study because the sources of produced water were particularly close to the lake, the cove affected is narrow and restricted, and the preliminary data derived from the USGS studies clearly illustrate that produced water is entering the aquatic system.

\section{Phase 1 Research Activities}

As part of the OSPER project, the USGS drilled 29 shallow (one to three meters deep) groundwater wells at the production site that allow for the characterization of shallow groundwater and assessment of produced water intrusion (Figure 2, but also see http://ok.water.usgs.gov/skiatook/). Six 33-m transects were established at the production and reference site. Three transects running west to east (off of wells BE07 and BE62, and approximately 8 meters north of the BE07 transect) and one running north to south (of groundwater well BE62) were established at the production site, with two transects running north to south at the reference site.

\section{Task 1.0 - Definitive characterization of produced water infiltration into the receiving system.}

Produced water was collected from onsite storage tanks in one-liter amber bottles with Teflon coated lids, filled from the bottom with a hose to reduce volatile chemical loss and minimize headspace, and held at $4^{\circ} \mathrm{C}$. Bimonthly monitoring of produced water (September 2005 to May 2007) from onsite storage tanks included basic water quality measures (ammonia, $\mathrm{pH}$, conductivity, alkalinity, and hardness). Hydrocarbons were extracted and analyzed (US EPA method 8015B, Accurate Labs Inc., Stillwater, OK) for BTEX (benzene, toluene, ethyl-benzene, and xylene), gasoline range organics (GRO) and diesel range organics (DRO). These categories were meant 
to quantify the amount and general molecule size range of the hydrocarbons that may be present in water samples. Finally, produced water samples were sent to the Oklahoma Cooperative Extension Service's Soil, Water, and Forage Analytical Laboratory at Oklahoma State University. This laboratory measured concentrations of sodium, calcium, magnesium, potassium, nitrate, chloride, sulfate, boron, and bicarbonate.

To test for produced water intrusion, one well volume (the volume of water contained within and extractable from a well) of water from all accessible groundwater wells was collected using a hand pump concurrently with produced water sampling and filtered using Whatman GF/A glass fiber filters to remove sediment. Basic physicochemical properties ( $\mathrm{pH}$ - Fisher Scientific (Pittsburgh, PA) Accumet AP62 portable pH meter, conductivity - Fisher Scientific Accumet AP65 portable conductivity meter, alkalinity - US EPA method 310.1, and hardness - US EPA method D1126-96) were measured on groundwater samples. During February and May of 2007, well water samples were sent to the Oklahoma Cooperative Extension Service's Soil, Water, and Forage Analytical Laboratory at Oklahoma State University to characterize the same ion concentrations as those measured for produced water. Further analytical characterization of groundwater samples was not feasible because maximum sample volume typically did not exceed $500 \mathrm{~mL}$, and was commonly $300 \mathrm{~mL}$ or less.

Three aquatic sediment cores $(30 \mathrm{~cm}$ long by $1 \mathrm{~cm}$ wide - Wildco (Buffalo, NY) hand corer with polyethylene sample sleeves) were taken along each transect at the study sites during field sampling to a depth of $30 \mathrm{~cm}$. Though greater numbers of core samples were originally proposed, the rocky substrate of the lake bottom required multiple attempts to drive each core sample into the substrate. The sampling accomplished represents one field day each season devoted to diving and attempting to collect core samples. Pore water was extracted from $5-\mathrm{cm}$ sections of the cores in 50 $\mathrm{ml}$ tubes via centrifugation at $4100 \mathrm{rpm}$ for 30 minutes at $23^{\circ} \mathrm{C}$. Extracted pore water was then analyzed for brine contamination using specific conductance as a surrogate. Based on guidance from the analytical laboratory, samples were sent to the Oklahoma Cooperative Extension Service's Soil, Water, and Forage Analytical Laboratory at Oklahoma State University for major ions analysis, as was done with the produced water samples. The analytical laboratory measured as many ions as feasible (depending on sample volume and ion content) starting with chloride, then measuring cations, and then anions. Ion concentrations were used to predict potential pore water toxicity to the standardized bioassay organism $D$. magna using an lon Toxicity model (Tietge et al. 1997). The pore waters collected were of insufficient volume to allow quantification of bicarbonate concentrations and these concentrations were assumed to be either zero or the maximum value detected $(938 \mathrm{mg} / \mathrm{L})$ during toxicity modeling. When the concentrations were assumed to be zero if bicarbonate concentrations were greater than this value then predicted toxicity would increase, whereas if bicarbonate concentrations were lower then predicted toxicity would decrease. This resulted in both conservative estimates (worst-case scenario) and best-case scenario estimates of potential toxicity with which comparisons could be made.

During the Fall of 2005 water along the sediment-water interface in the lake was sampled at each oil production site transect to test for produced water flow into Skiatook Lake. Water samples were collected in $20 \mathrm{ml}$ syringes every $0.5 \mathrm{~m}$ along each transect 
and tested for conductivity. These results were then compared with conductivity observed in the lake during the course of this study.

\section{Phase 2 Research Activities}

Task 1.0 - Routine laboratory toxicity testing of produced water and groundwater samples

Static renewal acute (48hr) and chronic (7d) testing of the produced water samples collected for water analyses were run within 48 hours of collection and in addition to chemical analyses during bimonthly sampling events. All water samples were held on ice in the field and at $4^{\circ} \mathrm{C}$ once in storage at the laboratory. Acute tests utilized the test organisms D. pulex and D. magna (US EPA 2002a), while chronic tests used Ceriodaphnia dubia and the fathead minnow Pimephales promelas (US EPA 2002b).

\section{Task 2.0 - Toxicity identification evaluation of produced water samples}

Toxicity Identification Evaluation (TIE) is a US EPA (1992) standardized series of water manipulations and toxicity tests meant to identify toxic constituents of a complex mixture or effluent. Manipulations performed and tested on D. pulex included unadjusted effluent; chelation with EDTA (to test for metal toxicity); oxidation with sodium thiosulfate; adjustment to $\mathrm{pH} 6,7$, and 8 (to test for $\mathrm{pH}$ - dependent toxicants); and aeration, filtration (through a glass fiber filter to remove particulates), and $\mathrm{C} 18$ solid phase extraction (SPE, removes nonpolar organic chemicals) at initial $\mathrm{pH}, \mathrm{pH} 3$ and $\mathrm{pH}$ 11. Evaluations were conducted in February 2006, March 2007, and September 2007.

Mount et al. (1992, 1997) derived an Ion Toxicity Model that uses empirically derived statistical models to predict major or essential ion $\left(\mathrm{Na}, \mathrm{K}, \mathrm{Ca}, \mathrm{Mg}, \mathrm{Cl}, \mathrm{SO}_{4}\right.$, and $\mathrm{HCO}_{3}$ ) toxicity to three standardized bioassay organisms (Pimephales promelas, Ceriodaphnia dubia, and Daphnia magna) in response to concerns about increased discharges of oil-field produced waters. This model uses major ion concentrations as predictors of organism survival in a multiple logistic regression. Major ion salts were a significant component of produced water toxicity and this model has previously been used to assess toxic constituents of produced waters (Tietge et al. 1997). Evaluations were supplemented with comparisons of produced water toxicity as determined during routine laboratory toxicity testing with $D$. magna, $C$. dubia, and fathead minnows with values predicted using an Ion Toxicity Model (Gulley et al. 1992). This model accounts for toxicity due to major ion salts, in each round of toxicity monitoring without extensive toxicity identification evaluation (TIE) procedures. Major ion salts are an expected component of produced water toxicity and this model definitively demonstrates the contribution of these salts to overall mixture toxicity.

Further experiments were conducted to test for the effects of hydrocarbons on test organisms. Full toxicity tests with $D$. magna were conducted on produced water samples in June 2007. Tests were performed on raw produced water, produced water with hydrocarbons removed (using $\mathrm{C} 18$ solid phase extraction), and in laboratory water spiked with the material retained on the C18 SPE columns (following US EPA 1991). These data, coupled with predictions of toxicity based on major ion salt concentrations were then used calculate the effect hydrocarbons had on observed produced water toxicity. 


\section{Phase 3 Research Activities}

Water quality monitoring and static renewal acute toxicity testing (48hr) with Daphnia pulex (US EPA 2002a) on selected groundwater wells coincided with bimonthly monitoring of produced water quality. Wells were selected to capture gradients in groundwater quality from potential produced water sources (evaporation pond and injection well) to the lakeshore. D. pulex was chosen as the test organism because Oklahoma Department of Environmental Quality regulations (252:690-3-29) specify this organism for acute whole effluent toxicity (WET) testing and the volume of sampled water from the groundwater wells was insufficient to conduct a battery of tests on multiple test species as was done for produced water samples.

In February and May 2007 groundwater samples were sent to the Oklahoma Cooperative Extension Service's Soil, Water, and Forage Analytical Laboratory to generate major ion profiles for each sampling well. These ion profiles were then incorporated into an lon Toxicity Model and predictions from this model were used to create a Geographic Information System (GIS) surface to model predicted groundwater toxicity across the entire study site. Briefly, ArcMap 9.1 used the predicted groundwater toxicity of each well to predict groundwater toxicity for groundwater not directly sampled and based these predictions on the values for the nearest groundwater wells and the distance to those wells. The specific interpolation method used here is called ordinary kriging. The resulting surfaces show predicted toxicity of groundwater across the site.

\section{Task 1.0 - Assessment of benthic community condition}

Multi-plate samplers were employed to assess benthic community response to field conditions. Sediment cores were originally proposed and attempted, but the rocky lake substrate prevented reliable and replicated use. Multi-plate samplers may better sample local diversity, particularly that associated with hard substrates, and they also may reduce sample variability, though artificial substrates select for organisms that colonize them (Rosenberg and Resh 1982). Four multi-plate samplers were deployed at one location along each transect plus four more in the submerged brine pit for six weeks, twice a year, during historic high and low water levels (Cover and Harrel 1978), though sampling depth along each transect were within 1.5 meters of each other. Macroinvertebrate samples were sorted and identified to the lowest practical taxon (Merrit and Cummins 1996; Epler 2001; Smith 2001). Macroinvertebrate community composition and Shannon-Wiener Diversity were compared between sites.

\section{Task 2.0 - In-situ bioassays}

Tests with the midge Chironomus dilutus, the amphipod Hyallela azteca (US EPA 2000), and the Asian Clam Corbicula fluminea coincided with field sampling. Midges and amphipods were collected from existing laboratory cultures (US EPA 2000), while clams were collected from a local infested stream (tail waters of Canton Lake, Blain County, Oklahoma). Midge and amphipod experiments utilized cylindrical, clear plastic, vented exposure chambers (12.5 cm long by $7 \mathrm{~cm}$ wide, following Burton et al. 2005), whereas clams were exposed in orange mesh bags. Both tests utilized ten organisms per experimental unit (an exposure chamber or mesh bag) and occurred at three locations: reference site, submerged brine pit, and along transect two, which is in line 
with the major salt scar. There were also three position treatments of amphipod enclosures with four enclosures per treatment at each location: containing surficial sediment, laying on the sediment, and suspended in the water column. Midge and amphipod enclosures were harvested after a ten-day incubation when survival and mean growth per chamber endpoints were measured. Asian Clams were individually marked ( $8 \times 4 \mathrm{~mm}$ type FPN shellfish tags, Hallprint Pty Ltd., Victor Harbor, South Australia) such that each clam from each experimental unit was measured before and after incubation so that there were ten replicate organisms per experimental unit. Marked clams of approximately two centimeters in length measured using a digital caliper (to the nearest $0.005 \mathrm{~mm}$ ) along the longest shell dimension (anterior to posterior) were placed into orange mesh bags (experimental unit) and then secured on the lake benthos with marking flags. At least two mesh bag experimental units were placed at each location and incubated for thirty days after which growth and survival endpoints were measured (Soucek et al. 2001). These experiments coincided with benthic macroinvertebrate community sampling in May (high water) and September (low water) each year. Amphipod experiments were conducted on August 14, 2007, September 9, 2007, and October 6, 2007. Asian clam experiments were conducted on August 17, 2005, May 16, 2006, October 5, 2006, and September 8, 2007.

\section{Task 3.0 - Comparison of laboratory and field data}

Laboratory sediment toxicity tests with amphipods were conducted in addition to in situ bioassays (US EPA 2000). Sediment was collected from the top $5 \mathrm{~cm}$ of the lake bottom using the plastic sample containers used for storage and placed on ice for transport back to the laboratory where they were held at $4^{\circ} \mathrm{C}$ until testing. Samples were from the same locations as the field experiments and allowed powerful comparisons between laboratory and field experiments. Sediment tests occurred within eight weeks of sample collection (US EPA 2000). The numerous methods employed here also allowed comparison of the various assessment techniques between field and laboratory conditions.

Statistical Analyses

Most statistical analyses were conducted using SAS 9.1 (PROC GLIMMIX, The SAS Institute, Cary, NC). Asian clam data was analyzed using analysis of covariance with initial organism size as the covariate. Macroinvertebrate data was natural log transformed and analyzed using a multivariate analysis of variance to explore differences in sample location and sample season. Toxicological endpoints such as $\mathrm{LC}_{50}$ 's and confidence limits were performed using the Comprehensive Environmental Toxicity Information System (CETIS) version 1.1.2 (Tidepool Scientific Software, McKinleyville, CA).

\section{Results and Discussion \\ Phase 1}

Task 1.0-Definitive characterization of produced water infiltration into the receiving system.

Produced water is a complex mixture containing many potential toxicants. These constituents include major ions ( $\mathrm{Na}, \mathrm{Ca}, \mathrm{K}, \mathrm{Mg}, \mathrm{Cl}, \mathrm{SO}_{4}$ ), ammonia, hydrogen sulfide, petroleum hydrocarbons, BTEX (benzene, toluene, ethyl-benzene, and xylenes), 
phenols, naphthalenes, zinc, and other heavy metals (Fucik 1992; Schiff et al. 1992; Stromgren et al. 1995; Smith et al. 1998; Kharaka et al. 2005). These constituents vary between and within different geologic basins depending on geology and hydrology (Daly and Mesing 1995; Collins 1985).

In the present study, produced water major ion profiles and basic water quality parameters were collected from December 2005 to September 2007 (Figure 3). Measured parameters ranged as follows: $\mathrm{pH}$ (3.7 to 6.9), conductivity (84,800 to $186,000 \mu \mathrm{S} / \mathrm{cm}$ ), alkalinity $\left(0\right.$ to $\left.68 \mathrm{mg} / \mathrm{l} \mathrm{CaCO}_{3}\right)$, hardness $(8,615$ to $186,000 \mathrm{mg} / \mathrm{l}$ $\left.\mathrm{CaCO}_{3}\right)$, sodium $(21,399$ to $48,677 \mathrm{mg} / \mathrm{l})$, calcium $(2,351$ to $8,642 \mathrm{mg} / \mathrm{l})$, magnesium (668 to $1,689 \mathrm{mg} / \mathrm{l})$, potassium (75 to $535 \mathrm{mg} / \mathrm{l})$, nitrate (0 to $3 \mathrm{mg} / \mathrm{l})$, chloride $(36,395$ to $93,989 \mathrm{mg} / \mathrm{l}$ ), sulfate (83 to $353 \mathrm{mg} / \mathrm{l})$, bicarbonate (0 to $83 \mathrm{mg} / \mathrm{l})$, ammonia (27.7 to 63.6 $\mathrm{mg} / \mathrm{l}$ ), and boron ( 0.77 to $4.26 \mathrm{mg} / \mathrm{l})$. Hydrocarbon concentrations were measured starting in March 2006 through September 2007 and ranged from 0.42 to $6.53 \mathrm{mg} / \mathrm{l}$ for BTEX, 1.0 to $10.0 \mathrm{mg} / \mathrm{l} \mathrm{GRO}$, and 2.6 to $9.6 \mathrm{mg} / \mathrm{LRO}$ (Figure 4). Sodium chloride salts dominated the major ions and hydrocarbons were evenly split between benzene, GRO, and DRO.

Some of the field component of the project was negatively affected by extreme weather conditions during the 2006 and 2007 field seasons. During the summer of 2006, much of the state of Oklahoma was in the midst of a severe drought which lead to a significant drop in lake levels such that most of the underwater sampling sites were exposed (Figure 5, $6 \& 7$ ). Then in 2007, heavy rain through the spring and early summer caused lake levels to rise so that the majority of groundwater wells became inaccessible after the May sampling period (see hydrograph on Figure 5) and the underwater transects could not be accessed due to extremely poor visibility and extensive amount of debris in the water. These weather conditions precluded sampling for chemical analyses and initiation of any in situ studies.

In addition, beginning in December 2006 and through March 2007, oil production was shut down at the site and eventually resulted in a change in site operations. These changes initially resulted in diminishing quantities of produced water that could be collected from the site and changes in operations after March changed how produced water was managed at the site. This change meant that rather than being available from the on-site tank battery, produced water could only be collected from an injection well on the northernmost side of the site (INJWELL10A in Figure 2) when that well was in use, resulting in inconsistencies in produced water availability. Produced water quality also changed after this site management change, evidenced by increased hydrocarbon concentrations and greater variability in major ion concentrations (both the minimum and maximum measured concentrations for all ions were measured after this period). Before this change the southern injection well (INJWELL14) was the predominantly-used well, and produced water could be easily collected from the tank battery located along the evaporation pond.

Groundwater wells were sampled from September 2005 through May 2007. Flooding during the spring of 2007 rendered the majority of groundwater wells inaccessible to sampling after the May sampling period (the tops of the wells were below the lake surface). Water quality parameters were measured during each sampling period (Tables 1, 2, 3, and 4) and ranged from 3.90 to 8.24 for $\mathrm{pH}$, from 1,374 to $38,100 \mu \mathrm{S} / \mathrm{cm}$ for conductivity, from 0 to $1,178 \mathrm{mg} / \mathrm{l} \mathrm{CaCO}_{3}$ for alkalinity, and from 
169 to $20,000 \mathrm{mg} / \mathrm{l} \mathrm{CaCO}_{3}$ for hardness. In general, $\mathrm{pH}$ and alkalinity were lowest while conductivity and hardness were greatest in wells located near the brine injection well.

During February 2007, major ion profiles were measured on each sample well. These data were then analyzed using a principle components analysis (PCA) to explore possible trends in groundwater ion composition. Principle components analysis creates a linear combination of all measured variables for each sample. These linear combinations are then used to create new axes on which the samples can be plotted. A symmetric biplot (which scales variables and samples equally to produce an even appearing graphic) of these profiles for each sample well was created using the PCA (Figure 8). Wells were plotted along the first two PCA axes and these axes explained $89.5 \%$ of the variation in well ion profiles. The first (horizontal) PCA axis potentially represents biogeochemical processing of intruded produced water (such as bicarbonate buffering, chloride exchange for sulfate via hematite, and bacterial removal of nitrate) or dilution from other groundwater sources. The second (vertical) PCA axis represents the dilution gradient from raw produced water to lake water.

Pore water samples collected from replicate sediment cores along each field transect yielded different results at the reference site compared with the oil production site. Reference core samples exhibited more constant $\mathrm{pH}$, conductivity (Table 5), and ion concentrations with depth (Table 6). Conductivity and ion concentrations tended to increase with sample depth for the oil production site samples. $\mathrm{pH}$ dropped dramatically with depth on the first transect whereas $\mathrm{pH}$ was relatively constant on transect three and increased on transect two and in the submerged brine pit. Major ion profiles of each sediment core section tended to reflect conductivity readings with increased conductivity corresponding to greater concentration of all ions. Potential toxicity of these pore waters to the test organism Daphnia magna was predicted using an ion toxicity model and indicated that some pore waters may cause mortality if organisms were exposed to these waters (Table 7). Potential toxicity is reported in toxicity units (TU's) which is the predicted 48-hr $\mathrm{LC}_{50}$ to $D$. magna divided by the original concentration. Toxicity units greater than one indicate samples where an $\mathrm{LC}_{50}$ would be observed if a bioassay had been possible.

Overall, raw produced water from the oil production site was characterized primarily by decreased $\mathrm{pH}$, excesses in major ion salts (sodium, calcium, and chloride), and other contaminants (ammonia, boron, and hydrocarbons). Tietge et al. (1997) examined produced waters from around the United States and found sodium chloride and sodium bicarbonate salts as the primary toxicants, and additional toxicity resulted from nonpolar organic compounds or other unidentifiable toxicants.

Oil production operations have been shown to contaminate nearby groundwater with excess metals. For example, non-essential metals, including arsenic, cadmium and copper, were reported in groundwater samples adjacent to a petrochemical complex in Saudi Arabia (Sadiq and Alam 1997). The most commonly used disposal method, and the method currently in use at the site used for the present study, is water flooding where produced water is reinjected back into the petroleum seam to improve production. This process is associated with fewer environmental effects compared with other options, though groundwater contamination is possible. For example, a freshwater aquifer in Turkey was contaminated from a brine reinjection operation up to $18.7 \mathrm{~km}$ away from the injection source (Okandan et al. 2001). Hudak and Blanchard 
(1997) suggested that oil field brine contamination from oil and gas wells in northern Texas increased groundwater concentrations of chloride and bromide.

Brine contamination of the near-surface aquifer at both OSPER sites has been reported previously (Kharaka et al. 2002), and groundwater modeling at the OSPER-B site (oil production site) demonstrated that contaminating brine travels between two and four years in the near-surface aquifer before entering Skiatook Lake (Herkelrath and Kharaka 2002). Sediment cores taken throughout the oil production site, especially those south of transect one, exhibited conductivity and ion concentrations consistent with produced water contamination. Contamination increased with depth, suggesting dilution or leaching of contaminated pore water by lake water. All groundwater wells exhibited $\mathrm{pH}$, conductivity, alkalinity and hardness at levels intermediate between produced water and lake water. Groundwater samples tended to have more bicarbonate and sulfate compared to produced water samples, although wells located near the injection well were more similar to raw produced water samples, supporting the previous findings of brine contamination at the site (Kharaka et al. 2002).

Water samples taken from the sediment-water interface during the fall of 2005 indicated no conductivity abnormalities that were beyond the normal variation in conductivity observed in Skiatook Lake during the study (Figure 9). As such, this conductivity survey was unable to locate evidence of contaminated groundwater flow into Skiatook Lake. The use of mini-piezometers to indicate upwelling of groundwater in the sub-littoral zone of the lake was also unsuccessful due to the rocky nature of the lake substrate near the shoreline at the oil production site.

These results indicate that produced water appears to be a significant contaminant of groundwater at the oil production site, particularly near the injection well, and also may occur in pore water of lake sediments. Toxicity modeling indicates that pore waters would probably not affect biota at sediment depths less than $10 \mathrm{~cm}$ at the most contaminated sampling locations. Based on these results, the potential plume of contaminated groundwater underneath Skiatook Lake may extend beyond the study area, but likely does not significantly infiltrate surficial sediments or the water column.

\section{Phase 2}

Task 1.0 - Routine laboratory toxicity testing of produced water and groundwater samples

Acute and chronic toxicity tests with the four standard test organisms were conducted from January 2006 through March 2007 (Figure 10). Acute 48-hr LC 50 's ranged from $0.94 \%$ to $4.13 \%$ for D. pulex, $2.68 \%$ to $5.36 \%$ for D. magna, $2.06 \%$ to $2.74 \%$ for C. dubia, and $7.44 \%$ to $11.19 \%$ for fathead minnows. Acute 48 -hr endpoints for $C$. dubia and fathead minnows were generated from daily monitoring of the chronic 7 -d tests and these organisms were fed during the acute period, unlike $D$. pulex and $D$. magna tests. Chronic $7-d$ LC $_{50}$ 's for C. dubia ranged from $1.78 \%$ to $2.74 \%$ and from $2.96 \%$ to $5.80 \%$ for fathead minnows. Chronic 7-d EC50's for C. dubia reproduction ranged from $1.00 \%$ to $1.66 \%$ and from $2.20 \%$ to $6.51 \%$ for fathead minnow growth.

In previous studies examining the effects of produced water on aquatic test species, the freshwater cladoceran, Ceriodaphnia dubia, was found to be more sensitive to produced water than the fathead minnow, Pimephales promelas (Boelter et al. 1992; Fucik 1992). Boelter et al. (1992) tested water from streams receiving 
produced water in Wyoming and found that $C$. dubia was sensitive to major inorganic ions present in the discharge, while fathead minnows did not exhibit a response. Laboratory toxicity tests were shown to be valid measures of stream quality when compared with benthic macroinvertebrate samples in Alabama streams receiving produced water (Mount et al. 1992). Despite these findings, laboratory toxicity testing may overestimate produced water effects because dilutions used for such tests may represent effluent concentrations only present at the immediate discharge point (Douglas and Veil 1996). Evaluating the environmental effects of produced water discharges should incorporate multiple lines of investigation including chemical quality of the effluent and receiving system, toxicity testing, biomonitoring, and specific continuous monitoring of conductivity and chloride as indicators of brine water (O'Neil et al. 1992b).

Bimonthly monitoring of groundwater acute ( $48 \mathrm{hr}$ ) toxicity to $D$. pulex occurred from September 2005 through May 2007. Toxicity was greatest near a brine injection well and lowest in a well adjacent to the evaporation pond in a vegetated area. Toxicity (expressed as percent of the groundwater sample) at the first transect (northernmost, see Figure 2), running along a salt scar from the injection well to the lake, ranged from $2.12 \%$ to $31.5 \%$ in BE 53 and $13.45 \%$ to $36.75 \%$ in BE18 (Figure 11 ). Toxicity along the transect going from the evaporation pond to the lake along a salt scar ranged from $5.76 \%$ to $35.35 \%$ in BE11, $12.04 \%$ to $35.35 \%$ in BE08, and $2.99 \%$ to $30.82 \%$ in BE07 (Figure 12). Observed toxicity in the vegetated transect running from the evaporation pond to the lake ranged from $48.07 \%$ to no observed effects in BE59, $11.71 \%$ to $56.81 \%$ in BE61, and $9.25 \%$ to $65.56 \%$ in BE16 (Figure 13).

Major ion profiles for groundwater wells sampled in the spring of 2007 were used to generate surfaces in GIS. Briefly, ArcMap 9.1 used the predicted groundwater toxicity of each well to predict groundwater toxicity for groundwater not directly sampled and based these predictions on the values for the nearest groundwater wells and the distance to those wells. The specific interpolation method used here is called ordinary kriging. The resulting surfaces show predicted toxicity of groundwater across the site (Figure 14). The graphical representations of predicted toxicity support the previous finding that toxicity is greatest near the injection well on the northwestern side of the site. Acute 48-hr toxicity tests on selected groundwater wells using D. magna were compared with predictions from an lon toxicity model to validate the toxicity predictions used in the GIS model (Figure 15). The predictions fell relatively close for all wells tested, except BE53, which is the closest groundwater test well to the brine injection well. In samples from this site, the observed toxicity to $D$. magna was greater than model predictions. In addition to predicted toxicity, Figure 14 also includes an image generated by the United States Geological Survey (USGS, Robert A. Zielinski, personal communication) using a remote sensing device (GEM2) that detects surficial electrical conductance, which is a surrogate for salt contamination. These results suggest that for all groundwater wells, except for those closest to produced water sources, toxicity results from elevated major ions. Further, these data support the use of the GIS model surfaces for other produced water contaminated sites, with some limitations. This modeling assumes that all toxicity is derived from major ion excesses. Toxicity testing with the test organism modeled, as was done here, is needed to detect the presence of other toxic groundwater constituents and validate predictions. 


\section{Task 2.0 - Toxicity identification evaluation of produced water samples}

Toxicity identification evaluation (TIE) of produced water resulted in reduced toxicity due to chelation by ethylenediaminetetraacetic acid (EDTA, indicating metal toxicity), oxidant reduction with sodium thiosulfate (indicating chloride or other oxidant toxicity) filtration at $\mathrm{pH} 11$ (potential hydrocarbon toxicity), and aeration at $\mathrm{pH} 10$ (volatile chemicals) when compared to the baseline toxicity of unmodified produced water (Table 8). The February 2006 TIE on Table 8 was run twice so comparisons could be made on the logistic regression model curves used to generate $48-\mathrm{hr}^{2} \mathrm{LC}_{50}$ 's, similar to an ANOVA, whereas the other TIE's were only run once and the $95 \%$ confidence interval of the baseline (unmodified) treatment was used to find toxicity reductions. These results suggest that on the February 2006 and September 2007 runs, produced water toxicity came from metals (including major ion salts), possibly chloride, hydrocarbons removed from solution by high $\mathrm{pH}$, and volatile chemicals.

Comparisons between observed $48 \mathrm{~h} \mathrm{LC}_{50}$ 's and those predicted from major ion concentrations differed depending on the test organism (Figure 16). Fathead minnow lethal concentrations were most similar to predicted values, indicating that major ions were the dominant, if not only source of toxicity to these organisms. Observed 48-hr $\mathrm{LC}_{50}$ 's for $C$. dubia and $\mathrm{D}$. magna indicated greater toxicity than predicted values and were likely affected by toxicants other than major ions. The TIE's run using $D$. pulex support the finding of toxicity greater than can be predicted from major ions alone and that toxicants other than major ions are responsible for mixture toxicity. When Tietge et al. (1997) compared toxicity test results of six produced waters from across the United States, two samples were found to exhibit toxicity beyond what was predicted by ion toxicity modeling.

Removal of hydrocarbons from produced water using $\mathrm{C} 18$ solid phase extraction did not significantly reduce $48-\mathrm{hr}$ mixture toxicity to $D$. magna $(P=0.8181)$, however the retained non-polar organics did elicit a toxic response from test organisms when eluted into a clean solution. Overall, produced water toxicity contained 22.91 toxicity units (TU), of which 7.77 TU's can be explained by major ion toxicity and 8.48 resulted from hydrocarbons and other non-polar organics. The remaining 6.66 toxicity units fell well within the $95 \%$ confidence interval (13 to 34 toxicity units) of the original mixture $48-\mathrm{hr}$ $\mathrm{LC}_{50}$. Despite the demonstration of toxicity derived from hydrocarbons, plots of mixture TU's, with TU's accounted for by ion toxicity removed (total TU's minus major ion TU's, from the lon toxicity model), versus total petroleum hydrocarbons (TPH) result in no demonstrable relationship for any of the test organisms (Figure 17). Produced water caused test organism mortality at concentrations below $10 \%$, and for some organisms (D. pulex) below $1 \%$. Fathead minnows were least sensitive to produced water with 48hr LC 50 's averaging $8.42 \%$, followed by D. magna at $3.69 \%$, then $C$. dubia at $3.12 \%$, and with $D$. pulex at $2.36 \%$ as the most sensitive. These results are similar to those found for produced water from around the United States by Tietge et al. (1997), but are more toxic than the majority of samples examined by Fucik (1992). Fucik (1992) suggested that hydrocarbons and semi-volatile compounds were responsible for test organism mortality, in addition to dissolved solids, in produced waters where cladoceran toxicity was greater than that found for fathead minnows. While produced water toxicity did vary over time, no discernable pattern emerged from the data. 
Toxicity identification evaluations of produced waters from multiple locations in the United States have consistently identified elevated salinity as a source of toxicity (Tietge et al. 1997). Other sources of toxicity include major ion imbalances, hydrocarbons, ammonia, and hydrogen sulfide (Boelter et al. 1992; Sauer et al. 1997; Elias-Samlalsingh et al. 2004). Gulley et al (1992) and Mount et al. (1992) found that toxicity resulting from major ion salinity could be accurately predicted and accounted for using statistically-derived ion toxicity models. Due to concerns regarding increasing discharges of oil field produced waters, statistical models of major ion toxicity to Pimephales promelas, Daphnia magna, and Ceriodaphnia dubia have been developed to predict toxicity resulting from exposure to saline waters (Gulley et al. 1992). Major ion concentrations and toxicity tests checked against predictions from the ion toxicity model could accurately determine whether further phase I TIE was necessary by accounting for all toxic units observed. Produced-water contaminated groundwater from sites along Skiatook Lake have shown elevated concentrations of major ions, strontium, iron, dissolved organic carbon, and acetate (Kharaka et al. 2005). Ion toxicity modeling incorporated into TIE procedures determined which produced water mixture constituents contribute to overall toxicity (Tietge et al. 1997).

Previous produced water investigations using the ion toxicity model coupled with TIE procedures (Tietge et al. 1997), the demonstration of toxic levels of hydrocarbons present in site produced water, and TIE's performed in this study, indicate hydrocarbons are also a potential component of overall toxicity. Salts have already been shown as an important source of toxicity in groundwater and lake sediment pore waters. Hydrocarbons may degrade quickly or adsorb to organic matter present in the groundwater matrix and result in little measured effect. Other potential toxicants, such as ammonia, may be masked by other mixture components present at more toxic concentrations. For example, produced water samples from this study contained at least eight toxic units of major ion salt toxicity, whereas total ammonia at $\mathrm{pH} 6.5$ exhibits a $96 \mathrm{~h} \mathrm{LC} \mathrm{L}_{50}$ to fathead minnows at $254 \mathrm{mg} / \mathrm{l}$ (Thurston et al. 1981), over four times that found in site produced waters.

\section{Phase 3}

\section{Task 1.0 - Assessment of benthic community condition}

Several methods can be used to assess benthic macroinvertebrate community structure including in-vitro and in-situ sediment toxicity assessments, and macroinvertebrate community sampling. In situ studies incorporate experimental controls into field conditions to better represent site conditions while retaining some of the advantages of laboratory experiments. Unfortunately, in situ studies do not always mirror field or laboratory study results, confounding applicability. The most environmentally-relevant method to measure disturbance effects on resident communities is to compare the community structure of potentially impacted communities with unaffected communities, though this approach is time consuming and subject to environmental variability that may overwhelm treatment effects.

Sediment-dwelling or benthic macroinvertebrates are ideal study organisms because they are ubiquitous, diverse, relatively immobile (compared with freshwater vertebrates), and have lifecycles that, depending on species, can last from one month to multiple years (Rosenberg and Resh 1993). Currently, 49 of 50 US states employ 
benthic macroinvertebrate surveys as a part of routine biomonitoring activities (Carter et al. 2006). Benthic macroinvertebrate monitoring has been used to assess the impact of short-term saline inputs on stream communities (Marshall and Bailey 2004) and to determine the effects of metals (cadmium, copper, lead, and zinc) along salinity gradients (Peeters et al. 2000).

In the present study, benthic macroinvertebrates exhibited few differences between sample sites. Of the nineteen organisms found in more than $10 \%$ of samples, only the aquatic earthworm, Lumbriculus spp. (tolerance value of eight, higher numbers correspond to greater tolerance of stressful environmental conditions, Carter et al. 2006), was found in greater abundance at the reference site, whereas the mayflies Stenonema femoratum (tolerance value of four) and Paracloedes spp. (tolerance value of four) were both found in greater abundances at the oil production site (Figure 18). Shannon-Wiener diversity did not differ between locations at the oil production and reference sites, though richness and diversity tended to be greater at the oil production site compared with the reference (Table 9).

Previous freshwater studies of the instream biological effects of produced water discharges summarized by O'Neil (1992a), found few or no significant effects on resident biota. However, some chronic brine discharges from oil operations have been found to significantly change benthic communities. For example, Olive et al. (1992) reported a lower percent Trichoptera (Caddisflies) and decreased invertebrate density in a stream impacted by brine discharges. Biologic Integrity of invertebrate communities in two Ohio brine-receiving streams were unchanged compared to reference sites, though greater percentages of salt-tolerant diatoms were present and chloride concentrations did not exceed $74 \mathrm{mg} / \mathrm{L}$ (Olive et al. 1992). In a drainage system chronically exposed to high levels of salts from oilfield operations, Short et al. (1991) found that while fishes and Dipteran larvae were tolerant of salinities as high as $10 \%$, mayfly larvae (Ephemeroptera) were absent when salinities exceeded 2 \%. O'Neil et al. (1992a,b) observed that more benthic macroinvertebrate taxa were found at a site in the Warrior Basin, Alabama where there was less produced water-associated sulfate. Most previous studies of the environmental effects of produced water on benthic communities have been limited to lotic systems, however macroinvertebrates are still useful tools in biomonitoring for lentic systems. The difference between lotic and lentic systems necessitates different sampling devices and implies a change in overall community composition, but the ecological theory behind the application remains unchanged.

\section{Task 2.0 - Sediment bioassays and In-situ studies}

Toxicity testing of sediments, like water column tests, provides information on the potential biotic effects from sediment contaminants. Contaminant concentrations in sediments may exceed water column concentrations by several orders of magnitude due to preferential sorption and partitioning of contaminants to the sediment matrix (Burton 1991). This concentration difference can result in adverse effects to sediment dwelling organisms while water column-based tests indicate no observed effects (Chapman 1989). Sorption to the sediment depends on many factors including the individual chemical properties of the contaminant and sediment properties such as $\mathrm{pH}$, redox, organic carbon, grain size, and inorganic particles (DiToro et al. 1991). Chemical analyses of sediment contaminants can only address potential bioavailability, whereas 
benthic community analyses can be confounded by numerous factors unrelated to sediment contamination. Sediment toxicity tests therefore serve as an intermediate method between chemical analyses and community sampling by using biota as indicators of toxicity and allowing direct links to be made between chemical composition, bioavailability, and benthic biotic effects (US EPA 2000).

As with other standardized laboratory test procedures, sediment toxicity tests are usually conducted under controlled conditions which may undermine the "real world" applicability of toxicity test results. In situ toxicity testing provides an intermediate level of experimental control between laboratory experiments and field sampling of resident communities, while incorporating environmental variability, thus increasing applicability (Burton et al. 2005). Due to the potential for in situ studies to link and validate laboratory experiments with field surveys, in situ studies should consistently mirror results of other assessment methods.

The midge, Chironomus dilutus (formerly C. tentans; Shobanov et al. 1999), and the amphipod, Hyallela azteca, can be used for both laboratory sediment toxicity tests and in situ assays. Simultaneous use of a test organism for laboratory and field experiments allows greater experimental control and reduces errors made when extrapolating the results of traditional toxicity tests to the environment (Burton et al. 2005). Both of these organisms have been successfully used to evaluate sediment toxicity, with those evaluations confirmed using natural benthic populations (US EPA 2000). For example, experiments comparing the response of chronic $\mathrm{H}$. azteca bioassays with field-collected benthic community data demonstrated similar responses to increasing concentrations of polycyclic aromatic hydrocarbons (Ingersoll et al. 2005). Tucker and Burton (1999) found that comparisons of laboratory and in situ exposures of both test organisms to agricultural and urban runoff, especially when combined with benthic community assessment, provided a more comprehensive and environmentally relevant assessment than either method alone.

Initial experiments with $C$. dilutus in laboratory sediment toxicity tests resulted in no significant differences in growth, although there does appear to be reduced survival at both oil production site locations compared to the reference site (Figure 19). Sediment experiments with the amphipod, Hyallela azteca, revealed no significant differences in mortality between any treatments in both lab and in situ experiments. Few differences in amphipod growth were found during laboratory experiments (Figure 20). In the in situ study with $H$. azteca, a significant triple interaction between sediment treatment, location, and experiment run was apparent which makes direct site comparisons difficult. Still, amphipods at both locations at the oil production site exhibited lower growth than those placed at the reference site, regardless of experiment run (Figure 21).

The invasive Asian clam, Corbicula fluminea, has been effectively employed to monitor both sediment and water quality in previously infested environments and found to accurately reflect resident benthic community responses (Doherty 1990; Cataldo et al. 2001; Soucek et al. 2001). Clam tissues may or may not accumulate contaminants, such as metals, and accumulation rates can vary greatly between contaminants and field sites, but growth consistently reflects field conditions (Cataldo et al. 2001). Asian clams have successfully been used alone (Soucek et al. 2001) and as a part of an integrated multiple approach assessment (Soucek et al. 2000) to detect and monitor the 
effects of acid mine drainage in southwestern Virginia streams. In the present study, Corbicula fluminea growth rates (Table 10) were significantly less in 2006 than in 2005 $(P=0.0302)$ and $2007(1.14 \mathrm{~mm}, \mathrm{P}<0.0001)$ regardless of placement location. Clams placed at the reference site grew significantly larger compared to clams at all oil production site locations for the first two years of the study $(2005 \mathrm{P}<0.0001 ; 2006 \mathrm{P}<$ $0.0001 ; 2007 P=0.5948$ and transect two $P=0.4498)$. When all data from all years were combined, clams grown at the reference site grew more than those placed at the oil production site (submerged brine pit $\mathrm{P}<0.0001$ and transect $2 \mathrm{P}=0.0100$ ), but no differences were observed between locations at the oil production site $(P=0.4109)$.

\section{Task 3.0 - Comparison of laboratory and field data}

The laboratory bioassays of the produced water and water from some of the groundwater wells indicated the samples were acutely toxic to the standard laboratory test species used in the study. A pattern of groundwater contamination in association with the brine injection well and the predicted and laboratory-generated toxicity of that groundwater did indicate the potential for biotic effects if a sufficient volume of groundwater reached the sediment surface. Laboratory bioassays on sediment taken from the reference site and two locations at the oil production site did not indicate any negative effects associated with exposure to sediment from the oil production site (Figures 17 and 18), although the results of the in situ bioassays suggest a consistent negative effect on growth of both the amphipod, $\mathrm{H}$. azteca, and the Asian clam, $\mathrm{C}$. fluminea at the oil production site as compared to the reference site. Slight differences in the macrobenthic communities resident at the reference and oil production sites were also apparent, but these differences were not consistent with a negative impact at the production site, and in fact some attributes of the benthic community at the oil production site were indicative of a healthier benthic community than found at the reference site.

A direct link between produced water bioassays and field conditions would have been easier to make if a point source of produced water release existed. However, no clear indication of groundwater upwelling into the littoral zone of the lake could be established, and if this upwelling is occurring, it would most likely be a diffuse "nonpoint" input. It may also be that, if any upwelling of produced water did occur, it was restricted to times when water levels in the sub-littoral zone of the lake were particularly low and overall effects may be transient. In this regard, the use of longer-term in-situ and field evaluations may be important to integrate the transient stressors that could arise from occasional upwelling events.

Based on the existing literature, the results of experiments comparing laboratory bioassays, in situ experiments, and field studies vary greatly. Compared to laboratory bioassays, in situ exposures have been found to underestimate toxicity responses (Hose and Van den Brink 2004), overestimate toxicity responses (Sasson-Brickson and Burton 1991; Kater et al. 2001; Anderson et al. 2004), both over- and underestimate responses depending on the stressor (Tucker and Burton 1999), or agree with laboratory results (Schroer et al. 2004). Comparative studies have also found that effects measured in field experiments more closely resembled benthic community responses than laboratory bioassays, though laboratory studies are still relevant to field conditions (Hose and Van den Brink 2004; Ingersoll et al. 2005). 


\section{Conclusions}

Site produced water was found to be acutely toxic to aquatic test organisms at concentrations ranging from $1 \%$ to $10 \%$ of the whole produced water sample. As determined by toxicity identification evaluation and associated ion toxicity modeling, major ion salts and hydrocarbons were the primary mixture toxicants, and the salts were found to contaminate groundwater across the entire site. The standardized test species used in the laboratory bioassays (fathead minnows and daphnids) exhibited differences in sensitivity to these two general classes of contaminants, which underscores the importance of using multiple species when evaluating produced water toxicity.

Groundwater toxicity varied greatly between sampling wells ( $\mathrm{LC}_{50}$ 's ranged from $2.12 \%$ to over $100 \%$ ), but no seasonal pattern was detectable. The wells closest to the produced water injection well exhibited the greatest measured toxicity. Wells not near the injection well but located on a salt scar derived from an on-site evaporation pond also had toxicity greater than that found in wells located in a vegetated area, suggesting that contamination from both the injection well and evaporation pond contributed to measured groundwater effects. Toxicity modeling of groundwater ion profiles indicated the produced water injection well was probably the most significant contributor to groundwater toxicity. The use of the GIS model surfaces may facilitate study of produced water plumes at other contaminated oil production sites in which elevated ions are the primary source of effects, although toxicity testing is still necessary to detect the presence of other toxic groundwater constituents and validate predictions. In addition, another statistical technique, principle component analyses (PCA), proved useful for indicating dilution by lake water and possible biogeochemical reactions as possible factors that ameliorated groundwater toxicity.

Elevated concentrations of major ions were found in pore water from lake sediments, but toxicity from these ions appears limited to sediment depths of $10 \mathrm{~cm}$ or greater, which is outside of the primary zone of biological activity. Further, site sediments did not have any effects on test organisms during laboratory toxicity testing and macroinvertebrate communities did not indicate impairment at the oil production site as compared to a reference site. In situ experiments with amphipods and Asian clams did indicate a sublethal site effect, but these could not be definitively linked with produced water infiltration.

Due to the lack of clear evidence of produced water infiltration into the sub-littoral zone of the lake, it is not possible to assess whether the laboratory bioassays of produced water effectively indicate risk in the receiving system. However, the acutely toxic nature of the produced water and general lack of biological effects in the lake at the oil production site do further support the idea that the degree of produced water infiltration into surficial lake sediments and the near-shore water column is not very extensive. This study was able to demonstrate the utility of ion toxicity modeling to support data from toxicity identification evaluations aimed at identifying key toxic constituents in produced water. This information could be used to prioritize options for treating produced water in order to reduce toxic constituents and enhance options for reuse. The study also demonstrated how GIS, toxicity modeling, and toxicity assessment could be used to facilitate future site assessments. 


\section{References}

ALL Consulting. 2003. Handbook on Coal Bed Methane Produced Water: Management and Beneficial Use Alternatives. ALL Consulting, Tulsa, OK. Available online at: http://www.ALL-LLC.com.

Atkinson, J. F., M. R. Matsumoto, M. D. Bunn, and D. S. Hodge. 1992. Use of solar ponds to reclaim salt products from brine waters from oil and gas well operations in New York. In Produced Water, J. P. Ray and F. R. Engelhart, eds. Plenum Press, New York, Pp. 535-547.

Boelter, A. M., F. N. Lamming, A. M. Farag, and H. L. Bergman. 1992. Environmental effects of saline oil-field discharges on surface waters. Environmental Toxicology and Chemistry 11: 1187-1195.

Burton Jr., G. A. 1991. Assessment of freshwater sediment toxicity. Environmental Toxicology and Chemistry 10: 1585-1627.

Burton Jr., G. A., M. S. Greenberg, C. D. Rowland, C. A. Irvine, D. R. Lavoie, J. A. Brooker, L. Moore, D. F. N. Raymer, and R. A. McWilliam. 2005. In situ exposures using caged organisms: a multi-compartment approach to detect aquatic toxicity and bioaccumulation. Environmental Pollution 134: 133-144.

Cairns, J. Jr., J.R. Bidwell, and M.E. Arnegard. 1996. Toxicity testing with communities: microcosms, mesocosms and whole system manipulations. Reviews of Environmental Contamination and Toxicology 147:45-69.

Carter, J. L., V. H. Resh, M. J. Hannaford, and M. J. Meyers. 2006. Macroinvertebrates as biotic indicators of environmental quality. Chapter 30 in F. R. Hauer and G. A. Lamberti, eds. Methods in stream ecology. Academic Press, San Diego, CA.

Cataldo, D. H., D. Boltovskoy, J. Stripeikis, and M. Pose. 2001. Condition index and growth rates of field caged Corbicula fluminea (Bivalvia) as biomarkers of pollution gradients in the Paraná river delta (Argentina). Aquatic Ecosystem Health and Management 4: 187-201.

Chapman, P.M. 1989. Current approaches to developing sediment quality criteria. Environmental Toxicology and Chemistry 8: 589-599.

Clemens, H.P. and W.H. Jones. 1954. Toxicity of brine water from oil wells. Transactions of the American Fisheries Society 84:97-109.

Collins, A.G., 1985, Geochemistry of Oilfield Waters: Developments in Petroleum Science 1: New York, Elsevier Scientific Publishing Company. Cover, E. C. and R. C. Harrel. 1978. Sequences of colonization, diversity, biomass, and productivity of macroinvertebrates on artificial substrates in a freshwater canal. Hydrobiologia 59: 8195. 
Cover, E.C. and R.C. Harrel. 1978. Sequences of colonization, diversity, biomass, and productivity of macroinvertebrates on artificial substrates in a freshwater canal. Hydrobiologia 59: 81-95.

Dalmacija, B., E. Kalrlovic, Z. Tamas, and D. Miskovic. 1996. Purification of highsalinity wastewater by activated sludge process Water Research 30: 295-298.

Daly, D.J., and Mesing, G.E., 1995, Atlas of Gas Related Produced Water for 1990: Chicago, Gas Research Institute Topical Report 95/0016.

Di Toro, D.M., C.S. Zarba, D.J. Hansen, W.J. Berry, R.C. Swartz, C.E. Cowan, S.P. Pavlou, H.E. Allen, N.A. Thomas, and P.R. Paquin. 1991. Technical basis for establishing sediment quality criteria for nonionic chemicals using equilibrium partitioning. Environmental Toxicology and Chemistry 10: 1541-1583.

Doherty, F. G. 1990. The Asiatic clam, Corbicula spp., as a biological monitor in freshwater environments. Environmental Monitoring and Assessment 15: 143-181.

Douglas, W. S. and J. A. Veil. 1996. Do produced water toxicity tests accurately measure produced water toxicity in marine environments? 3rd International Petroleum Environmental Conference, ANL/EA/CP--89257, CONF-9609237--4.

Elias-Samlalsingh, N. and J. B. R. Agard. 2004. Application of toxicity identification evaluation procedures for characterizing produced water using the tropical mysid, Metamysidopsis insularis. Environmental Toxicology and Chemistry 23: 1194-1203.

Epler, J. H. 2001. Identification manual for the larval Chironomidae (Diptera) of North and South Carolina. St. Johns River Water Management District Special Publication SJ2001-SP13.

Fucik, K. W. 1992. Toxicity identification evaluation and characteristics of produced water discharges from Colorado and Wyoming. In Produced Water, J. P. Ray and F. R. Engelhart, eds. Plenum Press, New York, Pp. 187-198.

Ganjegunte G. K., G. F. Vance, and L. A. King. 2005. Soil chemical changes resulting from irrigation with water co-produced with coalbed natural gas. Journal of Environmental Quality 34: 2217-2227.

Gulley, D. D., D. R. Mount, J. R. Hockett, and H. L. Bergman. 1992. A statistical model to predict toxicity of saline produced waters to freshwater organisms. In Produced Water, J. P. Ray and F. R. Engelhart, eds. Plenum Press, New York, Pp. 89-96.

GWPC. 2002. Ground Water Protection Council Produced Water Conference, Oct. 1617, Colorado Springs, CO. Papers available online at: http://www.gwpc.org/Meetings/PW2002/Papers-Abstracts.htm. 
Henderson, S.B., S.W.J. Grigson, P. Johnson, and B.D. Roddie. 1999. Potential impact of production chemicals on the toxicity of produced water discharges from North Sea oil platforms. Marine Pollution Bulletin 38:1141-1151.

Herkelrath, W.N. and Y.K. Kharaka. 2002. Hydrologic controls on the subsurface transport of oil-field brine at the Osage-Skiatook Petroleum Research "B" Site, Oklahoma. Proceedings of the Ninth Annual International Petroleum Environmental Conference, Integrated Petroleum Environmental Consortium, Albuquerque, NM.

Ho, K. and D. Caudle. 1997. Ion toxicity and produced water, Letter to the Editor. Environmental Toxicology and Chemistry 16:1993-1995.

Hose G.C. and P.J. Van den Brink. 2004. Confirming the species-sensitivity distribution concept for endosulfan using laboratory, mesocosm, and field data. Archives of Environmental Contamination and Toxicology 47: 511-520.

Hudak, P.F. and S. Blanchard. 1997. Land use and groundwater quality in the Trinity group outcrop of north-central Texas, USA. Environment International 23: 507-517.

Ingersoll, C.G., N. Wang, J.M.R. Hayward, J.R. Jones, S.B. Jones, and D.S. Ireland. 2005. A field assessment of long-term laboratory sediment toxicity tests with the amphipod Hyallela azteca. Environmental Toxicology and Chemistry 24: 2853-2870.

Jackson, L. and J. Meyers. 2002. Alternative use of produced water in aquaculture and hydroponic systems at Naval Petroleum Reserve No. 3. Paper presented at the 2002 Ground Water Protection Council Produced Water Conference, Oct. 16-17, Colorado Springs, CO. (Paper available online at: http://www.gwpc.org/Meetings/PW2002/Papers-Abstracts.htm).

Kater, B.J., J.F. Postma, M. Dubbledam, and J.T.H.J. Prins. 2001. Comparison of laboratory and in situ sediment bioassays using Corphium volutator. Environmental Toxicology and Chemistry 20: 1291-1295.

Kefford, B. J. 2000. The effect of saline water disposal: implications for monitoring programs and management. Environmental Monitoring and Assessment 63: 313-327.

Kharaka, Y.K., J.J. Thordsen, E. Kakouros, and M.M. Abbott. 2002. Environmental impacts of petroleum production: fate of inorganic and organic chemicals in produced water from the Osage-Skiatook Petroleum Environmental Research sites, Osage County, Oklahoma. Proceedings of the Ninth Annual International Petroleum Environmental Conference, Integrated Petroleum Environmental Consortium, Albuquerque, NM.

Kharaka, Y. K., J. J. Thordsen, E. Kakouros, and W. N. Herkelrath. 2005. Impacts of petroleum production on ground and surface waters: results from the Osage-Skiatook 
petroleum environmental research A site, Osage county, Oklahoma. Environmental Geosciences 12: 127-138.

Krause, P.R. 1995. Spatial and temporal variability in receiving water toxicity near an oil effluent discharge site. Archives of Environmental Contamination and Toxicology 29: 523-529.

Mancini, E. R. and C. T. Stillwell. 1992. Biotoxicity characterization of a producedwater discharge in Wyoming. Journal of Petroleum Technology 44: 744-748.

Marshall N. A. and P. C. E. Bailey. 2004. Impact of secondary salinisation on freshwater ecosystems: effects of contrasting, experimental, short-term releases of saline wastewater on macroinvertebrates in a lowland stream. Marine and Freshwater Research 55: 509-523.

Mendelssohn, I.A., K.M. Flynn, and B.J. Wilsey. 1990. The relationship between produced water discharges and plant biomass and species composition in 3 Louisiana marshes. Oil \& Chemical Pollution 7: 317-335.

Merrit, R. W. and K. W. Cummins. 1996. An introduction to the aquatic insects of North America, 3rd ed. Kendall/Hunt Publishing Company, Dubuque, IA.

Moraes, J. E. F., D. N. Silva, F. H. Quina, O. Chiavone-Filho, and C. A. O. Nascimento. 2004. Utilization of solar energy in the photodegredation of gasoline water and oil-fieldproduced water. Environmental Science and Technology 38: 3746-3751.

Mount, D. R., K. R. Drottar, D. D. Gulley, J. P. Fillo, and P. E. O'Neil. 1992. Use of laboratory toxicity data for evaluating the environmental acceptability of produced water discharge to surface waters. In Produced Water, J. P. Ray and F. R. Engelhart, eds. Plenum Press, New York, Pp. 175-185.

Mount, D. R., D. D. Gulley, J. R. Hockett, T. D. Garrison, and J. M. Evans. 1997. Statistical models to predict the toxicity of major ions to Ceriodaphnia dubia, Daphnia magna and Pimephales promelas (fathead minnows). Environmental Toxicology and Chemistry 16: 2009-2019.

Okandan, E., F. Gumrah, and B. Demiral. 2001. Pollution of an aquifer by produced oil field water. Energy Sources 23: 327-336.

Olive J. H., J. L.Jackson, D. Keller, and P. Wetzel. 1992. Effects of oil-field brines on biological integrity of 2 tributaries of the Little Muskingum Ruver, Southeastern Ohio. Ohio Journal of Science 92: 139-146.

O'Neil, P. E. S. C. Harris, M. F. Mettee, H. R. Isaacson, and J. M. Evans. 1992a. Biological fate and effect of coalbed methane produced waters discharged into streams 
of the Warrior Basin, Alabama. In Produced Water, J. P. Ray and F. R. Engelhart, eds. Plenum Press, New York, Pp. 315-327.

O'Neil, P. E., H. R. Isaacson, and J. M. Evans. 1992b. Surface discharge of coalbed methane produced waters in the Warrior Basin of Alabama, the Cedar Cove model. In Produced Water, J. P. Ray and F. R. Engelhart, eds. Plenum Press, New York, Pp. 329-341.

Peeters E. T. H. M., J. J. P. Gardeniers, and A. A. Koelmans. 2000. Contribution of trace metals in structuring in situ macroinvertebrate community composition along a salinity gradient. Environmental Toxicology and Chemistry 19: 1002-1010.

Produced Waters Database. 2002. Accessed online at: http://energy.cr.usgs.gov/prov/prodwat/ 15 April 2004.

Ramirez, P., Jr. 1993. Contaminants in oil field produced waters discharged into the Loch Katrine wetland complex, Park County, Wyoming and their bioconcentration in the aquatic bird food chain: U.S. Fish and Wildlife Service Contaminant Report Number R6/706C/93, 37 p.

Reed, D.C., R.J. Lewis, and M. Anghera. 1994. Effects of an open coast oil production outfall on patterns of giant kelp (Macrocyctis pyrifera) recruitment. Marine Biology 120: 25-31.

Rosenberg, D. M. and V. H. Resh. 1982. The use of artificial substrates in the study of freshwater benthic macroinvertebrates. In Artificial Substrates, J. Cairns Jr. ed., Ann Arbor Science, Ann Arbor, Pp.175-235.

Rosenberg, D. M. and V. H. Resh. 1993. Introduction to freshwater biomonitoring and benthic macroinvertebrates. In Freshwater Biomonitoring and Benthic Macroinvertebrates, D. M. Rosenberg and V. H. Resh, eds. Chapman and Hall, New York, pp. 1-9.

Sadiq, M. and I. Alam. 1997. Metal concentrations in a shallow groundwater aquifer underneath petrochemical complex. Water Resources 31: 3089-3097.

Sasson-Brickson, G. and G.A. Burton, Jr. 1991. In situ and laboratory sediment toxicity testing with Ceriodaphnia dubia. Environmental Toxicology and Chemistry 10: 201-207.

Sauer, T. C., H. J. Costa, J. S. Brown, and T. J. Ward. 1997. Toxicity identification evaluations of produced-water effluents. Environmental Toxicology and Chemistry 16: 2020-2028.

Schiff, K. C., D. J. Reish, J. W. Anderson, and S. M. Bay. 1992. A comparative evaluation of produced water toxicity. In Produced Water, J. P. Ray and F. R. Engelhart, eds. Plenum Press, New York, Pp. 199-207. 
Schroer, A.F.W., J.D.M. Belgers, T.C.M. Brock, A.M. Matser, S.J. Maund, and P.J. Van den Brink. 2004. Comparison of laboratory single species and field population-level effects of the pyrethroid insecticide $\lambda$-Cyhalothrin on freshwater invertebrates. Archives of Environmental Contamination and Toxicology 46: 324-335.

Shobanov, N.A., I.I. Kiknadze, and M.G. Butler. 1999. Palearctic and Nearctic Chironomus (Camptochironomus) tentans (Fabricus) are different species (Diptera: Chironomidae). Entomologica Scandinavica 30: 311-322.

Short, T.M., J.A. Black, and W.J. Birge. 1991. Ecology of a saline stream: community responses to spatial gradients of environmental conditions. Hydrobiologia 226: 167178.

Smith, D. G. 2001. Pennak's freshwater invertebrates of the United States, 4th ed. John Wiley and Sons, New York.

Smith, J. P., A. O. Tyler, and Z. A. Sabeur. 1998. Ecological assessment of produced waters in Indonesia. Environmental Toxicology and Water Quality 13: 323-336.

Soucek, D. J., D. S. Cherry, R. J. Currie, H. A. Latimer, and G. C. Trent. 2000. Laboratory to field validation in an integrative assessment of an acid mine drainageimpacted watershed. Environmental Toxicology and Chemistry 19: 1036-1043.

Soucek, D. J., T. S. Schmidt, and D. S. Cherry. 2001. In situ studies with Asian clams (Corbicula fluminea) detect acid mine drainage and nutrient inputs in low-order streams. Canadian Journal of Fisheries and Aquatic Sciences 58: 602-608.

Stephenson, M. T. 1992. A survey of produced water studies. In Produced Water, J. P. Ray and F. R. Engelhart, eds. Plenum Press, New York, Pp. 1-11.

Stromgren, T., S. E. Sorstrom, L. Schou, I. Kaarstad, T. Aunaas, O. G. Brakstad, and O. Johansen. 1995. Acute toxic effects of produced water in relation to chemical composition and dispersion. Marine Environmental Research 40: 147-169.

Thurston, R. V., R.C. Russo, and G. A. Vinogradov. 1981. Ammonia toxicity to fishes. Effect of $\mathrm{pH}$ on the toxicity of the unionized ammonia species. Environmental Science and Technology 15: 837-840.

Tietge, J. E., J. R. Hockett, and J. M. Evans. 1997. Major ion toxicity of six produced waters to three freshwater species: application of ion toxicity models and TIE procedures. Environmental Toxicology and Chemistry 16: 2002-2008.

Tucker, K.A. and G.A. Burton, Jr. 1999. Assessment of nonpoint-source runoff in a stream using in situ and laboratory approaches. Environmental Toxicology and Chemistry 18: 2797-2803. 
U.S. Environmental Protection Agency. 1991. Methods for aquatic toxicity identification evaluations: phase I toxicity identification procedures, 2nd ed. EPA/600/6-91/003. Washington, DC.

U.S. Environmental Protection Agency. 2000. Methods for measuring the toxicity and bioaccumulation of sediment-associated contaminants with freshwater invertebrates. EPA/600/R-99/064. Duluth, MN.

U.S. Environmental Protection Agency. 2002a. Methods for measuring the acute toxicity of effluents and receiving waters to freshwater and marine organisms. EPA/821/R-02/012. Washington, DC.

U.S. Environmental Protection Agency. 2002b. Short-term methods for estimating the chronic toxicity of effluents and receiving waters to freshwater organisms. EPA/821/R02/013. Washington, DC.

Veil, J. A., B. G. Langhus, and S. Belieu. 1999. DOWS reduce produced water disposal costs. Oil and Gas Journal 76-85.

Veil, J.A. 2003. Innovative technologies for managing oil field wastes. Journal of Energy Resources Technology, 125: 238-248.

Washburn, L., S. Stone, and S. Maclntyre. 1999. Dispersion of produced water in a coastal environment and its biological implications. Continental Shelf Research 19: 5778.

Wiebe, A.H., J.G. Burr, and H.E. Faubion. 1924. The problem of stream pollution in Texas with special reference to salt water from the oil fields. Transactions of the American Fisheries Society 64: 81-85.

Woolard, C. R. and R. L. Irvine. 1995. Treatment of hypersaline wastewater in the sequencing batch reactor. Water Research 29: 1159-1168. 


\section{Graphical Materials List List of Figures}

Figure 1. Location of Skiatook Lake in Oklahoma and the two USGS Osage-Skiatook Petroleum Environmental Research field sites. .32

Figure 2. Topographic map of the oil production site ……................................................

Figure 3. Major ions and basic water quality measures of produced water from December 2006 to September 2007.

Figure 4. Hydrocarbon concentrations of produced water from December 2006 to September 2007.

Figure 5. Skiatook Lake levels during the study period....................................................... 36

Figure 6. The oil production site during drought conditions that occurred over the summer and fall of 2006

Figure 7. The oil production site during rising lakes levels over the summer of 2007..............38

Figure 8. Principle component analysis symmetric biplot of groundwater well major ion profiles

Figure 9. Conductivity at the sediment-water interface along the four transects at the impact site.

Figure 10. Median effects concentrations for acute survival tests and chronic survival, reproduction, and growth tests from laboratory bioassays of produced water.

Figure 11. Observed 48-h LC 50 's for the two northernmost groundwater wells, located downgradient from the brine injection well.

Figure 12. Observed 48-h $\mathrm{LC}_{50}$ 's for the three central groundwater wells ...............................43

Figure 13. Observed 48-h LC $_{50}$ 's for the three southernmost groundwater wells .......................44

Figure 14. Surface conductivity at the oil production site observed using a GEM2 ...................45

Figure 15. Comparison of $\mathrm{LC}_{50}$ 's measured from standardized toxicity tests (48-h Daphnia magna) on selected groundwater wells and $\mathrm{LC}_{50}$ 's derived from an ion toxicity model.......46

Figure 16. Major ion toxicity contribution to produced water toxicity .....................................47

Figure 17. Relations between hydrocarbons and toxicity units (TU's) after major ion effects are

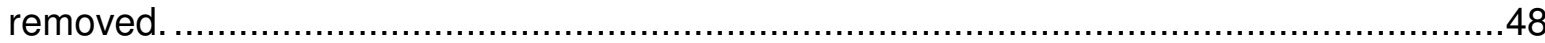

Figure 18. Mean abundance for macroinvertebrates from each sampling location where significant differences were detected.

Figure 19. Mean survival (top row) and growth (bottom row) or midges in laboratory experiments (left column) and in situ chambers .........................................................................50

Figure 20. Growth of amphipods in laboratory experiments during the Fall of 2007. ................51

Figure 21. Growth of amphipods in in situ chambers during the Fall of 2007...........................52

\section{List of Tables}

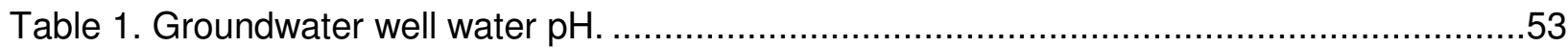

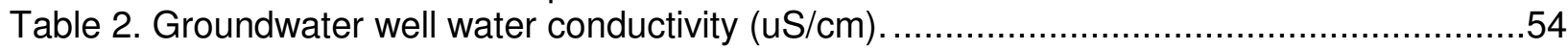

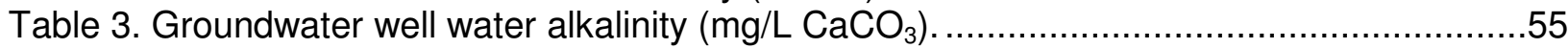

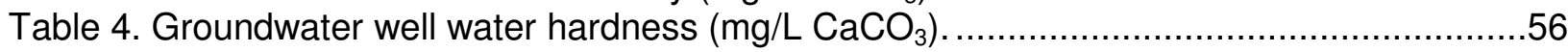

Table 5. Conductivity and $\mathrm{pH}$ of pore water samples taken..............................................57

Table 6. Ion concentrations of pore water samples for each sampling location. .......................58

Table 7. Estimates (worst-case)/best case of potential major ion toxicity to Daphnia magna using pore water ion profiles.................................................................................5

Table 8. Effects of TIE manipulations on produced water toxicity to D. pulex ..........................60

Table 9. Summary of macroinvertebrate samples. ...........................................................61

Table 10. Growth rates (mm/30 days) of Asian clams from in situ growth experiments. ............61 


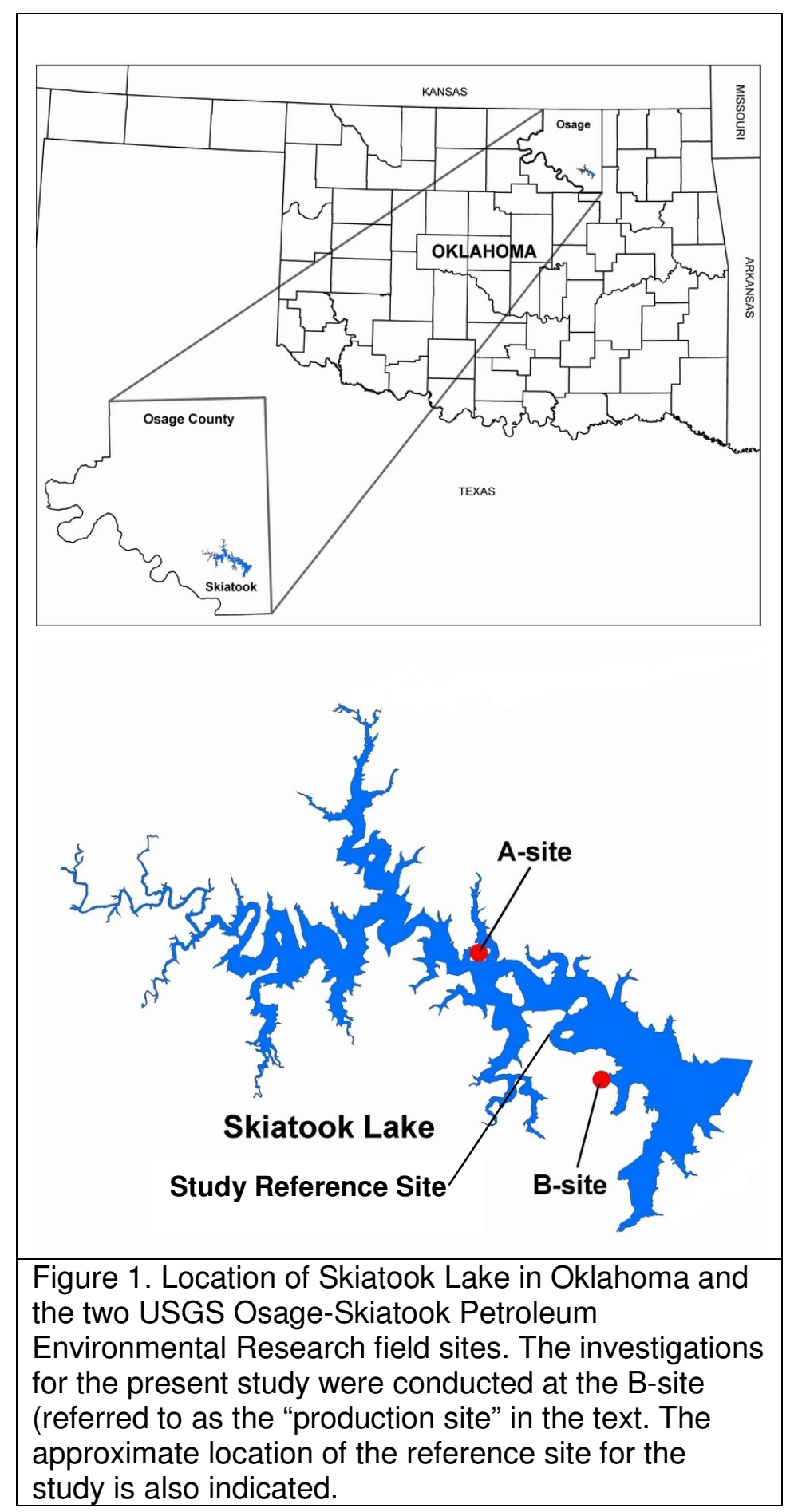




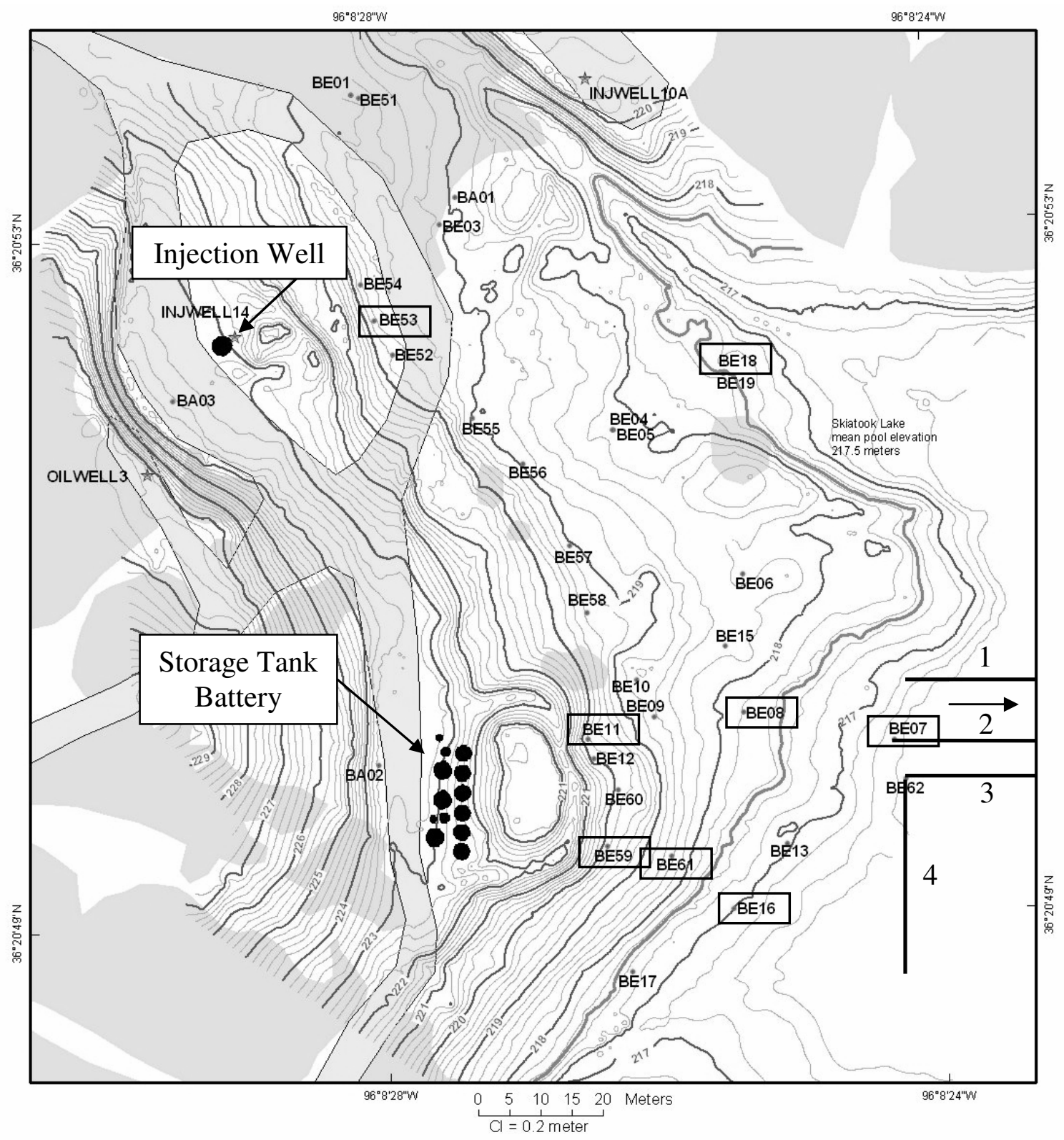

Figure 2. Topographic map of the oil production site, courtesy of USGS. Solid black circles indicate storage tanks and labeled black dots indicate groundwater wells. Black boxes indicate wells designated for acute toxicity monitoring. The four numbered lines originating from wells BE07, BE62, and just north of BE07 indicate the locations of sample transects. An arrow between transects 1 and 2 indicates the location (off of this map) of the submerged brine pit. 


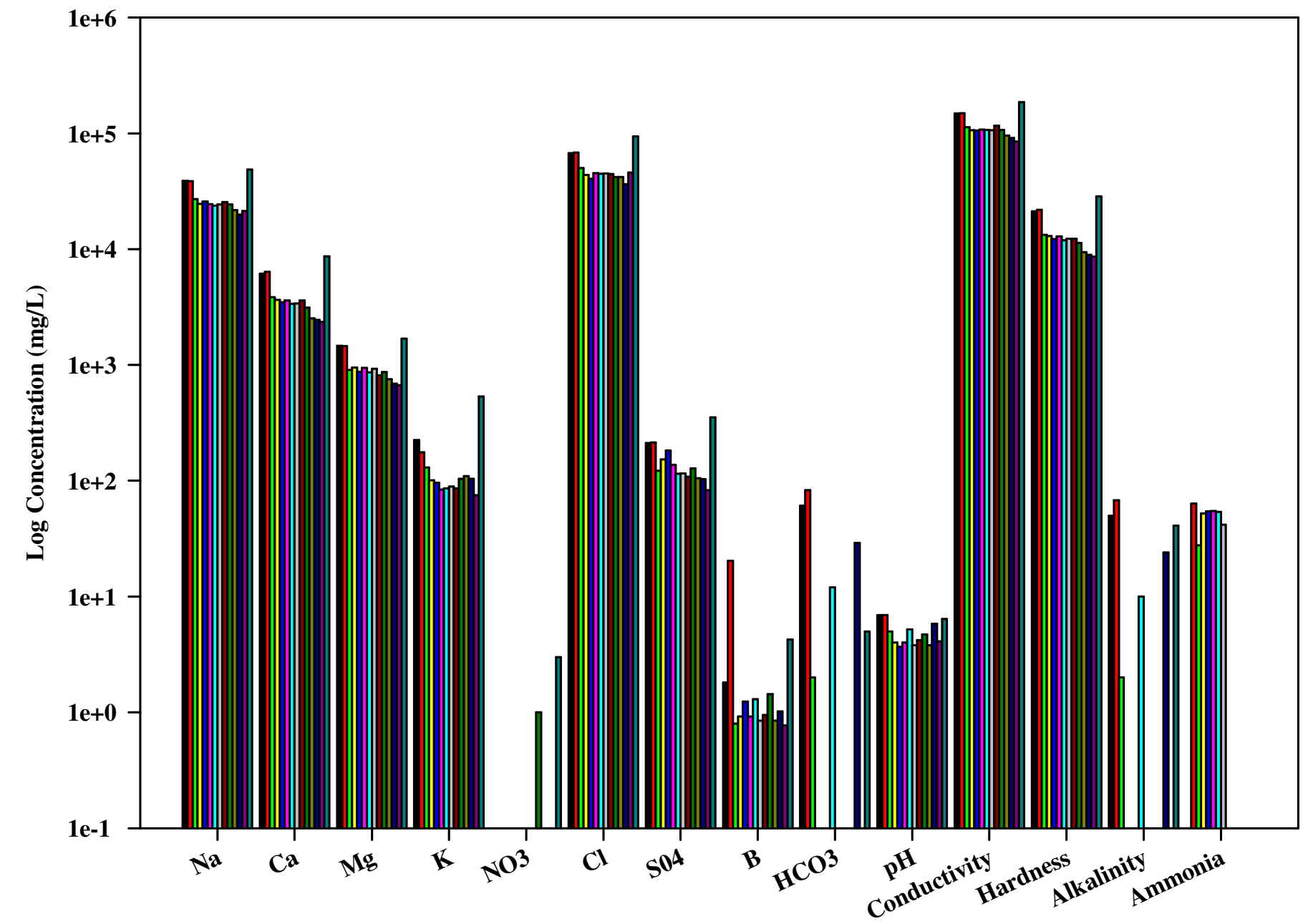

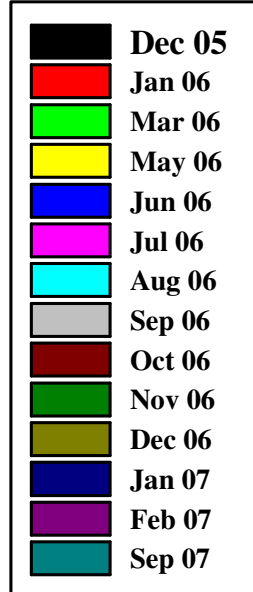

Figure 3a. Major ions and basic water quality measures of produced water from December 2005 to September 2007.

Figure 3. Major ions and basic water quality measures of produced water from December 2006 to September 2007. 


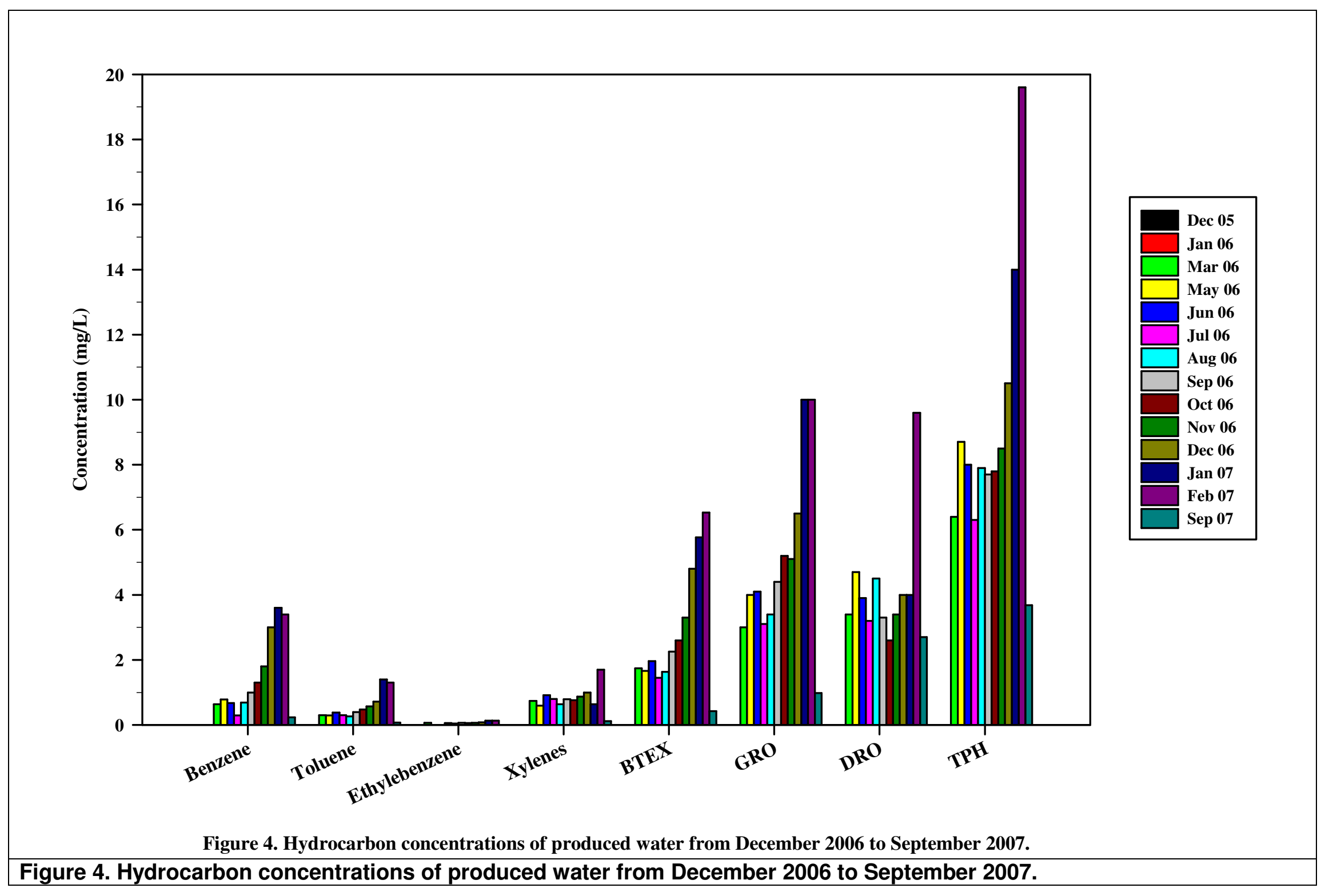




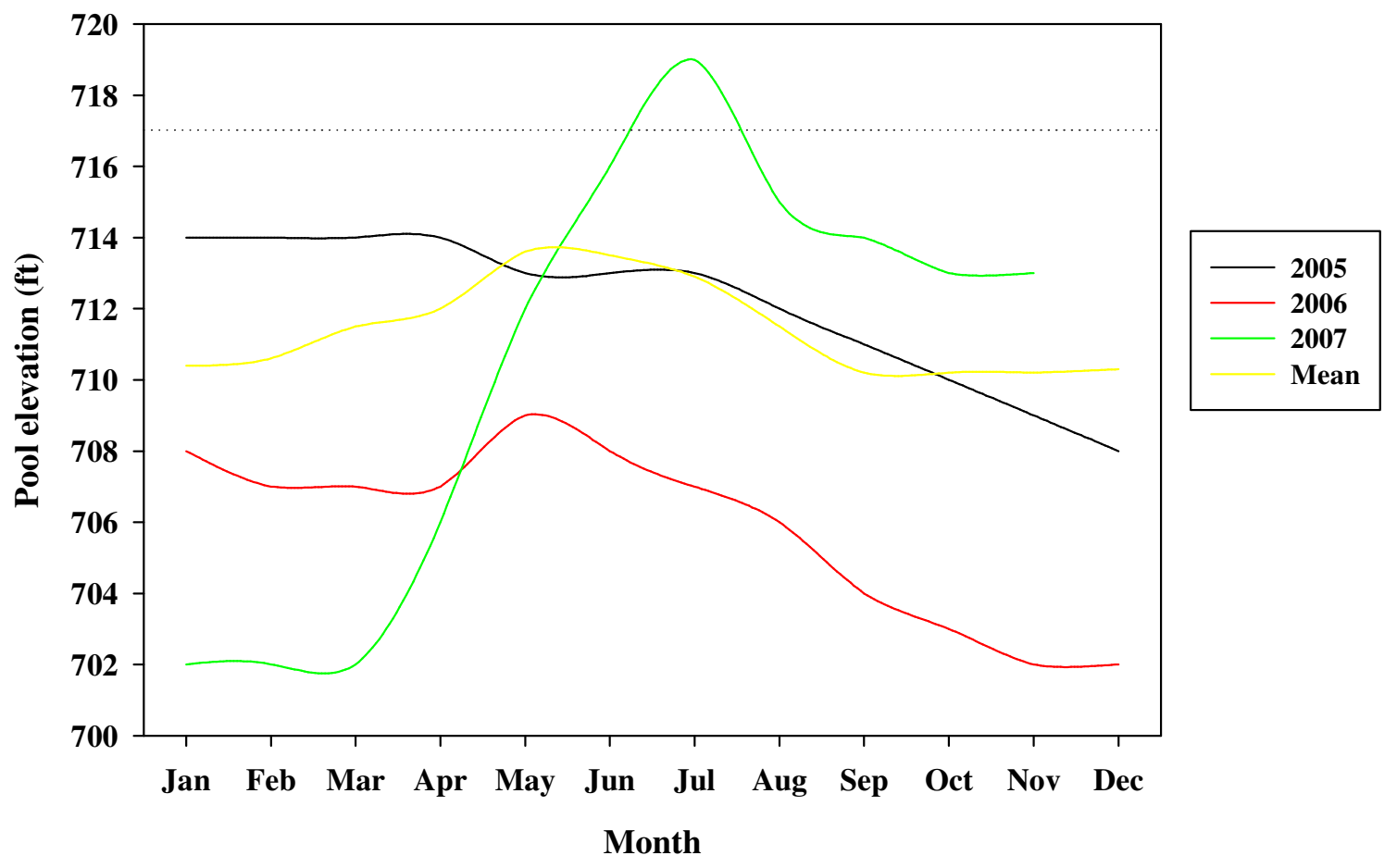

Figure 5. Skiatook Lake levels during the study period. Elevation levels are in feet above sea level and 714 feet is the conservation pool elevation. A dashed line indicates the pool elevation at which most of the ground water wells were contained within the lake. 


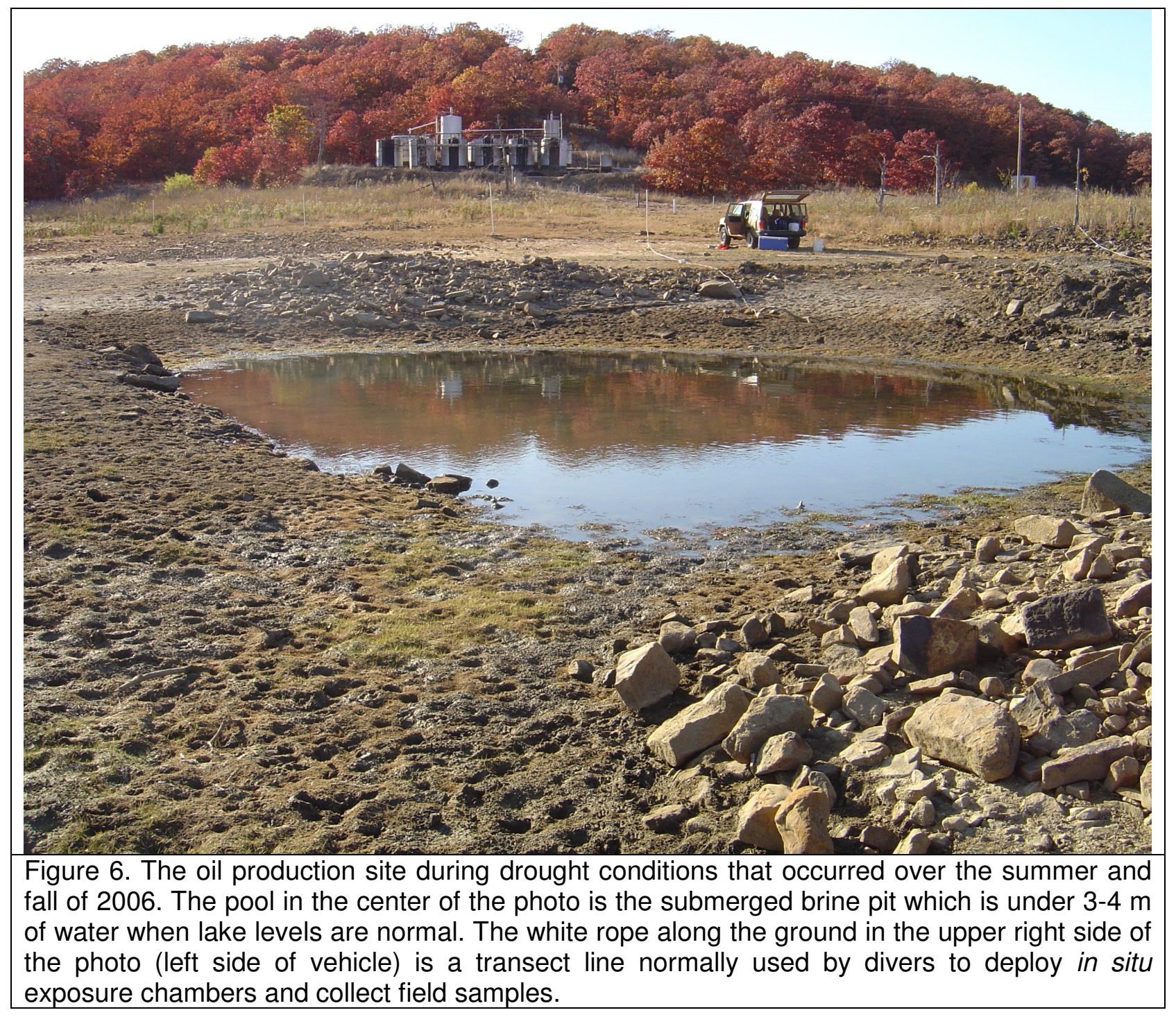




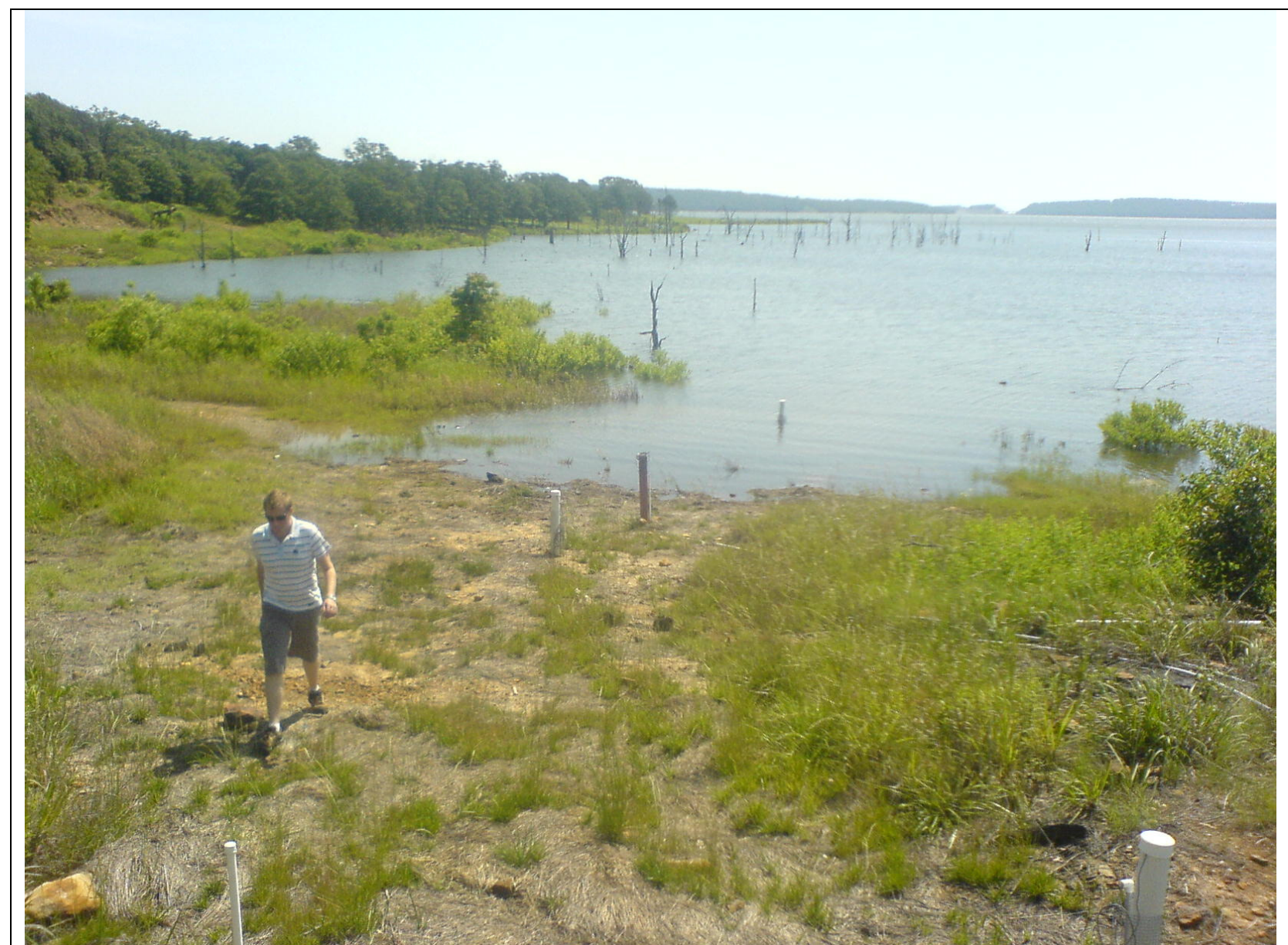

Figure 7. The oil production site during rising lakes levels over the summer of 2007. This photo was taken on 6 June 2007 and lake levels did not peak until early July. At that time, the majority of the groundwater sampling wells were submerged. 


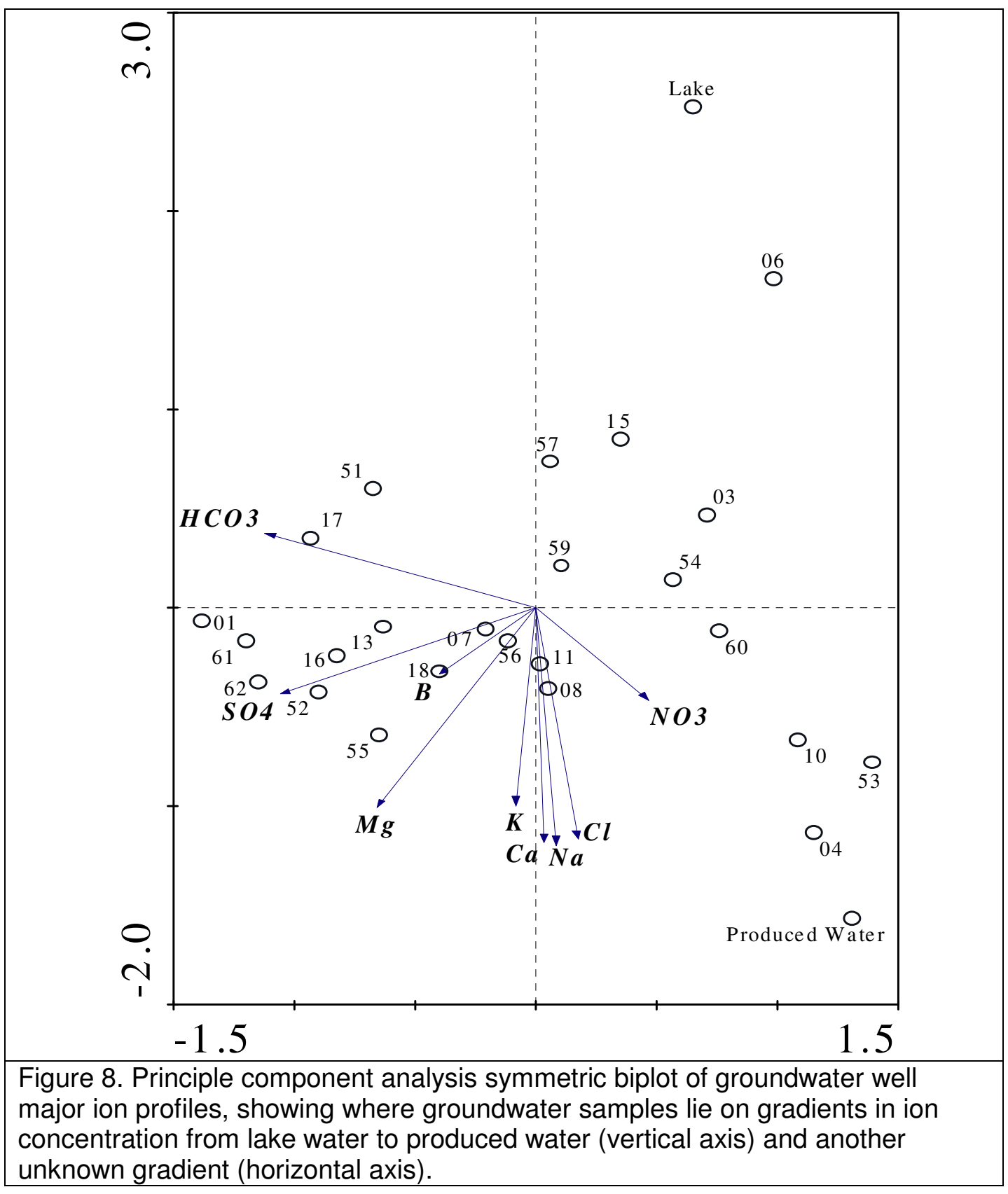




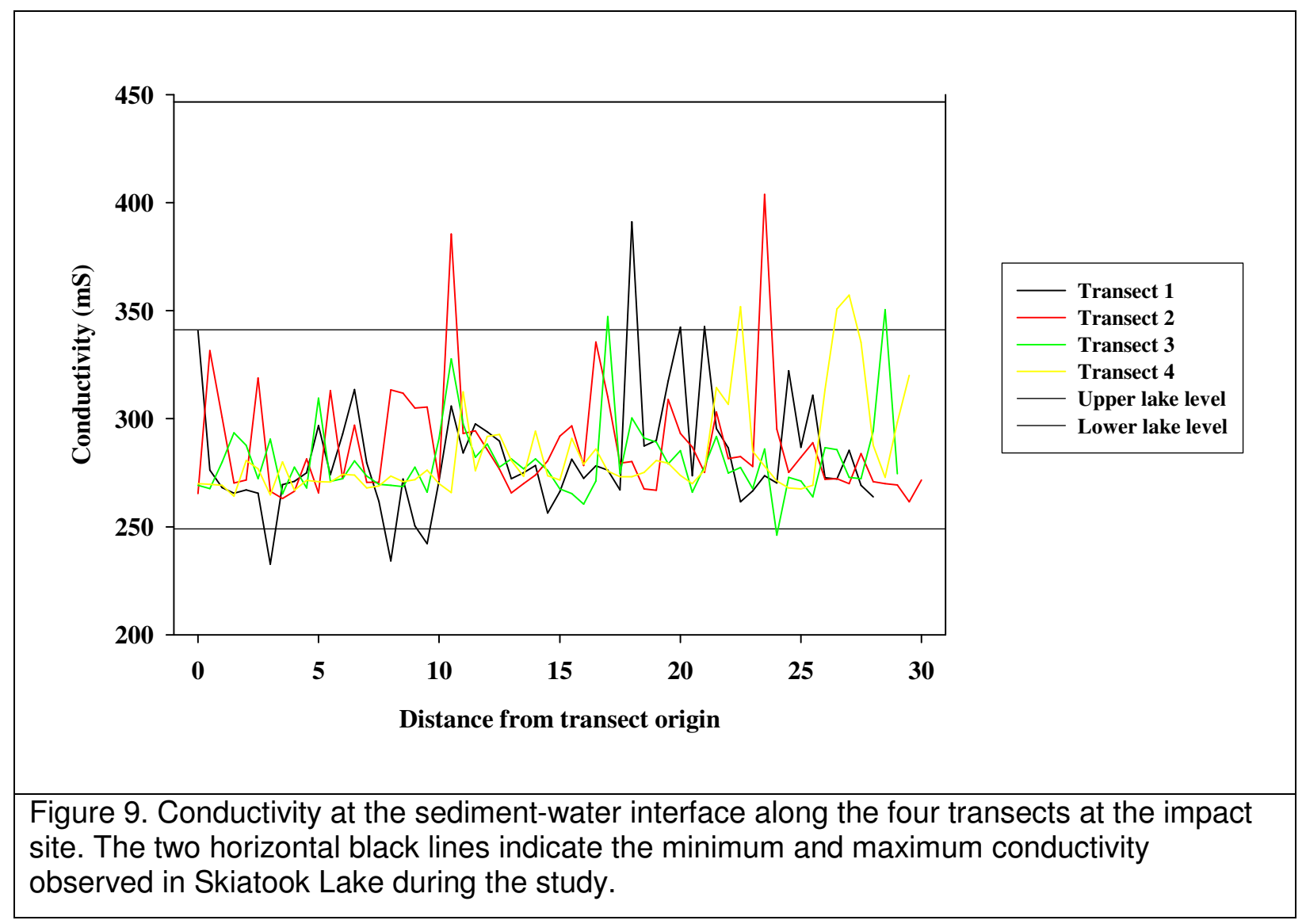




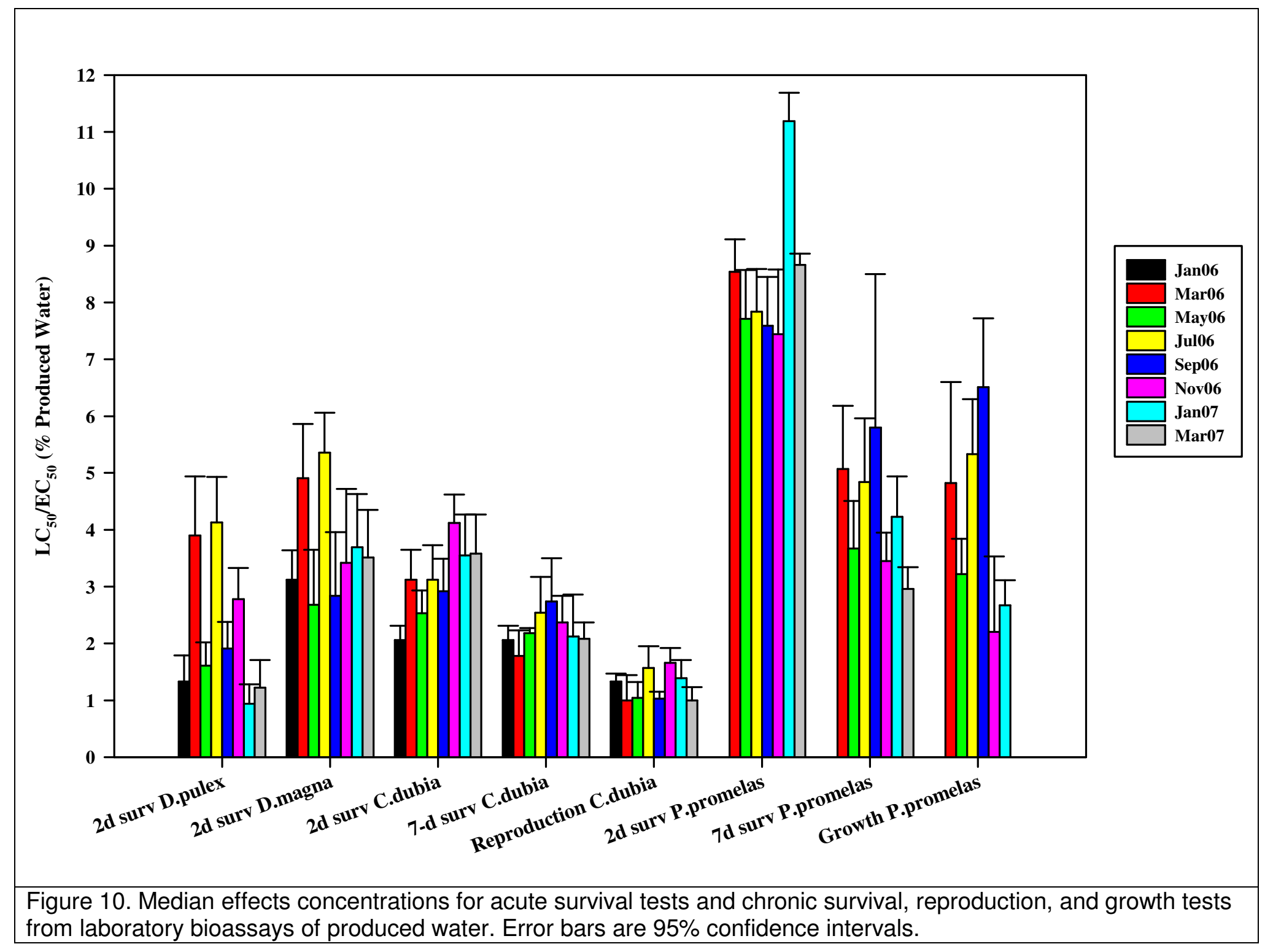




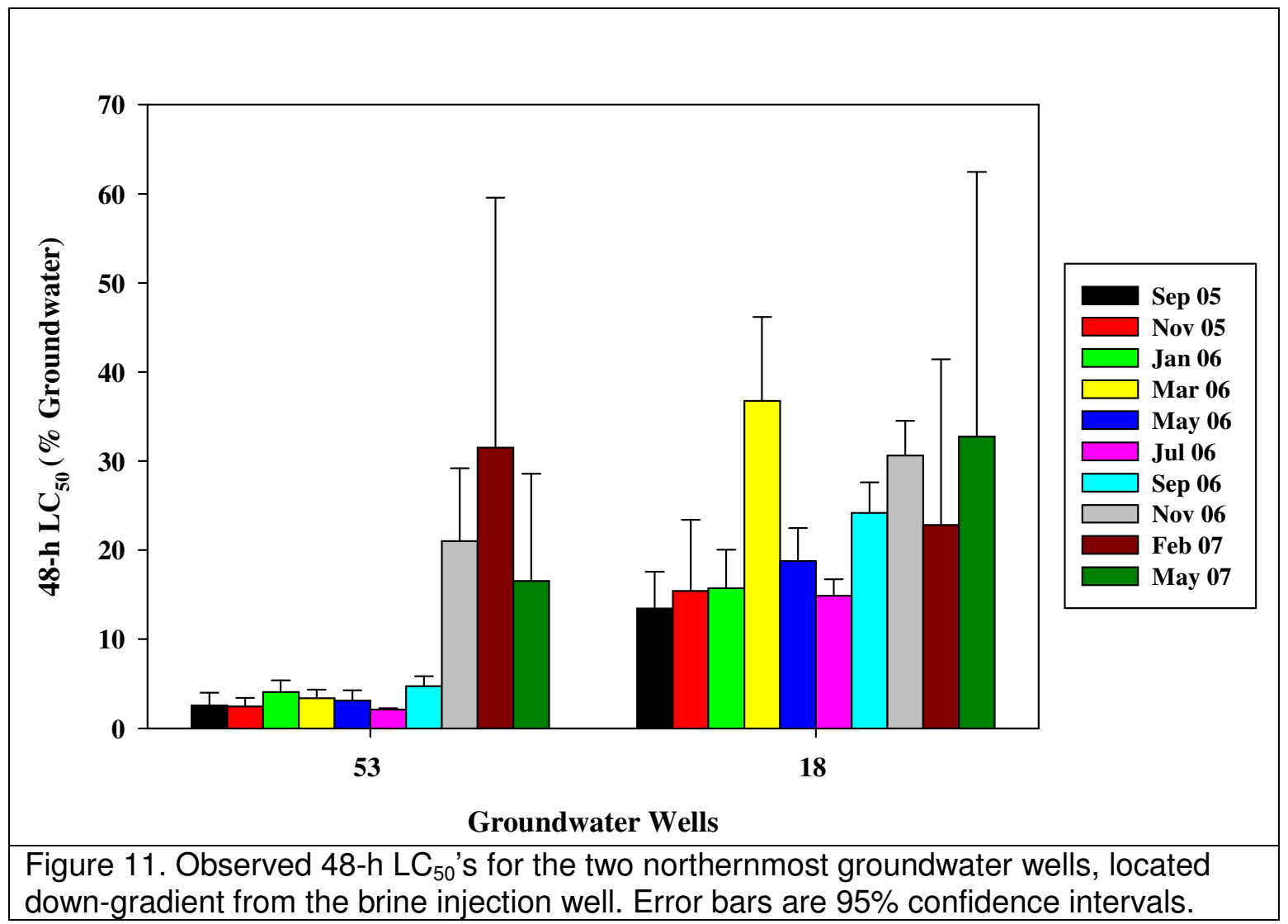




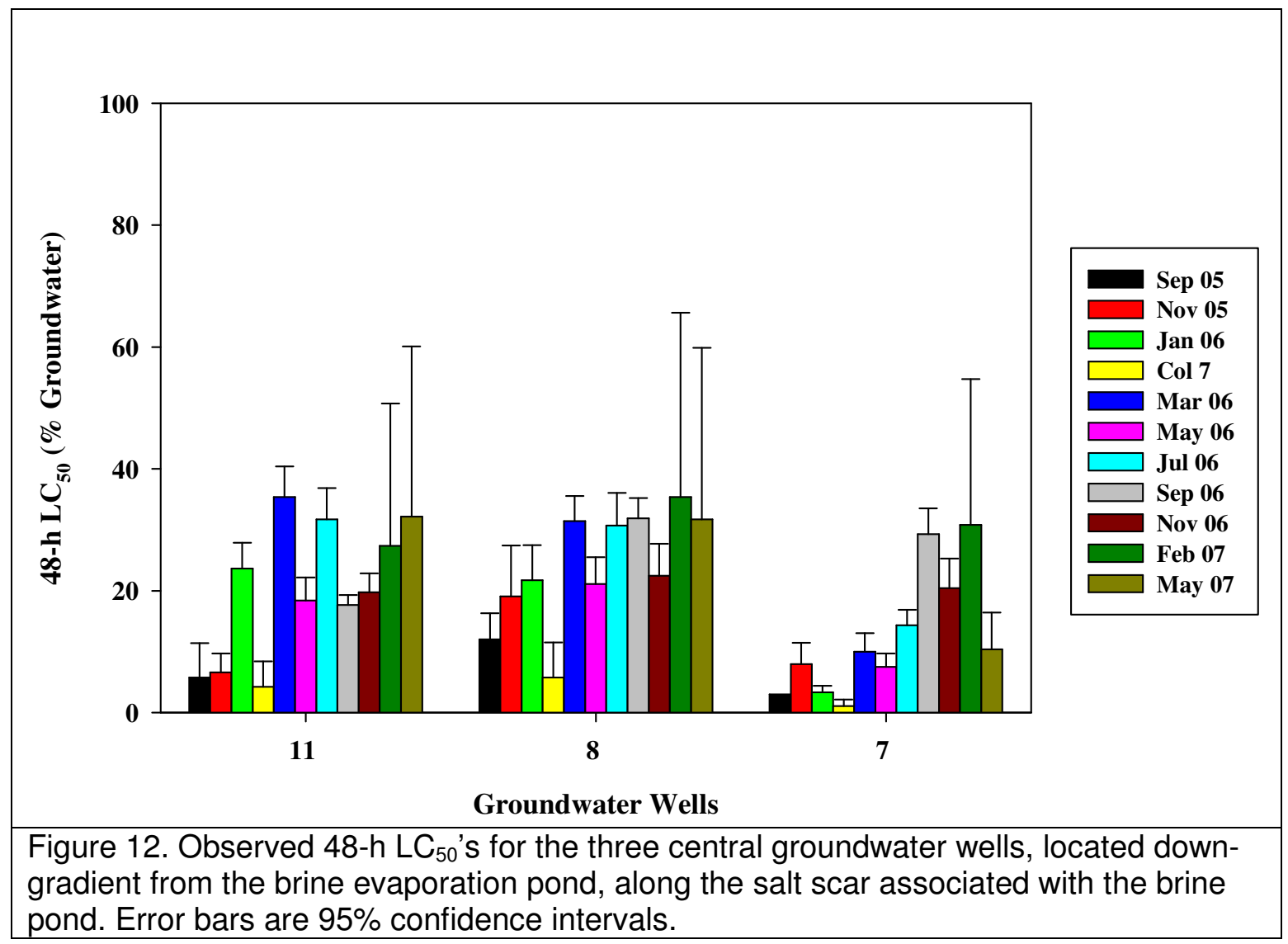




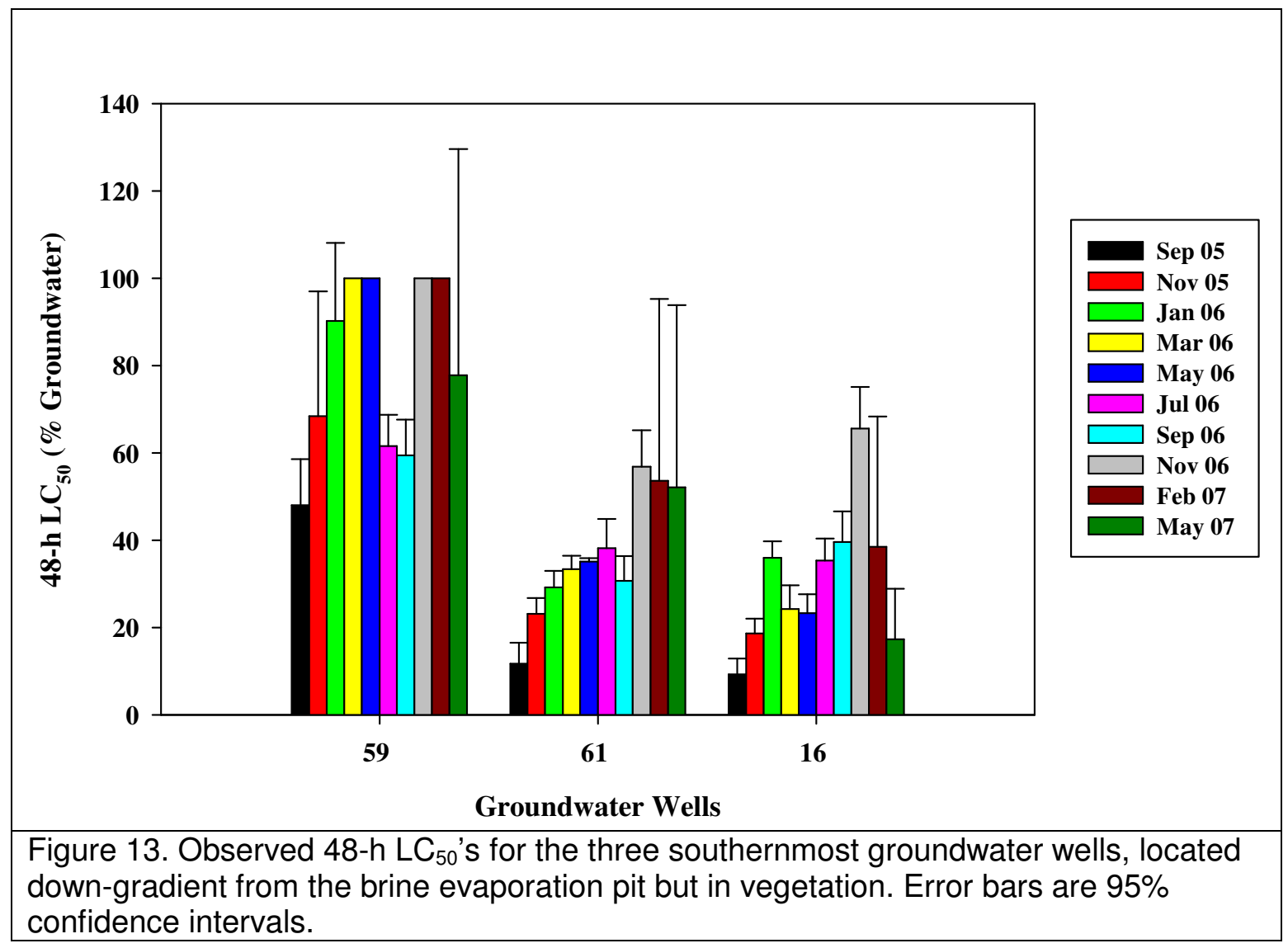




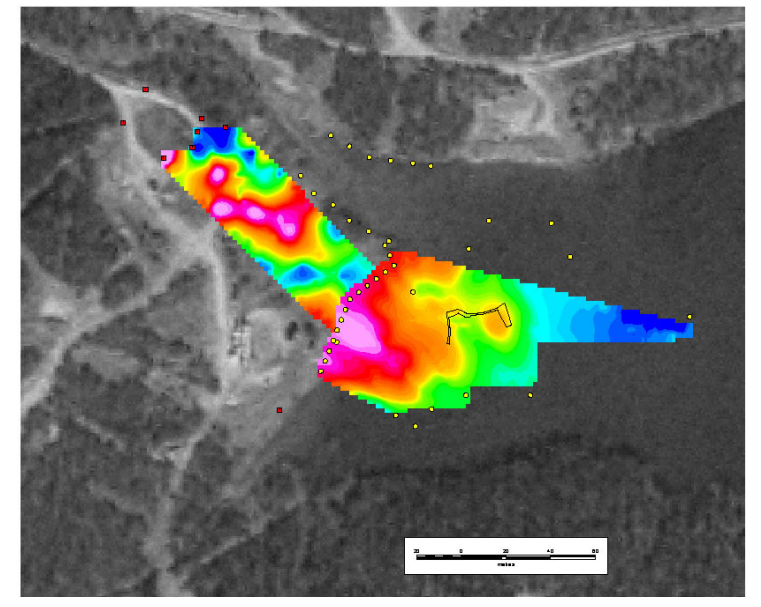

(a)

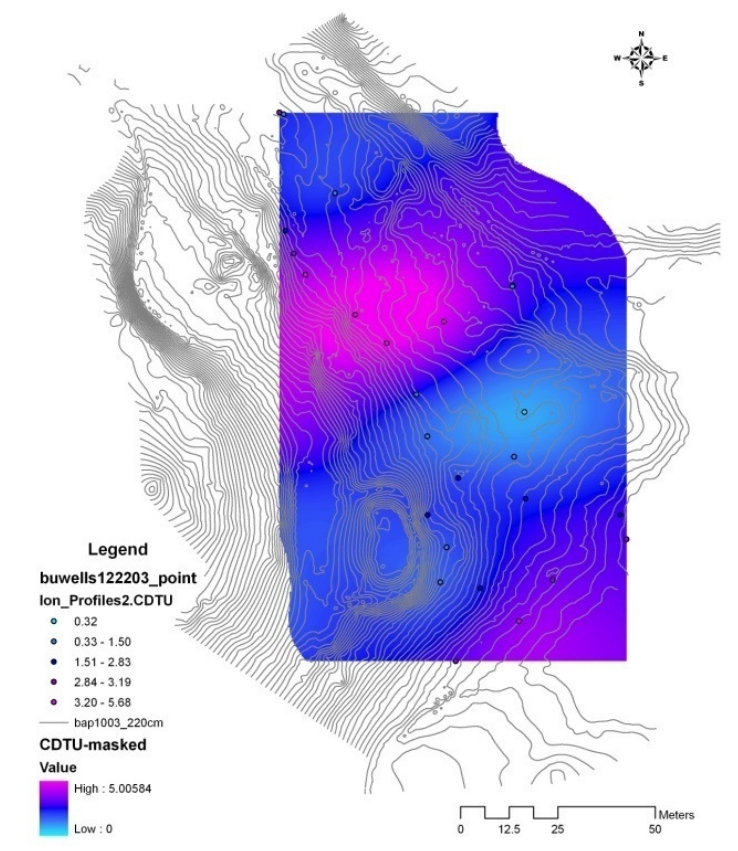

(c)

Figure 14. Surface conductivity at the oil production site observed using a GEM2 (see text), (a), courtesy of the USGS. Groundwater toxicity predicted from major ion profiles of groundwater well samples from May 2007 for the organisms Daphnia magna (b), Ceriodaphnia dubia (c), and fathead minnows (d) using the ion toxicity model and ordinary kriging. Warmer colors indicate increased conductivity or toxicity.

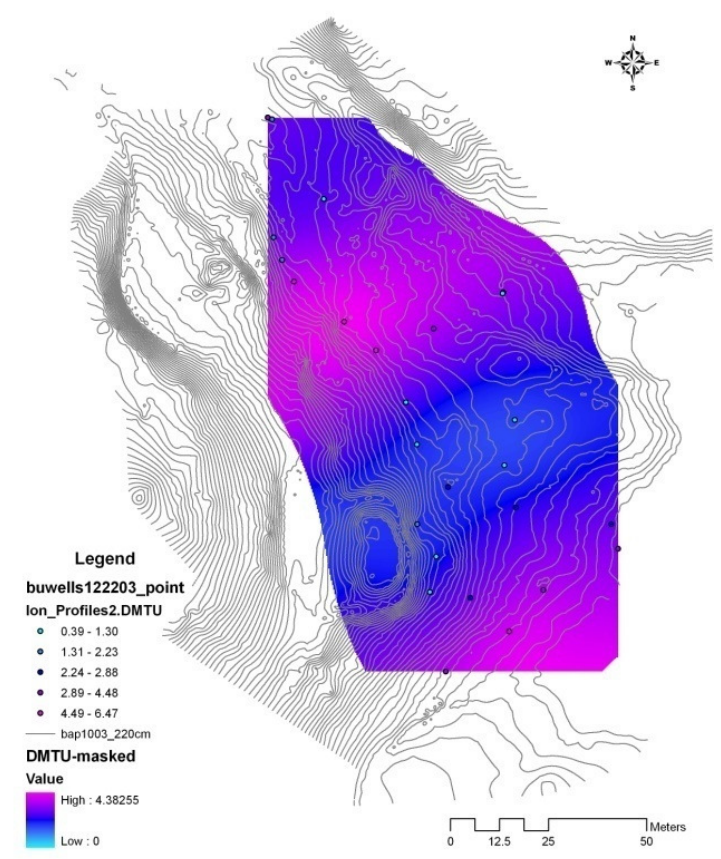

(b)

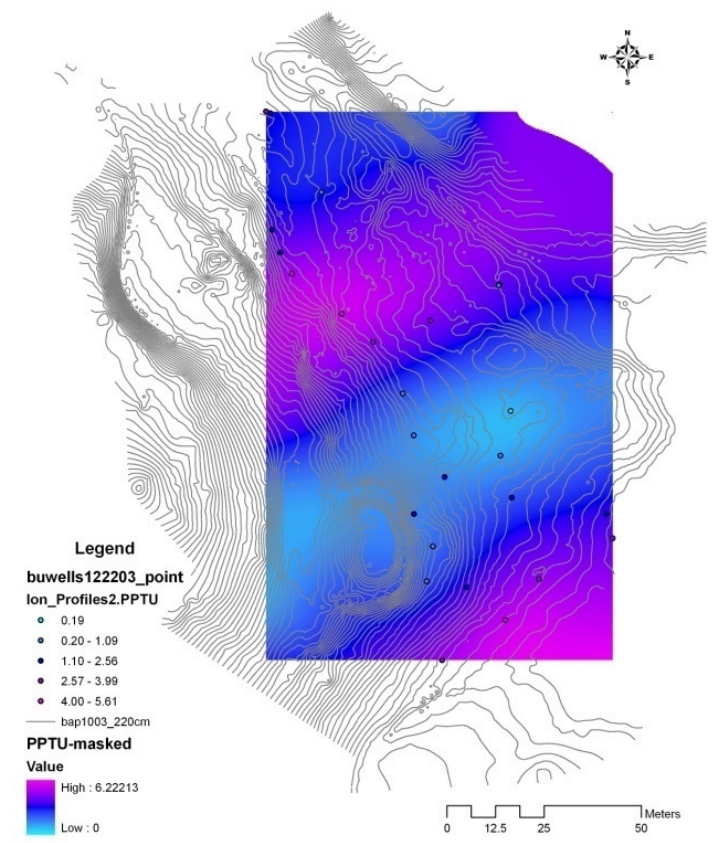




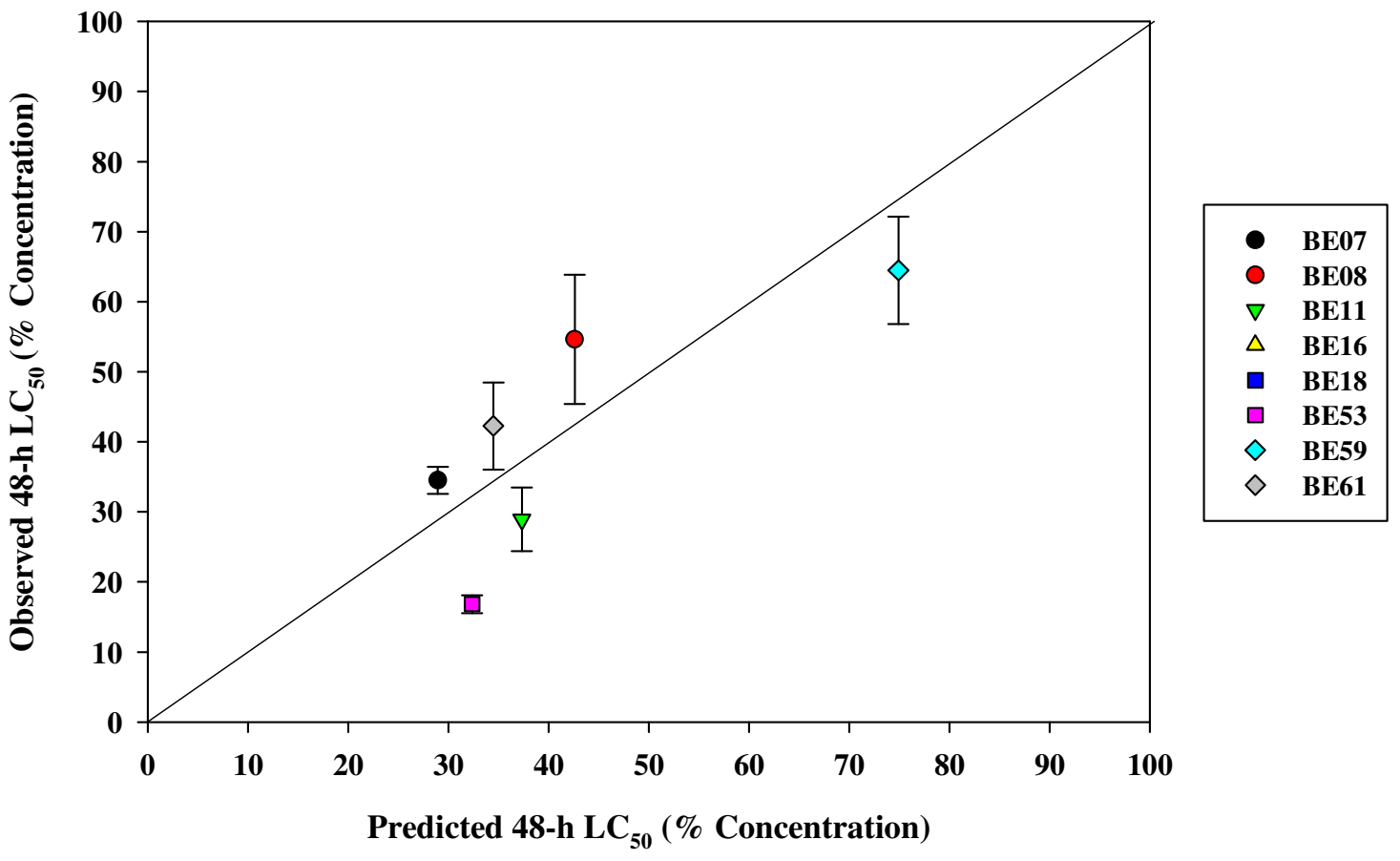

Figure 15. Comparison of $L_{5}$ 's measured from standardized toxicity tests (48-h Daphnia magna) on selected groundwater wells and LC50's derived from an ion toxicity model. Error bars are 95\% confidence intervals. The dotted line has a slope equal to one and represents agreement between actual and predicted values. 


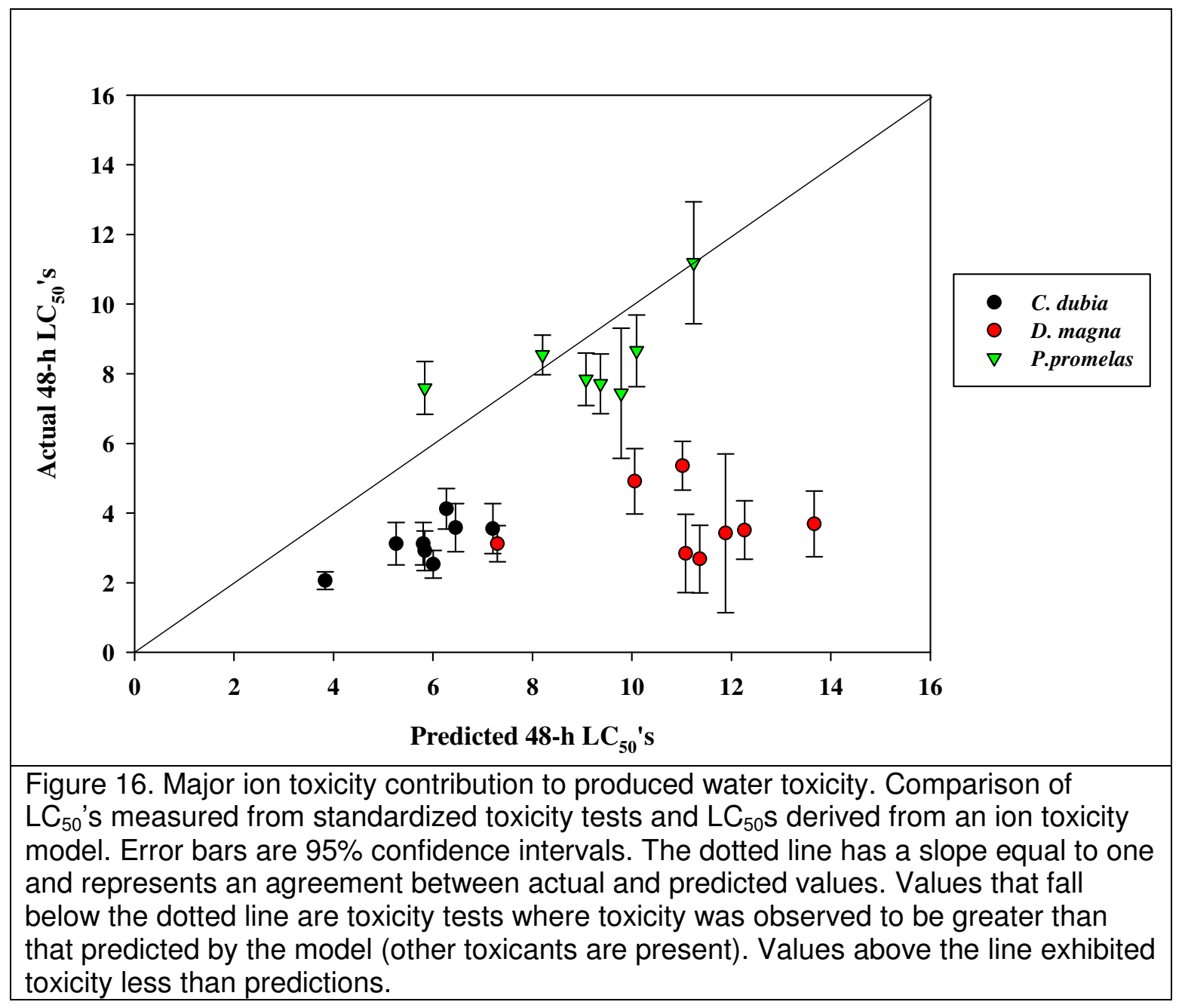




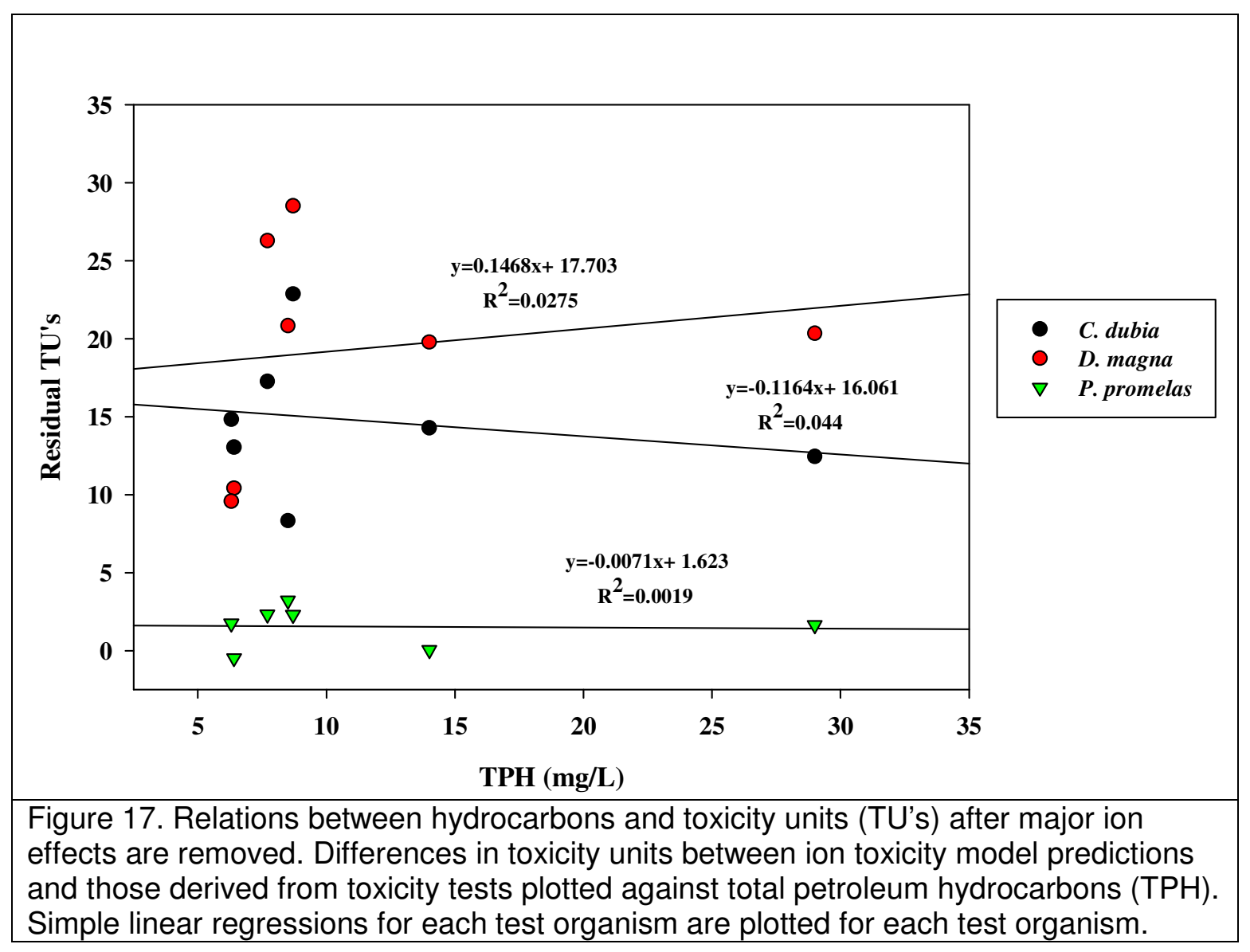




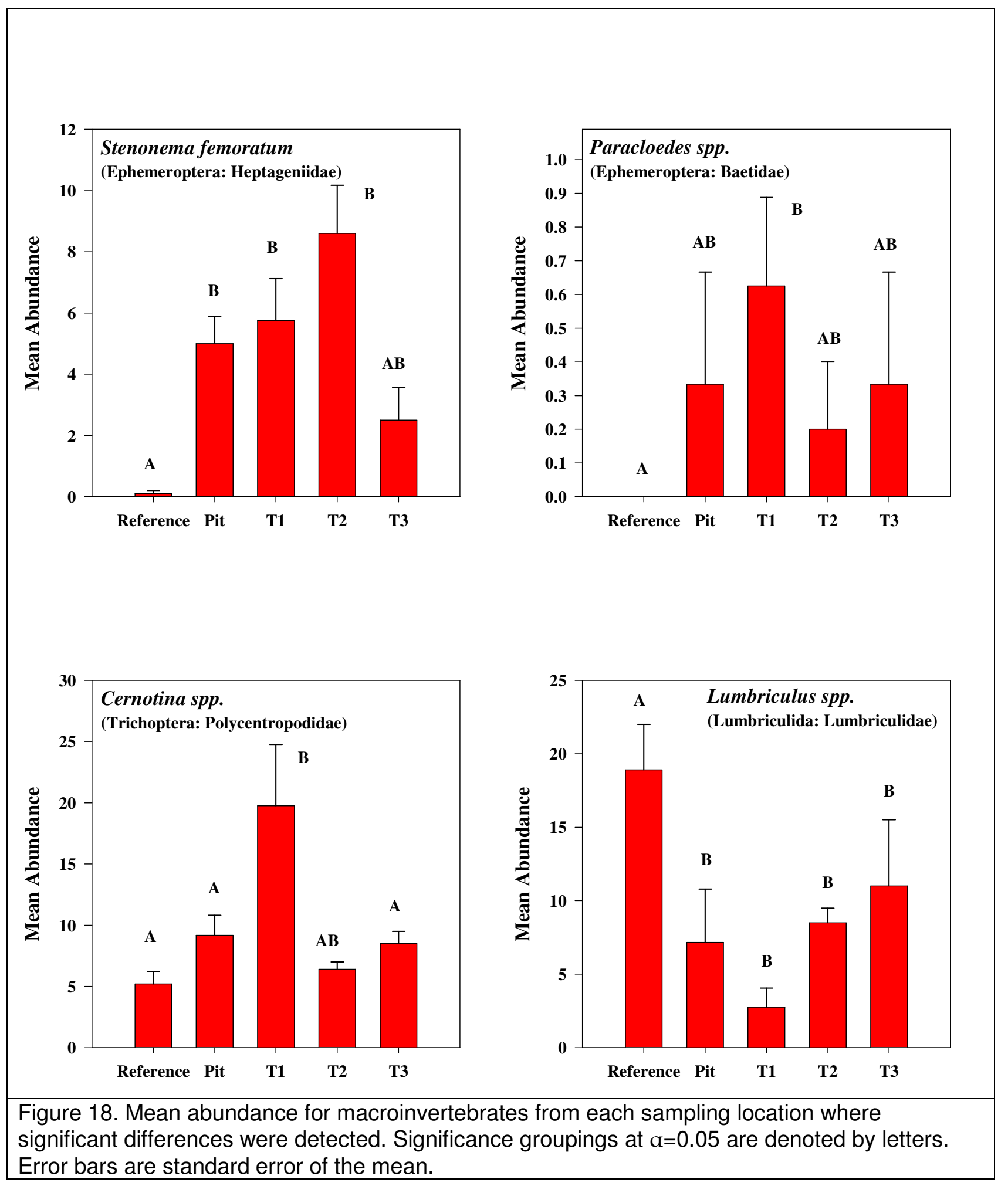



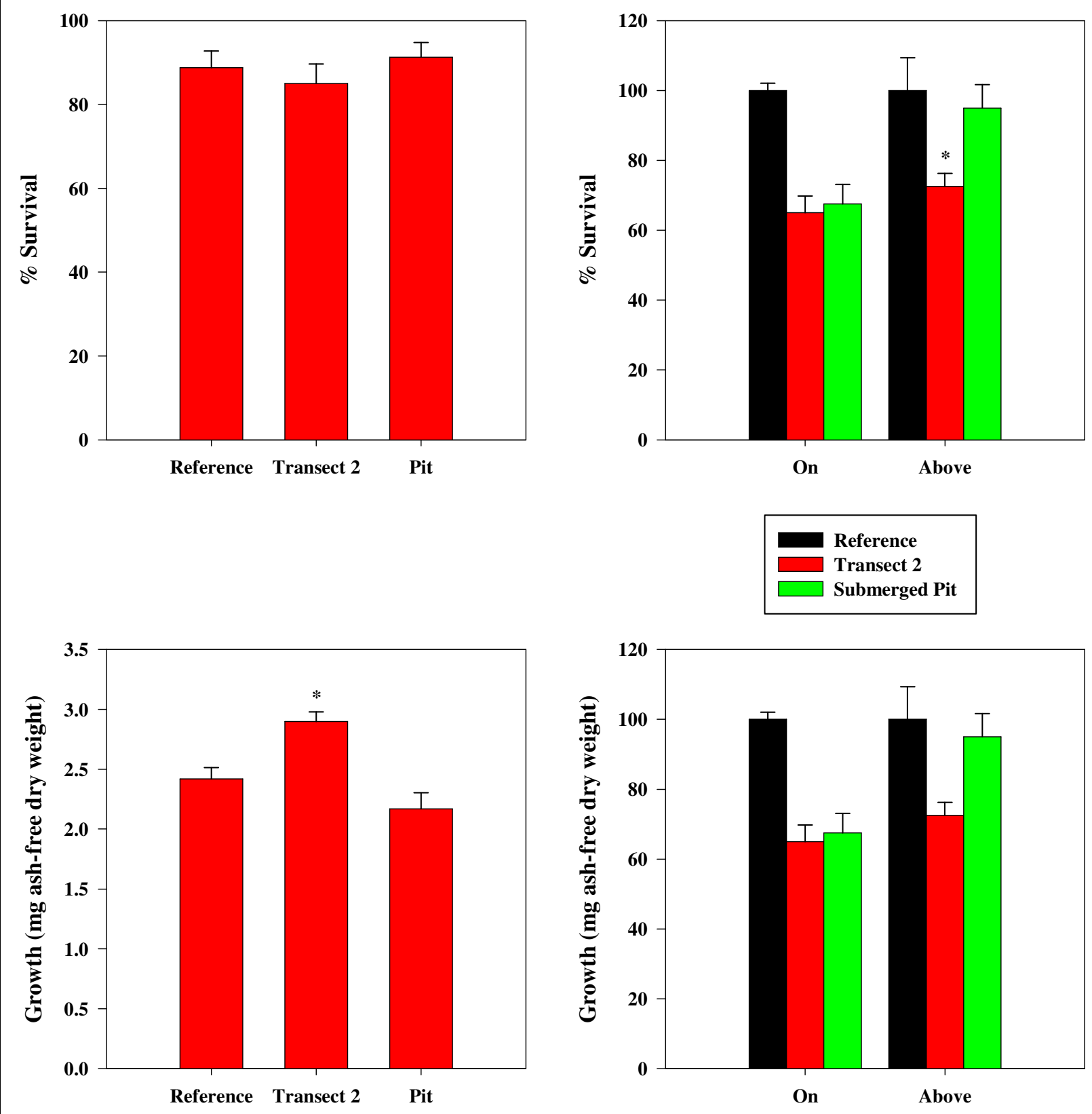

Figure 19. Mean survival (top row) and growth (bottom row) or midges in laboratory experiments (left column) and in situ chambers (right column) during the Fall of 2005. All means are based on a sample size of 4 replicated per location and treatment. Error bars are standard error of the mean and an asterisk $\left(^{*}\right)$ indicates a significant difference from reference site values at $a=0.05$. 


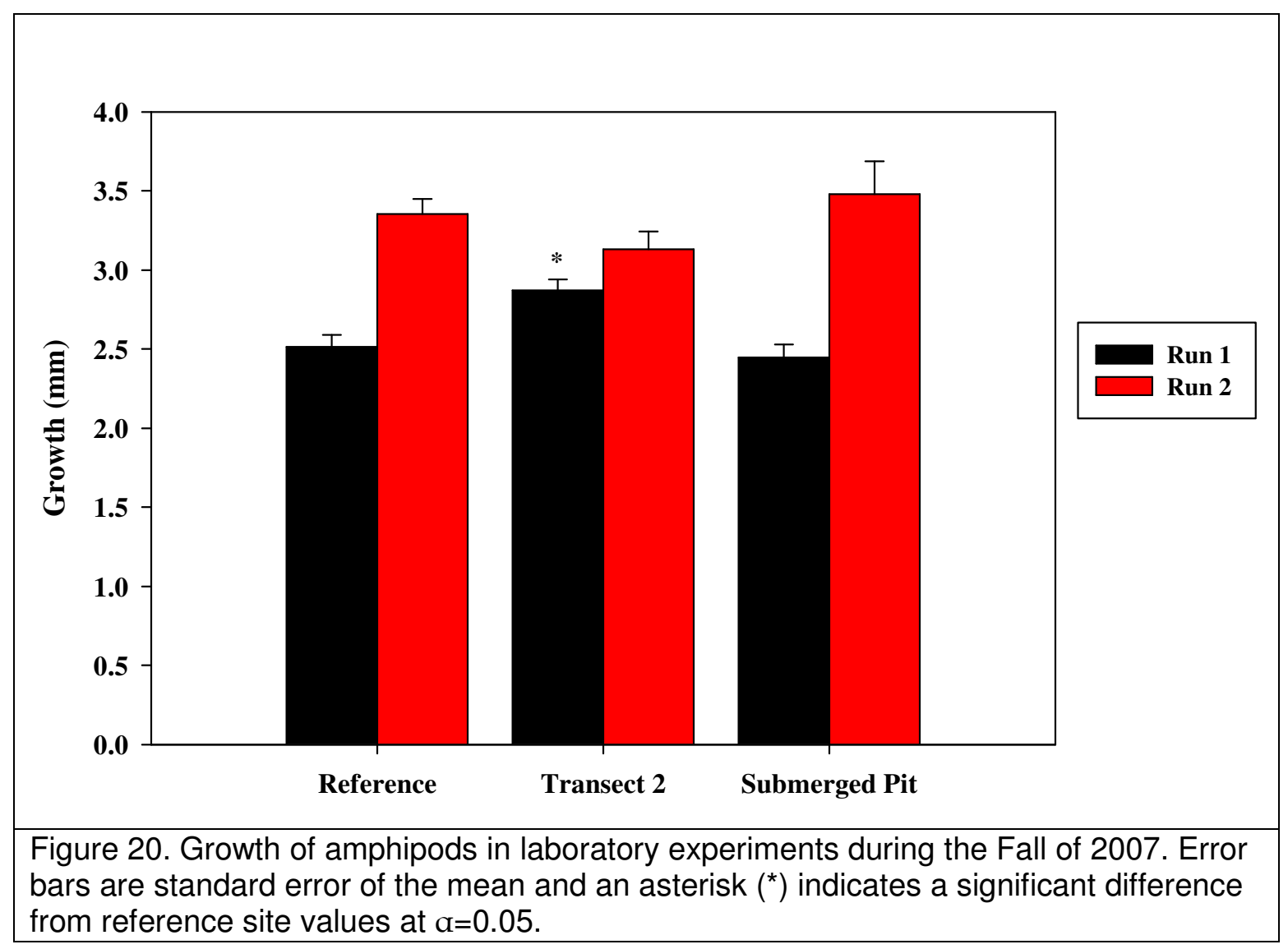




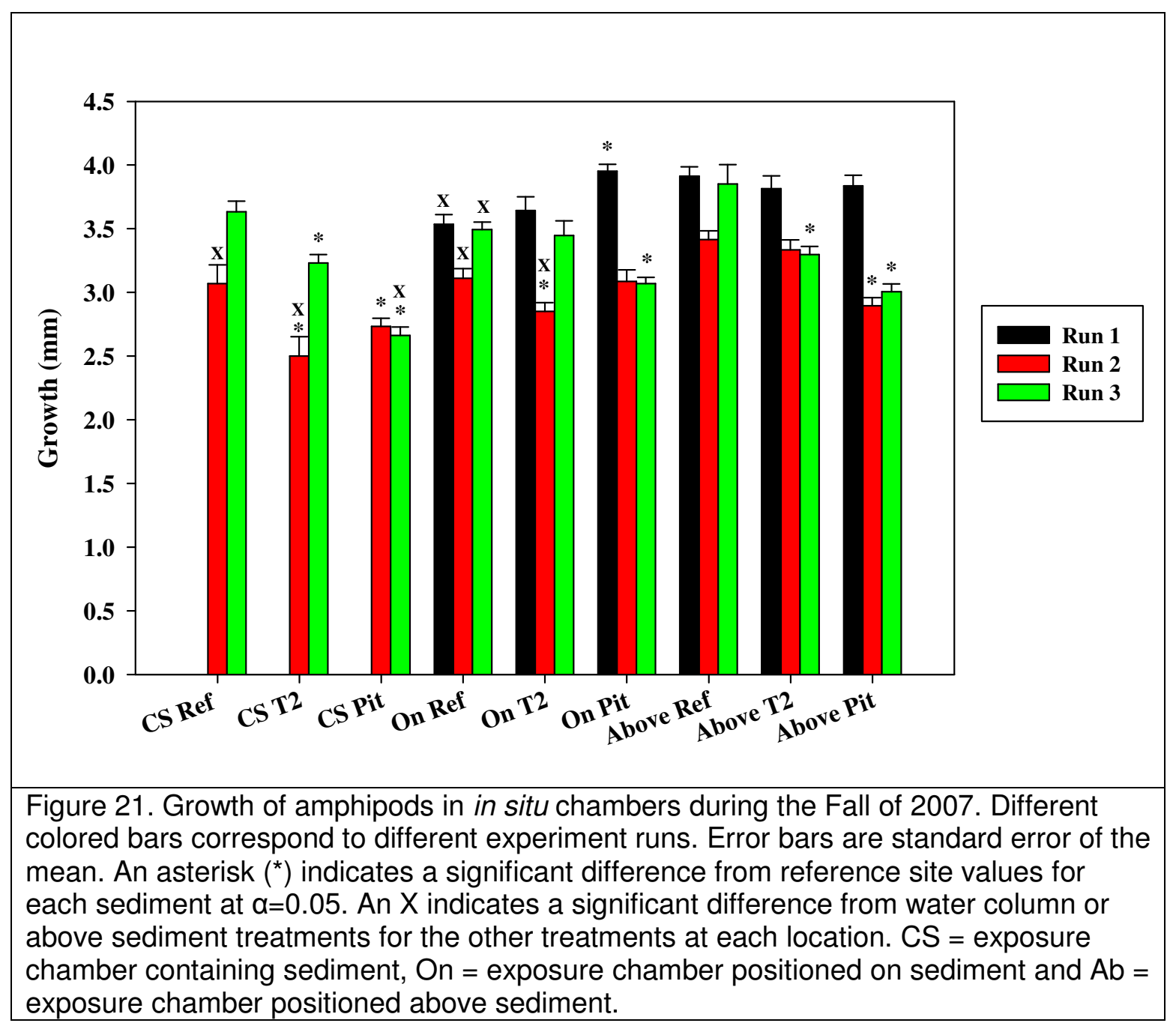


Table 1. Groundwater well water $\mathrm{pH}$. Dashes (-) indicate samples where too little volume was collected to be analyzed.

\begin{tabular}{|c|c|c|c|c|c|c|c|c|c|}
\hline \multirow[b]{2}{*}{ Well } & \multicolumn{3}{|c|}{2005} & \multicolumn{4}{|c|}{2006} & \multicolumn{2}{|c|}{2007} \\
\hline & Aug & Sep & Nov & Jan & Mar & May & Jul & Feb & May \\
\hline Lake & 8.32 & 7.92 & 8.01 & 8.04 & 7.93 & 7.95 & 7.96 & 7.30 & 7.60 \\
\hline 01 & 7.71 & 7.32 & 7.31 & 7.59 & 7.61 & 7.50 & 7.48 & 7.80 & 8.00 \\
\hline 03 & - & - & - & - & - & 6.73 & 6.67 & 5.90 & 6.70 \\
\hline 04 & - & - & - & - & 5.50 & - & - & 3.90 & 3.90 \\
\hline 05 & - & - & - & - & - & - & - & - & - \\
\hline 06 & 7.90 & 7.77 & 7.40 & 6.36 & 6.43 & 7.72 & 8.24 & 6.60 & 7.10 \\
\hline 07 & & 6.45 & 5.88 & 6.35 & 6.31 & 6.36 & 7.55 & 6.90 & 7.10 \\
\hline 08 & 7.41 & 7.23 & 7.41 & 7.04 & 6.88 & 7.69 & 7.64 & 7.10 & 7.40 \\
\hline 10 & 7.23 & 6.92 & 6.63 & 7.34 & 6.01 & 7.55 & 6.95 & 4.80 & 6.30 \\
\hline 11 & 6.98 & 6.86 & 7.48 & 7.12 & 6.78 & 7.10 & 7.15 & 6.90 & 7.30 \\
\hline 13 & 7.35 & - & 7.53 & 7.51 & 7.25 & 5.85 & 7.54 & 7.00 & 7.70 \\
\hline 15 & 7.20 & 7.41 & 7.16 & 7.44 & 6.51 & 7.42 & 7.95 & 6.50 & 7.20 \\
\hline 16 & 7.14 & 7.21 & 7.20 & 7.78 & 7.08 & 7.84 & 7.34 & 7.30 & 7.80 \\
\hline 17 & 7.55 & 7.39 & 7.54 & 7.60 & 7.49 & 7.48 & 7.41 & 7.60 & 8.00 \\
\hline 18 & 7.01 & 7.31 & 7.41 & 7.44 & 6.65 & 7.24 & 7.72 & 6.60 & 7.60 \\
\hline 19 & 6.95 & 7.34 & 7.54 & - & 6.26 & 8.02 & - & - & 7.30 \\
\hline 51 & 7.56 & 7.63 & 7.64 & - & - & 7.75 & 8.03 & 7.30 & 7.80 \\
\hline 52 & 6.97 & 6.97 & 7.07 & 7.45 & 6.88 & 6.88 & 6.85 & 7.30 & 7.60 \\
\hline 53 & 5.08 & 4.61 & 5.07 & 5.06 & 4.12 & 4.04 & 4.56 & 3.90 & 3.90 \\
\hline 54 & 6.08 & 6.28 & 5.73 & 5.83 & 5.80 & 6.03 & 6.49 & 6.10 & 6.90 \\
\hline 55 & 6.77 & 7.83 & 6.67 & 7.18 & 6.82 & 7.01 & 6.78 & 6.80 & 7.40 \\
\hline 56 & 6.86 & - & 6.88 & 7.38 & 6.22 & 7.02 & 7.08 & 6.90 & 7.30 \\
\hline 57 & 7.41 & 7,53 & 7.57 & 7.86 & 6.92 & 7.61 & 7.48 & 7.10 & 7.70 \\
\hline 58 & 7.48 & 7.71 & 7.67 & - & 7.81 & 7.49 & 7.65 & - & 6.80 \\
\hline 59 & 7.68 & 7.66 & 7.35 & 7.78 & 7.34 & 7.65 & 7.91 & 7.30 & 7.40 \\
\hline 60 & 7.46 & 6.67 & 7.54 & - & 6.22 & 7.07 & 6.98 & 5.70 & 6.50 \\
\hline 61 & 7.40 & 7.22 & 7.03 & 7.73 & 6.94 & 7.87 & 7.57 & 7.40 & 7.70 \\
\hline 62 & - & 6.66 & 6.59 & 6.84 & - & 7.16 & 6.57 & 7.50 & 7.50 \\
\hline
\end{tabular}


Table 2. Groundwater well water conductivity (uS/cm). Dashes (-) indicate samples where too little volume was collected to be analyzed.

\begin{tabular}{|c|c|c|c|c|c|c|c|c|c|}
\hline \multirow[b]{2}{*}{ Well } & \multicolumn{3}{|c|}{2005} & \multicolumn{4}{|c|}{2006} & \multicolumn{2}{|c|}{2007} \\
\hline & Aug & Sep & Nov & Jan & Mar & May & Jul & Feb & May \\
\hline Lake & 293 & 278 & 264 & 376 & 419 & 301 & 333 & 332 & 307 \\
\hline 01 & 8006 & 9527 & 7986 & 10560 & 10530 & 7861 & 9777 & 11110 & 10930 \\
\hline 03 & - & - & - & - & - & 10780 & 12910 & 7900 & 10990 \\
\hline 04 & - & - & - & - & 18220 & - & - & 38100 & 33500 \\
\hline 05 & - & - & - & - & - & - & - & - & - \\
\hline 06 & 5574 & 7472 & 5742 & 3923 & 2964 & 7638 & 7236 & 1374 & 1507 \\
\hline 07 & - & 14930 & 25170 & 28650 & 16080 & 17150 & 18340 & 15620 & 17750 \\
\hline 08 & 12670 & 14780 & 14880 & 17000 & 15810 & 12830 & 11080 & 18210 & 17590 \\
\hline 10 & 14150 & 22100 & 18410 & 16670 & 21260 & 12500 & 14910 & 17680 & 17350 \\
\hline 11 & 19430 & 21910 & 22940 & 22050 & 16490 & 14160 & 16570 & 21100 & 17900 \\
\hline 13 & 14620 & - & 15540 & 22670 & 15040 & 14240 & 14780 & 11950 & 13180 \\
\hline 15 & 9298 & 7965 & 9694 & 7631 & 5903 & 7263 & 10080 & 3980 & 5430 \\
\hline 16 & 11320 & 16390 & 14260 & 19760 & 13400 & 10230 & 11220 & 12830 & 16720 \\
\hline 17 & 11150 & 13630 & 10150 & 16280 & 12650 & 9958 & 11900 & 7020 & 11190 \\
\hline 18 & 17460 & 20650 & 22840 & 18190 & 13180 & 17100 & 16720 & 15650 & 20000 \\
\hline 19 & 8013 & 7555 & 8270 & - & 5563 & 4728 & - & - & 8900 \\
\hline 51 & 12570 & 13130 & 13390 & - & - & 8784 & 11930 & 5340 & 6580 \\
\hline 52 & 1599 & 16130 & 18490 & 14120 & 15780 & 11280 & 15650 & 20600 & 21000 \\
\hline 53 & 25260 & 34780 & 30990 & 20540 & 33150 & 23580 & 20590 & 24500 & 20300 \\
\hline 54 & 15030 & 17040 & 41310 & 24750 & 20350 & 13570 & 16810 & 12240 & 19100 \\
\hline 55 & 26820 & 22810 & 25760 & 23400 & 22830 & 15880 & 20740 & 31000 & 29700 \\
\hline 56 & 34380 & - & 36080 & 26520 & 21910 & 16280 & 23990 & 19760 & 23900 \\
\hline 57 & 15020 & 15260 & 15910 & 11730 & 8118 & 9506 & 14560 & 5430 & 7860 \\
\hline 58 & 11440 & 12170 & 10540 & - & 12560 & 9625 & 13040 & - & 6650 \\
\hline 59 & 11030 & 9041 & 7430 & 14490 & 6851 & 4831 & 9784 & 10430 & 5940 \\
\hline 60 & 11500 & 14010 & 11230 & - & 13530 & 9451 & 14080 & 13030 & 10420 \\
\hline 61 & 12950 & 17650 & 13500 & 20130 & 10990 & 9416 & 11550 & 12940 & 9670 \\
\hline 62 & - & 16830 & 13630 & 20860 & - & 11540 & 13810 & 17630 & 17200 \\
\hline
\end{tabular}


Table 3. Groundwater well water alkalinity $\left(\mathrm{mg} / \mathrm{L} \mathrm{CaCO}_{3}\right)$. Dashes (-) indicate samples where too little volume was collected to be analyzed.

\begin{tabular}{|c|c|c|c|c|c|c|c|c|c|}
\hline \multirow[b]{2}{*}{ Well } & \multicolumn{3}{|c|}{2005} & \multicolumn{4}{|c|}{2006} & \multicolumn{2}{|c|}{2007} \\
\hline & Aug & Sep & Nov & Jan & Mar & May & Jul & Feb & May \\
\hline Lake & 76 & 70 & 100 & 78 & 76 & 76 & 74 & 62 & 59 \\
\hline 01 & 640 & 752 & 790 & 744 & 620 & 750 & 784 & 769 & 659 \\
\hline 03 & - & - & - & - & - & 36 & 56 & 14 & 27 \\
\hline 04 & - & - & - & - & 24 & - & - & 0 & 0 \\
\hline 05 & - & - & - & - & - & - & - & - & - \\
\hline 06 & 273 & 226 & 210 & 42 & 58 & 252 & - & 18 & 31 \\
\hline 07 & & 166 & 178 & 152 & 122 & 224 & 428 & 117 & 160 \\
\hline 08 & 596 & 826 & 702 & 532 & 260 & 764 & 822 & 44 & 149 \\
\hline 10 & 424 & 152 & 96 & 128 & 56 & 88 & 222 & 0 & 18 \\
\hline 11 & 210 & 202 & 200 & 100 & 84 & 154 & 124 & 101 & 103 \\
\hline 13 & 558 & & 574 & 830 & 898 & 34 & 760 & 179 & 423 \\
\hline 15 & 382 & 278 & 302 & 166 & 140 & 264 & 446 & 31 & 89 \\
\hline 16 & 440 & 636 & 760 & 838 & 660 & 670 & 460 & 143 & 688 \\
\hline 17 & 862 & 876 & 944 & 992 & 960 & 954 & 912 & 294 & 590 \\
\hline 18 & 544 & 692 & 540 & 570 & 316 & 630 & 644 & 98 & 463 \\
\hline 19 & 290 & 148 & 170 & - & 36 & 232 & - & - & 100 \\
\hline 51 & 960 & 912 & 670 & - & - & 764 & 622 & 169 & 192 \\
\hline 52 & 480 & 542 & 524 & 498 & 334 & 260 & 428 & 295 & 309 \\
\hline 53 & 8 & 4 & 0 & 2 & 0 & 0 & 0 & 0 & 0 \\
\hline 54 & 60 & 82 & 60 & 54 & 58 & 62 & 40 & 28 & 55 \\
\hline 55 & 564 & 440 & 314 & 566 & 194 & 334 & 458 & 176 & 174 \\
\hline 56 & 480 & - & 392 & 412 & 84 & 222 & 362 & 97 & 102 \\
\hline 57 & 550 & 508 & 472 & 282 & 160 & 326 & 482 & 67 & 122 \\
\hline 58 & 592 & 568 & 378 & - & 416 & 434 & 604 & - & 17 \\
\hline 59 & 334 & - & - & 328 & - & 158 & 330 & 98 & 75 \\
\hline 60 & 506 & 276 & 94 & - & 38 & 144 & 150 & 9 & 20 \\
\hline 61 & 54 & 1178 & 1092 & 1060 & 692 & 780 & 1076 & 502 & 278 \\
\hline 62 & - & 414 & 570 & 524 & - & 482 & 428 & 493 & 389 \\
\hline
\end{tabular}


Table 4. Groundwater well water hardness (mg/L $\left.\mathrm{CaCO}_{3}\right)$. Dashes (-) indicate samples where too little volume was collected to be analyzed.

\begin{tabular}{|c|c|c|c|c|c|c|c|c|c|}
\hline \multirow[b]{2}{*}{ Well } & \multicolumn{3}{|c|}{2005} & \multicolumn{4}{|c|}{2006} & \multicolumn{2}{|c|}{2007} \\
\hline & Aug & Sep & Nov & Jan & Mar & May & Jul & Feb & May \\
\hline Lake & 84 & 86 & 86 & 90 & 90 & 94 & 96 & 93 & 79 \\
\hline 01 & 4380 & 5480 & 5520 & 5520 & 5020 & 5860 & 5720 & 6144 & 5754 \\
\hline 03 & - & - & - & - & - & 2860 & 2660 & 981 & 1574 \\
\hline 04 & - & - & - & - & 3400 & - & - & 5827 & 4984 \\
\hline 05 & - & - & - & - & - & - & - & - & - \\
\hline 06 & 2700 & 2000 & 7440 & 780 & 500 & 3300 & 2600 & 185 & 225 \\
\hline 07 & - & 3400 & 5280 & 4700 & 3240 & 4620 & 8900 & 2521 & 2961 \\
\hline 08 & 4840 & 7480 & 8220 & 6980 & 5100 & 6620 & 7540 & 2713 & 3251 \\
\hline 10 & 8180 & 5740 & 5400 & 5020 & 5520 & 4260 & 5560 & 3061 & 3202 \\
\hline 11 & 3760 & 4560 & 5680 & 3600 & 2640 & 2800 & 4280 & 3571 & 2412 \\
\hline 13 & 6960 & - & 6480 & 8160 & 7820 & 2120 & 7060 & 2703 & 4403 \\
\hline 15 & 4220 & 2900 & 3400 & 1760 & 1120 & 2620 & 4500 & 613 & 1008 \\
\hline 16 & 3090 & 8100 & 8600 & 8220 & 7720 & 7060 & 8460 & 4631 & 8142 \\
\hline 17 & 8360 & 7960 & 7160 & 7660 & 7220 & 6840 & 6860 & 2775 & 5529 \\
\hline 18 & 3520 & 9260 & 9420 & 9620 & 4400 & 7880 & 11060 & 3194 & 7151 \\
\hline 19 & 1240 & 1380 & 1600 & - & 680 & 1160 & - & - & 1215 \\
\hline 51 & 8440 & 7980 & 9260 & - & - & 6080 & 6120 & 169 & 2365 \\
\hline 52 & 6600 & 8580 & 9960 & 7760 & 6680 & 3860 & 8340 & 7451 & 7466 \\
\hline 53 & 20000 & 8000 & 9040 & 8760 & 10800 & 7700 & 9780 & 3853 & 2882 \\
\hline 54 & 2720 & 2120 & 9560 & 6460 & 3320 & 3280 & 3500 & 1520 & 2393 \\
\hline 55 & 12000 & 8600 & 9700 & 12920 & 7040 & 8060 & 11160 & 6646 & 6343 \\
\hline 56 & 10260 & - & 40000 & 11180 & 2380 & 6700 & 12220 & 2321 & 3292 \\
\hline 57 & 4560 & 5060 & 6340 & 3300 & 1860 & 3000 & 5780 & 671 & 1161 \\
\hline 58 & 3840 & 6560 & 5080 & - & 5100 & 5180 & 7960 & - & 1363 \\
\hline 59 & 2890 & - & - & 3580 & - & 1000 & 3200 & 1989 & 818 \\
\hline 60 & 4920 & 3300 & 2340 & - & 2060 & 4060 & 3080 & 1627 & 1088 \\
\hline 61 & 5110 & 8140 & 8740 & 8380 & 5060 & 5600 & 8160 & 5432 & 3053 \\
\hline 62 & - & 4600 & 6060 & 5040 & - & 4720 & 4940 & 5101 & 4423 \\
\hline
\end{tabular}


Table 5. Conductivity and $\mathrm{pH}$ of pore water samples taken.

\begin{tabular}{|c|c|c|c|c|c|c|}
\hline & \multirow{2}{*}{$\begin{array}{l}\text { Mean } \\
\text { Depth } \\
\text { (cm) }\end{array}$} & \multicolumn{5}{|c|}{ Location } \\
\hline & & Reference & $\begin{array}{c}\text { Transect } \\
1 \\
\end{array}$ & $\begin{array}{c}\text { Transect } \\
2 \\
\end{array}$ & $\begin{array}{c}\text { Transect } \\
3 \\
\end{array}$ & Pit \\
\hline Conductivity & 2.5 & 331 & 604 & 795 & 837 & 2110 \\
\hline \multirow[t]{5}{*}{$(\mu \mathrm{S} / \mathrm{cm})$} & 7.5 & 390 & 1031 & 608 & 5206 & 7194 \\
\hline & 12.5 & 238 & 2224 & 1479 & 8979 & 9784 \\
\hline & 17.5 & 158 & 3414 & 3352 & 10200 & 6965 \\
\hline & 22.5 & 137 & 4143 & 3206 & 2170 & 9847 \\
\hline & 27.5 & 137 & 4409 & 2445 & 12090 & 8062 \\
\hline \multirow[t]{6}{*}{$\mathrm{pH}$} & 2.5 & 6.94 & 7.83 & 7.61 & 7.14 & 7.70 \\
\hline & 7.5 & 7.87 & 7.58 & 7.59 & 4.99 & 7.85 \\
\hline & 12.5 & 7.67 & 7.07 & 7.68 & 4.00 & 8.00 \\
\hline & 17.5 & 7.68 & 4.47 & 7.95 & 4.01 & 7.98 \\
\hline & 22.5 & 7.67 & 3.84 & 8.03 & 6.60 & 8.03 \\
\hline & 27.5 & 7.57 & 3.80 & 8.17 & 7.32 & 8.16 \\
\hline
\end{tabular}


Table 6. Ion concentrations of pore water samples for each sampling location. Empty cells represent samples of too little volume or ion concentration to be quantified.

\begin{tabular}{|c|c|c|c|c|c|c|c|c|c|}
\hline Location & $\begin{array}{c}\text { Mean } \\
\text { Depth } \\
\text { cm }\end{array}$ & $\begin{array}{c}\mathrm{Na} \\
\mathrm{mg} / \mathrm{L}\end{array}$ & $\begin{array}{c}\mathrm{Ca} \\
\mathrm{mg} / \mathrm{L}\end{array}$ & $\begin{array}{c}\mathrm{Mg} \\
\mathrm{mg} / \mathrm{L}\end{array}$ & $\begin{array}{c}\mathrm{K} \\
\mathrm{mg} / \mathrm{L}\end{array}$ & $\begin{array}{c}\mathrm{Cl} \\
\mathrm{mg} / \mathrm{L}\end{array}$ & $\begin{array}{c}\mathrm{SO}_{4} \\
\mathrm{mg} / \mathrm{L}\end{array}$ & $\begin{array}{c}\mathrm{NO}_{3} \\
\mathrm{mg} / \mathrm{L}\end{array}$ & $\begin{array}{c}\text { Boron } \\
\mathrm{mg} / \mathrm{L}\end{array}$ \\
\hline \multirow[t]{6}{*}{ Reference } & 2.5 & & & & & 0.4 & & 0.27 & \\
\hline & 7.5 & & & & & 0.0 & & 0.27 & \\
\hline & 12.5 & 16.3 & 22.5 & 9.6 & 4 & 0.0 & 29.6 & 0.27 & 0.01 \\
\hline & 17.5 & 19.1 & 10.4 & 4.7 & 2 & 0.0 & 30.7 & 0.26 & 0.01 \\
\hline & 22.5 & 19.8 & 7.6 & 3.6 & 1.7 & 0.0 & 28.3 & 0.27 & 0.01 \\
\hline & 27.5 & 19.1 & 7.7 & 3.9 & 1.6 & 0.0 & 21.4 & 0.26 & 0.01 \\
\hline \multirow[t]{6}{*}{ Transect 1} & 2.5 & 63.5 & 39.1 & 10.8 & 7.9 & 100.7 & 44.2 & 0.25 & 0.03 \\
\hline & 7.5 & 163.7 & 48.2 & 18.4 & 6.4 & 269.7 & 156.6 & 0.37 & 0.08 \\
\hline & 12.5 & 413.8 & 117.7 & 41.8 & 7.8 & 712.8 & 321.4 & 0.44 & 0.16 \\
\hline & 17.5 & 674.5 & 173.3 & 60.5 & 9.4 & 1199.1 & 358.6 & 0.44 & 0.19 \\
\hline & 22.5 & 872.6 & 195.4 & 88.9 & 9.4 & 1661.7 & 409.3 & 0.45 & 0.28 \\
\hline & 27.5 & 825.5 & 172.2 & 84.5 & 7.9 & 1484.8 & 407.3 & 0.65 & 0.21 \\
\hline \multirow[t]{6}{*}{ Transect 2} & 2.5 & 128.8 & 57.7 & 15.6 & 6.4 & 257.4 & 46.4 & 0.44 & 0.04 \\
\hline & 7.5 & & & & & 216.7 & & 0.46 & \\
\hline & 12.5 & 267.1 & 95.9 & 22.4 & 6.8 & 480.9 & 117.4 & 0.46 & 0.08 \\
\hline & 17.5 & 581 & 217 & 49.5 & 10.2 & 1373.4 & 183.2 & 0.64 & 0.15 \\
\hline & 22.5 & 571.6 & 139.4 & 34 & 6.7 & 1025.2 & 91.0 & 0.45 & 0.16 \\
\hline & 27.5 & 539.2 & 87.9 & 22.7 & 6.7 & 798.3 & 45.8 & 0.29 & 0.15 \\
\hline \multirow[t]{6}{*}{ Transect 3} & 2.5 & 134.7 & 32.2 & 9.2 & 5.1 & 241.0 & 19.9 & 0.39 & 0.04 \\
\hline & 7.5 & 1290.7 & 148.9 & 47.3 & 11.6 & 2471.9 & 12.9 & 0.56 & 0.16 \\
\hline & 12.5 & 2378.7 & 322 & 113.5 & 16.3 & 4495.2 & 17.6 & 0.00 & 0.32 \\
\hline & 17.5 & 2881.3 & 374.3 & 130.4 & 17.6 & 5172.1 & 16.4 & 0.64 & 0.36 \\
\hline & 22.5 & 3870.8 & 433.7 & 146.3 & 26.3 & 11763.3 & 21.5 & 0.00 & 0.41 \\
\hline & 27.5 & 3569.4 & 358 & 118.7 & 25.3 & 5828.7 & 19.9 & 0.59 & 0.42 \\
\hline \multirow[t]{6}{*}{ Pit } & 2.5 & 424.8 & 59.2 & 18.8 & 5.7 & 712.6 & 30.6 & 0.51 & 0.08 \\
\hline & 7.5 & 1888 & 233.1 & 74 & 12.3 & 3469.3 & 33.7 & 0.34 & 0.31 \\
\hline & 12.5 & 2465.5 & 277.5 & 94 & 17.1 & 4469.1 & 27.3 & 1.53 & 0.39 \\
\hline & 17.5 & 1884.7 & 192.9 & 65.7 & 12.9 & 3329.0 & 15.7 & 0.89 & 0.29 \\
\hline & 22.5 & 2928.7 & 325.9 & 115.8 & 18.7 & 4985.1 & 19.0 & 1.27 & 0.31 \\
\hline & 27.5 & 2309.5 & 223.2 & 77.3 & 17.5 & 3819.1 & 16.0 & 0.92 & 0.50 \\
\hline
\end{tabular}


Table 7. Estimates (worst-case)/best case of potential major ion toxicity to Daphnia magna using pore water ion profiles. Presented values are toxicity units (100\% mixture divided by \% predicted $48 \mathrm{LC}_{50}$ ). Bolded values indicate samples where toxicity is predicted below $100 \%$ concentration.

\begin{tabular}{cccccc} 
& \multicolumn{5}{c}{ Location } \\
\cline { 2 - 6 } $\begin{array}{c}\text { Mean Depth } \\
(\mathbf{c m})\end{array}$ & Reference & Transect & Transect & Transect & Pit \\
\hline $\mathbf{2 . 5}$ & $0.18 / 0.81$ & $0.21 / 0.85$ & $0.24 / 0.88$ & $0.23 / 0.87$ & $0.32 / 0.96$ \\
$\mathbf{7 . 5}$ & $0.18 / 0.81$ & $0.24 / 0.88$ & $0.21 / 0.85$ & $0.66 / \mathbf{1 . 3 0}$ & $0.86 / \mathbf{1 . 5 0}$ \\
$\mathbf{1 2 . 5}$ & $0.19 / 0.83$ & $0.34 / 0.98$ & $0.28 / 0.92$ & $\mathbf{1 . 0 8 / 1 . 7 2}$ & $\mathbf{1 . 0 6 / 1 . 7 0}$ \\
$\mathbf{1 7 . 5}$ & $0.18 / 0.82$ & $0.44 / \mathbf{1 . 0 8}$ & $0.47 / \mathbf{1 . 1 1}$ & $\mathbf{1 . 2 2 / 1 . 8 6}$ & $0.83 / \mathbf{1 . 4 7}$ \\
$\mathbf{2 2 . 5}$ & $0.18 / 0.82$ & $0.55 / \mathbf{1 . 1 9}$ & $0.39 / \mathbf{1 . 0 3}$ & $\mathbf{2 . 4 0 / 3 . 0 4}$ & $\mathbf{1 . 1 7 / 1 . 8 1}$ \\
$\mathbf{2 7 . 5}$ & $0.18 / 0.82$ & $0.51 / \mathbf{1 . 1 5}$ & $0.34 / 0.98$ & $\mathbf{1 . 3 3 / 1 . 9 7}$ & $\mathbf{0 . 9 3 / 1 . 5 7}$ \\
\hline
\end{tabular}


Table 8. Effects of TIE manipulations on produced water toxicity to D. pulex. Values are $48-h C_{50}$ 's for each manipulation. Significant differences $(\alpha=0.05)$ from baseline toxicity are indicated in bold.

$\%$ LC $_{50}$ (\% produced water), $(95 \% \mathrm{Cl})$

\begin{tabular}{lccc} 
& & & \\
\cline { 2 - 4 } TIE Manipulation & February 2006 & March 2007 & September 2007 \\
\hline & 2.73 & 0.66 & 1.99 \\
Baseline & $(1.17,7.48)$ & $(0.0099,13.62)$ & $(1.92,2.05)$ \\
pH 6 & NA & 0.95 & NA \\
pH 7 & 2.93 & 0.51 & 2.01 \\
pH 8 & 3.39 & 0.78 & 1.95 \\
EDTA & $\mathbf{3 . 7 6}$ & 0.82 & $\mathbf{2 . 9 9}$ \\
Oxidant Reduction & 3.41 & 1.38 & $\mathbf{2 . 9 9}$ \\
pH 3 & 2.07 & NA & 2.25 \\
pH 11 & 2.90 & 0.51 & 1.98 \\
Filtration & 3.51 & 0.76 & $\mathbf{1 . 5 0}$ \\
pH 3 filtration & 1.56 & NA & $\mathbf{1 . 5 0}$ \\
pH 11 filtration & 3.77 & 1.34 & 1.95 \\
Aeration & 2.56 & 0.66 & 2.05 \\
pH 3 aeration & 2.81 & NA & 2.01 \\
pH 11 aeration & 4.07 & 0.52 & $\mathbf{2 . 9 9}$ \\
SPE & 2.35 & 0.66 & 2.05 \\
pH 3 SPE & 2.07 & NA & $\mathbf{1 . 5 0}$ \\
pH 9 SPE & 3.22 & 2.99 & $\mathbf{2 . 9 9}$ \\
\hline
\end{tabular}


Table 9. Summary of macroinvertebrate samples. Taxa richness is the total number of taxa per sample. Diversity is Shannon-Wiener diversity of each sample.

\begin{tabular}{clcccc} 
Location & Season & N & $\begin{array}{c}\text { Mean number } \\
\text { of Taxa }\end{array}$ & $\begin{array}{c}\text { Mean Taxa } \\
\text { Richness }\end{array}$ & $\begin{array}{c}\text { Diversity } \\
\text { (H') }\end{array}$ \\
\hline Reference & Spring & 10 & 55.7 & 6.9 & 1.24 \\
Transect 1 & Spring & 5 & 57.2 & 9.2 & 1.43 \\
& Fall & 3 & 187.0 & 9.0 & 1.41 \\
Transect 2 & Spring & 5 & 59.0 & 10.0 & 1.55 \\
Transect 3 & Spring & 3 & 77.7 & 10.7 & 1.34 \\
& Fall & 3 & 131.3 & 9.3 & 1.62 \\
\multicolumn{1}{c}{ Pit } & Spring & 3 & 72.0 & & 1.05 \\
& Fall & 3 & 68.0 & 8.0 & 1.82 \\
\hline
\end{tabular}

Table 10. Growth rates ( $\mathrm{mm} / 30$ days) of Asian clams from in situ growth experiments. Rates are corrected for length of experiment (30 to 35 days) and initial size.

\begin{tabular}{ccccc} 
Year & $\begin{array}{c}\text { Year } \\
\text { Mean }\end{array}$ & Reference & $\begin{array}{c}\text { Transect } \\
\mathbf{2}\end{array}$ & $\begin{array}{c}\text { Submerged Brine } \\
\text { Pit }\end{array}$ \\
\hline $\mathbf{2 0 0 5}$ & 1.01 & 1.54 & 1.10 & 1.16 \\
$\mathbf{2 0 0 6}$ & 0.81 & 0.65 & - & 0.26 \\
$\mathbf{2 0 0 7}$ & 1.14 & 0.89 & 0.77 & 0.84 \\
Total & & 1.05 & 0.86 & 0.79 \\
\hline
\end{tabular}


Appendix I: Aquatic Macroinvertebrate Taxa Data 
Appendix Table 1a. Macroinvertebrates identified from the reference site in 10 replicates in Spring 2006.

\begin{tabular}{|c|c|c|c|c|c|c|c|c|c|c|}
\hline \multirow[b]{2}{*}{ Spring 2006} & \multicolumn{10}{|c|}{$\begin{array}{c}\text { Reference Site } \\
\text { Replicates }\end{array}$} \\
\hline & 1 & 2 & 3 & 4 & 5 & 6 & 7 & 8 & 9 & 10 \\
\hline \multicolumn{11}{|l|}{ Ephemeroptera } \\
\hline Caenis & & & & & & 2 & 1 & & 2 & \\
\hline Stenonema & & & & & 1 & & & & & \\
\hline Odonata & & & & & & & & & & \\
\hline $\begin{array}{l}\text { Coenagrionidae } \\
\text { Megaloptera }\end{array}$ & & & & & & & & 1 & & \\
\hline $\begin{array}{l}\text { Sialis } \\
\text { Trichoptera }\end{array}$ & & 1 & & & & & & & & 1 \\
\hline Cernotina & & 4 & & 8 & 6 & 6 & 6 & 5 & 10 & 7 \\
\hline Cyrnellus & & & & 1 & & 1 & & & 3 & 4 \\
\hline Oecetis & & & & & & & & & & 1 \\
\hline Orthotrichia & & & & & & & 1 & & & \\
\hline $\begin{array}{l}\text { Diptera } \\
\text { Probezzia }\end{array}$ & & & & & & & & & & 1 \\
\hline $\begin{array}{l}\text { Chironomidae } \\
\text { Amphipoda }\end{array}$ & 18 & 20 & 8 & 20 & 33 & 20 & 45 & 29 & 18 & 39 \\
\hline Hyallela & & & 1 & 1 & 2 & & & 2 & & 2 \\
\hline $\begin{array}{l}\text { Branchiura } \\
\text { Annelida }\end{array}$ & & & 1 & 1 & & & & 1 & & \\
\hline Lumbriculus & 27 & 12 & 36 & 33 & 19 & 11 & 18 & 12 & 13 & 8 \\
\hline Amphichaeta & 2 & & & & & & & & & \\
\hline Nais & & & & & & & & & 3 & 1 \\
\hline $\begin{array}{l}\text { Gordiodea } \\
\text { Pelecypoda }\end{array}$ & & 1 & & 2 & & & & & & \\
\hline Corbicula & & & & & & & 1 & & 1 & \\
\hline Unionidae & & & & & & & & & 1 & 1 \\
\hline Hydrachnida & & & & & 1 & & & & 1 & 1 \\
\hline
\end{tabular}


Appendix Table 1b. Macroinvertebrates identified from Transect 1 and 2 in 5 replicates in Spring 2006.

\begin{tabular}{|c|c|c|c|c|c|c|c|c|c|c|}
\hline \multirow[b]{3}{*}{ Spring 2006} & \multirow{2}{*}{\multicolumn{4}{|c|}{ Transect 1}} & \multirow{2}{*}{\multicolumn{2}{|c|}{ Replicates }} & & & & \\
\hline & & & & & & & & & & \multirow[b]{2}{*}{5} \\
\hline & 1 & 2 & 3 & 4 & 5 & 1 & 2 & 3 & 4 & \\
\hline \multicolumn{11}{|l|}{ Ephemeroptera } \\
\hline Caenis & & & 1 & & & & & & & \\
\hline Hexagenia & & & 1 & & & & & & & \\
\hline Paracloedes & 1 & & 2 & 1 & 1 & & & & & 1 \\
\hline Stenonema & 6 & 5 & 10 & 10 & 10 & 14 & 5 & 7 & 10 & 7 \\
\hline Stenacron & 1 & & & 1 & & & 2 & 1 & & \\
\hline \multicolumn{11}{|l|}{ Odonata } \\
\hline Coenagrionidae & & & & & 1 & & & 1 & & \\
\hline Corduliidae & 1 & 1 & & & & & & & & \\
\hline \multicolumn{11}{|l|}{ Trichoptera } \\
\hline Cernotina & 18 & 2 & 9 & 6 & 9 & 5 & 7 & 5 & 8 & 7 \\
\hline Cyrnellus & 4 & 8 & 2 & & 1 & 2 & 1 & 1 & 2 & 3 \\
\hline Oecetis & & & & & & 1 & & & & \\
\hline $\begin{array}{l}\text { Rhyacophila } \\
\text { Coleoptera }\end{array}$ & & & & 1 & & & & & & \\
\hline \multicolumn{11}{|l|}{ Berosus } \\
\hline Dineutus & & 2 & 1 & & & & 1 & 1 & & 3 \\
\hline Gyretes & & & & & & & & 1 & & \\
\hline \multicolumn{11}{|l|}{ Diptera } \\
\hline Bezzia & & & 1 & & 1 & 1 & & & & \\
\hline Probezzia & & & 1 & & & & 1 & & 1 & 2 \\
\hline Chironomidae & 32 & 37 & 22 & 24 & 39 & 24 & 33 & 31 & 26 & 31 \\
\hline $\begin{array}{l}\text { Ostracoda } \\
\text { Gastropoda }\end{array}$ & & & & & 1 & 1 & & & 3 & \\
\hline Helisoma & & & & 1 & & & & & & \\
\hline Branchiura & & & & & & & 1 & & & \\
\hline Annelida & & & & & & & & & & \\
\hline Lumbriculus & & & & 1 & & 2 & 12 & 19 & 1 & 1 \\
\hline $\begin{array}{l}\text { Platyhelminthes } \\
\text { Pelecvnoda }\end{array}$ & & & & 1 & 1 & & & & & \\
\hline Corbicula & & & & & & 1 & 1 & & 1 & 1 \\
\hline Unionidae & & & & & & & & & & \\
\hline Hydrachnida & 4 & & 1 & 1 & & 1 & & & & 1 \\
\hline
\end{tabular}


Appendix Table 1c. Macroinvertebrates identified from Transect 3 and the Submerged Brine Pit in 3 replicates in Spring 2006.

\begin{tabular}{|c|c|c|c|c|c|c|}
\hline \multirow[b]{2}{*}{ Spring 2006} & \multirow[b]{2}{*}{1} & \multicolumn{2}{|c|}{ Transect 3} & \multicolumn{3}{|c|}{ Submerged Brine Pi } \\
\hline & & 2 & 3 & $\begin{array}{c}\text { Replicates } \\
1\end{array}$ & 2 & 3 \\
\hline $\begin{array}{l}\text { Collembola } \\
\text { Ephemeroptera }\end{array}$ & & & 1 & & & \\
\hline Paracloedes & 2 & & & & 2 & \\
\hline Stenonema & 3 & 2 & 7 & 4 & 4 & 2 \\
\hline $\begin{array}{l}\text { Stenacron } \\
\text { Odonata }\end{array}$ & & & 3 & & & \\
\hline $\begin{array}{l}\text { Coenagrionidae } \\
\text { Megaloptera }\end{array}$ & 1 & 1 & & 1 & & 1 \\
\hline $\begin{array}{l}\text { Sialis } \\
\text { Trichoptera }\end{array}$ & & & 1 & & & \\
\hline Cernotina & 8 & 7 & 12 & 8 & 16 & 10 \\
\hline Cyrnellus & 3 & 5 & & 3 & & 1 \\
\hline $\begin{array}{l}\text { Oecetis } \\
\text { Diptera } \\
\text { Bezzia }\end{array}$ & & & & & 1 & \\
\hline Ceratopogon & & & 1 & & & \\
\hline Probezzia & 3 & & 2 & & 1 & \\
\hline Chironomidae & 53 & 47 & 49 & 52 & 63 & 35 \\
\hline $\begin{array}{l}\text { Ostracoda } \\
\text { Gastropoda }\end{array}$ & 1 & & 1 & 1 & & \\
\hline $\begin{array}{l}\text { Helisoma } \\
\text { Annelida }\end{array}$ & & 2 & 1 & & & \\
\hline $\begin{array}{l}\text { Lumbriculus } \\
\text { Pelecvooda }\end{array}$ & 2 & 2 & 2 & 1 & 1 & 1 \\
\hline Corbicula & 1 & & & & & \\
\hline Hydrachnida & 7 & & 1 & 1 & 5 & \\
\hline
\end{tabular}


Appendix Table 1d. Macroinvertebrates identified from Transects 1 and 3 and the Submerged Brine Pit in 3 replicates in Fall 2006.

\begin{tabular}{|c|c|c|c|c|c|c|c|c|c|}
\hline \multirow[b]{2}{*}{ Fall 2006} & \multicolumn{3}{|c|}{ Transect 1} & \multicolumn{3}{|c|}{$\begin{array}{l}\text { Transect } 3 \\
\text { Replicates }\end{array}$} & \multicolumn{3}{|c|}{ Brine Pit } \\
\hline & 1 & 2 & 3 & 1 & 2 & 3 & 1 & 2 & 3 \\
\hline \multicolumn{10}{|l|}{ Ephemeroptera } \\
\hline Caenis & 3 & & & 3 & 6 & 5 & & & \\
\hline Hexagenia & & & & & & 1 & & & \\
\hline $\begin{array}{l}\text { Stenonema } \\
\text { Odonata }\end{array}$ & 1 & 2 & 2 & & 3 & & 8 & 7 & 5 \\
\hline Coenagrionidae & & 1 & & 1 & & & 2 & & 1 \\
\hline $\begin{array}{l}\text { Corduliidae } \\
\text { Trichoptera }\end{array}$ & & & & & & & & 3 & \\
\hline Cernotina & 33 & 33 & 42 & 11 & 7 & 6 & 7 & 10 & 4 \\
\hline Oecetis & 12 & 8 & 2 & 3 & 13 & 3 & 1 & 2 & \\
\hline Coleoptera & & & & & & & & & \\
\hline Berosus & & & 1 & & & & & & \\
\hline Diptera & & & & & & & & & \\
\hline Ceratopogon & & & & 2 & & & & 1 & \\
\hline Culicoides & & & & & & & & 1 & \\
\hline Odontomyia & & & & & & & & & 1 \\
\hline Probezzia & & 1 & & & & & 1 & & \\
\hline $\begin{array}{l}\text { Chironomidae } \\
\text { Ostracoda } \\
\text { Gastropoda }\end{array}$ & 37 & 127 & 71 & $\begin{array}{c}32 \\
2\end{array}$ & 52 & 62 & 20 & 25 & \\
\hline $\begin{array}{l}\text { Helisoma } \\
\text { Amphipoda }\end{array}$ & & & & & & & & 1 & \\
\hline $\begin{array}{l}\text { Hyallela } \\
\text { Annelida }\end{array}$ & & 1 & 1 & & & & & 2 & 1 \\
\hline $\begin{array}{l}\text { Lumbriculus } \\
\text { Gordiodea } \\
\text { Pelecypoda }\end{array}$ & 5 & 7 & 9 & $\begin{array}{c}11 \\
1\end{array}$ & 25 & 24 & 12 & 23 & 5 \\
\hline Corbicula & & & & & & 4 & & & \\
\hline Hydrachnida & 72 & 36 & & 59 & 19 & 27 & 13 & 39 & 2 \\
\hline
\end{tabular}

